\title{
ŬLIFAD
}

Papers of the

Investing in rural people 2019 Rural

Development Report

\section{Gender, rural youth and structural transformation: evidence to inform innovative youth programming}

by

Cheryl Doss Jessica Heckert

Emily Myers

Audrey Pereira

Agnes Quisumbing

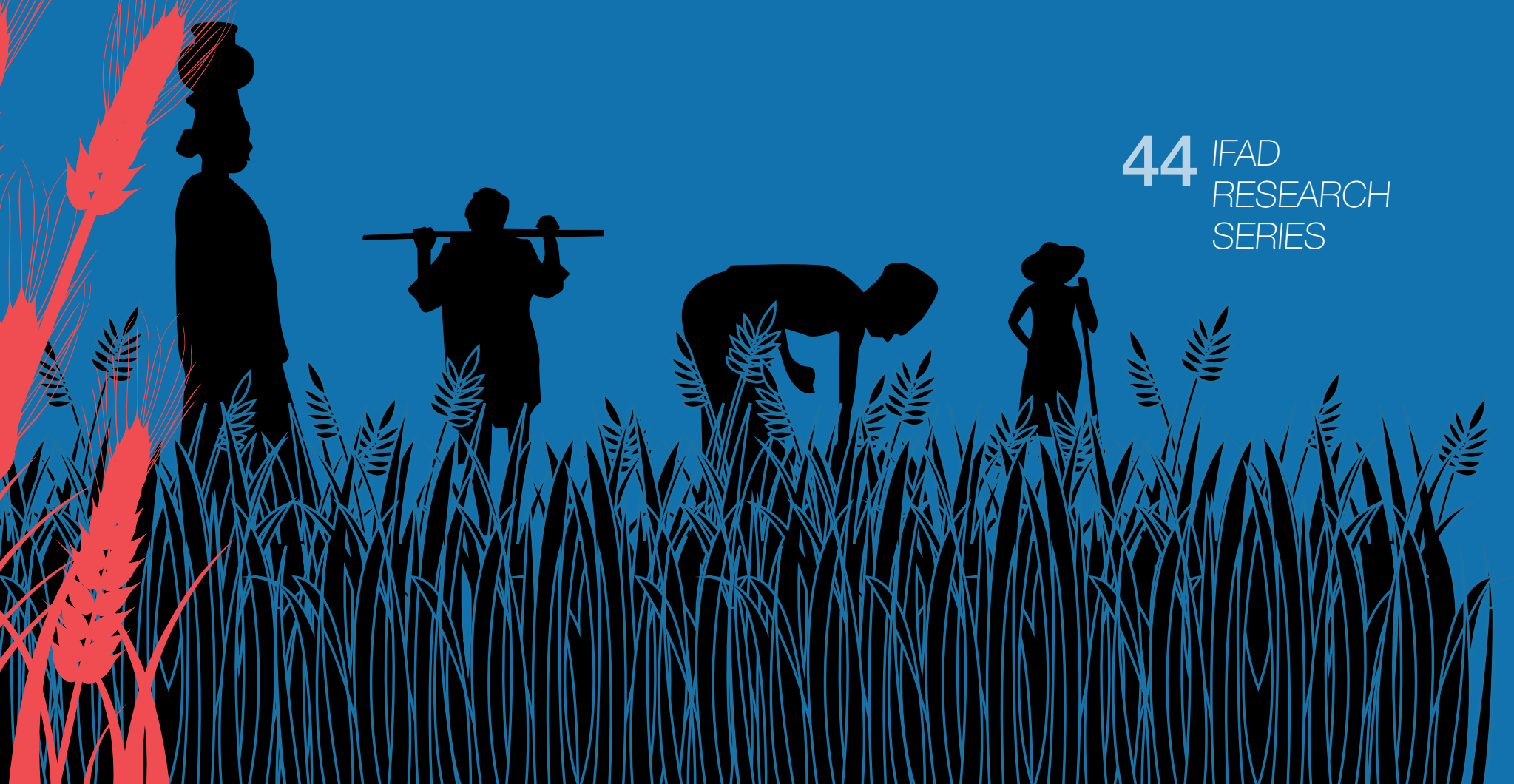


The IFAD Research Series has been initiated by the Strategy and Knowledge Department in order to bring together cutting-edge thinking and research on smallholder agriculture, rural development and related themes. As a global organization with an exclusive mandate to promote rural smallholder development, IFAD seeks to present diverse viewpoints from across the development arena in order to stimulate knowledge exchange, innovation, and commitment to investing in rural people.

The opinions expressed in this publication are those of the authors and do not necessarily represent those of the International Fund for Agricultural Development (IFAD). The designations employed and the presentation of material in this publication do not imply the expression of any opinion whatsoever on the part of IFAD concerning the legal status of any country, territory, city or area or of its authorities, or concerning the delimitation of its frontiers or boundaries. The designations "developed" and "developing" countries are intended for statistical convenience and do not necessarily express a judgement about the stage reached in the development process by a particular country or area.

This publication or any part thereof may be reproduced for non-commercial purposes without prior permission from IFAD, provided that the publication or extract therefrom reproduced is attributed to IFAD and the title of this publication is stated in any publication and that a copy thereof is sent to IFAD.

\section{Authors:}

Cheryl Doss, Jessica Heckert, Emily Myers, Audrey Pereira, Agnes Quisumbing

(c) IFAD 2019

All rights reserved

ISBN 978-92-9072-961-7

Printed December 2019 


\section{JँّIFAD}

Investing in rural people

Gender, rural youth and structural transformation: evidence to inform innovative youth programming

by

Cheryl Doss

Jessica Heckert

Emily Myers

Audrey Pereira

Agnes Quisumbing

\section{IFAD \\ RESEARCH SERIES}

This paper was originally commissioned as a background paper for the 2019 Rural Development Report: Creating opportunities for rural youth.

www.ifad.org/ruraldevelopmentreport 


\section{Acknowledgements}

This work was supported by funding from IFAD and the CGIAR Research Program on Policies, Institutions, and Markets (PIM), led by the International Food Policy Research Institute (IFPRI) under Flagship 5: Cross-cutting Gender Research and Coordination. The authors thank Aslihan Arslan, Constanza Di Nucci, Eva-Maria Egger, Anne Koerner, David Tschirley and Paul Winters for feedback on earlier drafts of this work.

This background paper was prepared for the Rural Development Report 2019 "Creating Opportunities for Rural Youth". Its publication in its original draft form is intended to stimulate broader discussion around the topics treated in the report itself. The views and opinions expressed in this paper are those of the author(s) and should not be attributed to IFAD, its Member States or their representatives to its Executive Board. IFAD does not guarantee the accuracy of the data included in this work. For further information, please contact ruraldevelopmenreport@ifad.org. IFAD would like to acknowledge the generous financial support provided by the Governments of Italy and Germany for the development of the background papers of the 2019 Rural Development Report.

\section{About the authors}

Cheryl Doss is an Associate Professor and Senior Departmental Lecturer in Development Economics at the University of Oxford. Her research focuses on issues related to assets, agriculture and gender with a regional focus on sub -Saharan Africa. Among her research projects, she co-leads the Gender Asset Gap Project, a large-scale effort to collect data and measure individual asset and wealth holdings for men and women in Ecuador, Ghana and Karnataka, India. This research examines best practices for collecting individual data on assets and also quantifies women's ownership of and control over productive assets. Currently, much of her work focuses on how to understand both joint and individual ownership and decision-making within rural households. She is the gender advisor for the CGIAR Research Program on Policies, Institutions, and Markets (PIM) led by the International Food Policy Research Institute (IFPRI). She has published widely in academic journals in economics, agricultural economics and development studies.

Jessica Heckert is a Research Fellow in the Poverty, Health, and Nutrition Division at IFPRI. Using both quantitative and qualitative methods, her research addresses questions related to better understanding the intersection of gender dynamics and health outcomes and the factors that lead to productive and healthy outcomes for young women and men during the transition to adulthood. She also works on the development of innovative and high-quality measures of women's empowerment as part of the Women's Empowerment in Agriculture Index team. She is a social demographer and earned a PhD in demography and human development and family studies from Pennsylvania State University in 2013.

Emily Myers is a research analyst in the Poverty, Health, and Nutrition Division at IFPRI. She is involved with qualitative research about gender and development. She also facilitates IFPRI's Gender Task Force, a cross-institutional group that supports researchers incorporating gender into their work, identifies knowledge gaps pertaining to gender, disseminates IFPRI's gender research, and links relevant gender policy research within CGIAR. She has a master's degree in public health from Emory University.

Audrey Pereira is a research analyst in the Poverty, Health, and Nutrition Division at IFPRI. She has a background in health economics related to maternal, child and adolescent health and nutrition, focusing on low- and middle-income countries. At IFPRI, she works on the Women's Empowerment in Agriculture Index and other research related to gender and development. Prior to joining IFPRI, she worked at the UNICEF Office of Research - 
Innocenti, the World Bank and Jhpiego. She holds a master of science in public health, concentrating on health systems and economics, from the Johns Hopkins Bloomberg School of Public Health.

Agnes Quisumbing, a senior research fellow at IFPRI, co-leads a research programme that examines how closing the gap between men's and women's ownership and control of assets may lead to better development outcomes. Her past work at IFPRI analysed the factors that enable individuals, households and communities to move out of poverty over the long term, and how resource allocation within households and families affects the design and outcome of development policies. Her research interests include poverty, gender, property rights and economic mobility. She has led a study on intrahousehold allocation and development policy in Bangladesh, Ethiopia, Guatemala and South Africa. She has also worked on women's land rights in Ghana, the Philippines and Sumatra, Indonesia. She has been involved in longitudinal studies in Bangladesh, Guatemala and the Philippines, and is currently engaged in impact evaluations of agricultural development programmes, focusing on their impacts on gender asset inequality, in South Asia and sub-Saharan Africa. A citizen of the Philippines, Quisumbing joined IFPRI in 1995. She received her PhD and MA in economics from the University of the Philippines, Quezon City, and her A.B. in economics from De La Salle University in Manila. Before joining IFPRI, Quisumbing worked at the University of the Philippines (Diliman and Los Baños), the World Bank, Yale University and the International Rice Research Institute. 


\section{Table of contents}

1. Introduction 1

2. Conceptual framework 1

3. Evidence on the gendered resources, constraints and opportunities facing rural youth $\quad 4$

3.1 Land 5

3.2 Education $\quad 5$

$\begin{array}{ll}\text { 3.3 Social and political capital } & 6\end{array}$

$\begin{array}{ll}3.4 \text { On-farm and off-farm employment } & 6\end{array}$

$\begin{array}{ll}3.5 \text { Self-employment and entrepreneurship } & 7\end{array}$

$\begin{array}{ll}3.6 \text { Migration } & 7\end{array}$

$\begin{array}{ll}3.7 \text { Summary of existing evidence } & 8\end{array}$

4. Data analytical approach 9

5. Results 10

$\begin{array}{lr}5.1 \text { Household context } & 10\end{array}$

$\begin{array}{ll}5.2 \text { Assets of rural youth } & 12\end{array}$

$\begin{array}{ll}5.3 \text { Livelihoods and current activities } & 14\end{array}$

$\begin{array}{ll}5.4 \text { Youth transitions over time } & 16\end{array}$

$\begin{array}{ll}5.5 \text { A summary of gender issues by ST-RT category } & 19\end{array}$

6. Gender-sensitive programming for rural youth: lessons learned from impact evaluations of $\begin{array}{ll}\text { youth-oriented interventions } & 21\end{array}$

$\begin{array}{ll}6.1 \text { Vocational and skills training } & 21\end{array}$

$\begin{array}{ll}\text { 6.2 Credit and cash grants for entrepreneurs } & 23\end{array}$

6.3 Programmes potentially affecting adolescents and their families 25

7. Conclusions 26

Tables and figures $\quad 28$

References $\quad 34$

$\begin{array}{ll}\text { Appendices } & 39\end{array}$ 


\section{Abstract}

The transition to adulthood is marked by interrelated changes in the areas of education, employment and family formation. Using frameworks on gendered transitions to adulthood and links between assets and livelihoods, we analyse nationally representative, sex-disaggregated data from 42 countries to characterize rural youths' transition to adulthood by gender and according to a four-category typology of low and high levels of structural and rural transformation. Overall, we find that young women and men experience the transition to adulthood differently according to the structural and rural transformation classification of the countries where they live. Across all structural and rural transformation categories, young women are more likely to be married and living with their spouses or in-laws, less likely to be in school or employed, and less likely to own land solely. Gender gaps in secondary school education favour young women only in countries with higher levels of structural and rural transformation, and favour young men in the other three categories. Moreover, a larger proportion of young women than young men are not in education, employment, or training (NEET), but many NEET youth, especially young women, have transitioned into domestic and reproductive roles (i.e. are more likely to be married and/or have children.) Additionally, we review impact evaluations of interventions targeting youth. We find limited evidence on the gendered impacts of such programmes, and these programmes seldom consider how constraints differ for young men and young women. Addressing gaps in programmes and building an evidence base on the gendered impact of interventions can provide insights into how gender roles can simultaneously limit options and offer opportunities to young rural women and men in the context of structural and rural transformation. 


\section{Introduction}

Although there is increasing policy interest in rural youth, many efforts do not simultaneously consider how gender - the socially determined roles of young men and young women - affects transitions into adulthood. The transition into adulthood involves preparation for adult roles, through investments in schooling and health, and the actual transition into adult roles, through the transition to work, transition to citizenship or community engagement, the transition to marriage and the transition to parenthood (National Research Council and Institute of Medicine, 2005). These transitions are interrelated, and decisions made by young people and their families are important, affecting not only the young person's own well-being throughout the life course but also the well-being of future generations.

Between the ages of 15 and 24 years, rural youth are deciding whether to continue studying, to leave school, to leave their natal households, to work, to become engaged in their communities, to form unions, and to have children - and these experiences differ vastly for young men and young women. Many doors open to boys as they become men, though in many societies, windows of opportunities begin to close for girls. As boys and girls enter adolescence, they bring with them the investments made in them since childhood. These may include investments in their human capital - education, health and nutritional status - and in their social capital - the networks that facilitate opportunities for learning, employment and status attainment. Opportunities to accumulate both social and human capital are highly gendered, and thus male and female youth have often accumulated vastly different amounts of these resources. Although they may not yet be owners or holders of physical assets, they may expect to inherit them, or may work to acquire them as they grow older. Young women may stop schooling earlier or leave the labour force to form a union (whether marriage or informal); some begin childbearing.

This background paper aims to: (1) present a framework for understanding the gendered transitions to adulthood, focusing on how human, physical and other assets of young men and women shape their livelihood strategies; (2) explore how gender roles affect the resources, constraints and opportunities that rural youth face, based on the existing literature; (3) characterize what young rural women and men are doing in the transition to adulthood, using nationally representative datasets from many countries, classified according to their levels of structural and rural transformation; (4) review rural youth interventions with a gender lens, to identify elements of appropriate and gender-sensitive investments and supportive programmes; and (5) identify the gaps in knowledge and practice, and how we can close them.

\section{Conceptual framework}

The empirical work in this paper is grounded in two complementary conceptual frameworks: (1) the transitions-to-adulthood framework developed by the National Research Council (US) Panel on Transitions to Adulthood in Developing Countries; and (2) the Gender, Agriculture, and Assets Project (GAAP) framework that links assets, livelihoods and well-being outcomes.

The transitions-to-adulthood framework (National Research Council and Institute of Medicine 2005) focuses on young people in developing countries and their entry into adult roles in the interrelated areas of work, citizenship and family (marriage and parenthood). This framework divides contexts into three levels: the changing global context, the changing national context and the changing local community context. All three are undergoing a process of widespread structural transformation, making this a useful framework for embedding the lives of rural youth in the context of structural transformation, which is the focus of this paper. 
Three aspects of this framework are noteworthy: (1) it emphasizes change - in the global and immediate environments, in young people themselves and in the transition process; (2) although the focus is the entry of young people into adult roles in their own societies, the framework acknowledges their transitions are shaped by the contexts in which their daily lives are embedded; (3) the framework highlights the interlinkages between the context and individual behaviour, and pays special attention to changes in the individual resources and attributes during transition (health/reproductive health, human capital, sense of agency, beliefs, attitudes and perceptions) and changes in the timing, sequencing, duration and nature of transition to adult roles. The framework emphasizes "changes in the acquisition of various kinds of attributes or capabilities and in orientation towards the changing structure of opportunity" (Ibid., 35), which are all relevant to changes in the timing and nature of the transition to adulthood. Finally, the framework recognizes that changes in global, national and local environments will have different implications for young men and women - transitions to adulthood are gendered and young people themselves undergo various transitions at different ages depending on culture and context.

The GAAP conceptual framework, which is inspired by the Sustainable Livelihoods Framework (Bebbington, 1999; DFID, 2001), takes the gendered nature of use, ownership and control of assets as a starting point (Meinzen-Dick et al., 2011). Households and individuals hold a range of tangible and intangible assets: (1) natural resource capital (land, water, trees); (2) physical capital (houses and vehicles); (3) human capital (education, knowledge, skills); (4) financial capital (savings, credit); (5) social capital (membership in organizations or groups); and (6) political capital (citizenship and participation). These assets provide means for people to earn a living, give individuals the capability to act (agency) and give meaning to people's lives (Bebbington, 1999). Men and women - young or old - hold different types of assets and may do so individually or jointly. Human capital embodied in a person's schooling or experience is clearly an individual asset while others, such as land or savings, can be held either jointly or individually. Others are created by association with others (social capital).

In adapting the GAAP conceptual framework to the analysis of young women and men in their transition to adulthood, we look at the pathways through which assets influence young men's and women's transition to adulthood and the way these transitions, in turn, affect their assets, their livelihoods and their well-being (see below). The GAAP framework shows the strong link between assets and well-being and the ways gender relations influence how young men and women experience constraints and opportunities. Each component of the framework is shaded to remind readers that these assets and activities may be individual or joint. Joint assets and activities may involve spouses, a parent and child, siblings, another household member, or someone outside the household.

The framework includes the following elements:

Context. Ecological, social, economic and political conditions affect young men and women differently. Economies undergoing rapid structural transformation with relatively egalitarian gender norms may be more able to absorb young women into the wage sector compared with a similar economy with restrictive gender norms. The transitions-to-adulthood framework emphasizes the role of different contexts in shaping the links leading from assets to livelihoods to well-being. The household context whether youth are children or in-laws of the head of household or are household heads themselves is especially relevant in their transition to adulthood.

Assets. Access to and control over assets are key determinants of individual agency. Within a household, some assets are held or used by women, some by men, and some jointly. Although in most countries the majority of natural, physical and financial assets are held by men, young men frequently do not hold assets until they form a separate household (for example, when they marry). In some cases, they may be expected to accumulate assets to demonstrate that they are eligible to marry. Young women typically own fewer of these assets than men. However, in contexts where 
marriage confers property rights to both spouses, women who marry young may acquire joint assets earlier than men. The gender gaps tend to be smaller for human capital in comparison with natural and physical capital.

Livelihood strategies. Stocks of assets, in turn, affect livelihood strategies, which involve decisions about how to invest assets to generate returns (income, food and so on). Whether young men and women work on or off the farm, become entrepreneurs or migrate is conditioned by their stocks of assets and their strategies to use them. Some assets can be built or enhanced, as represented by the reverse arrow from Livelihood Strategies to Assets in Figure 1. These livelihood strategies - farm and off-farm work, entrepreneurship and migration - may differ for young men and young women.

Shocks. Negative and positive shocks (unanticipated events) can be caused by weather, disease, conflicts, thefts or policy changes, among others. Some shocks are specific to a household (the death of an income earner), some to individuals (divorce or abandonment) and still others affect entire regions. Young men and women experience shocks differently, depending on their resources, roles and responsibilities, and may be more vulnerable owing to their youth, lack of experience and lack of legal status, particularly for the younger cohort. In addition, they have different capacities to withstand shocks. For example, families may be more likely to keep girls out of school when they lack money for school fees or when additional labour is needed at home.

Full incomes. Full income is the total value of products and services produced by household members, including that consumed within the household and that traded or sold. It also includes the value of time spent on domestic responsibilities and childcare, even if unpaid. Household members differ in their contributions to household income and in their control over how that income is used. Because young women often work as unpaid family workers, or do domestic chores and care for younger children, their contribution to the household is often undercounted unless a full income measure is used.

Consumption and savings. Often men and women spend money differently, with women spending a higher proportion of the income they control on food, health care and children's education. Women's, men's and joint income - as well as income contributed by young people within the household - can be used for different types of investment. Savings are the balance of income that is not consumed. Both saving and consuming can affect asset accumulation or loss. Consumption of nutritious food, clean water and adequate shelter contributes to human capital. Individual consumption and savings will be influenced by the amounts of income that individuals control. Youth, especially young women, may earn relatively little and control only a portion of their earnings.

Well-being. Measures of well-being range from those associated with consumption (education and food security) to those that are less tangible (self-esteem, empowerment and status). Assets positively impact well-being by (1) increasing status and empowerment; (2) providing opportunities to pursue various livelihood strategies; (3) providing a buffer against shocks; and (4) strengthening household members' positions in the household and the broader community. 


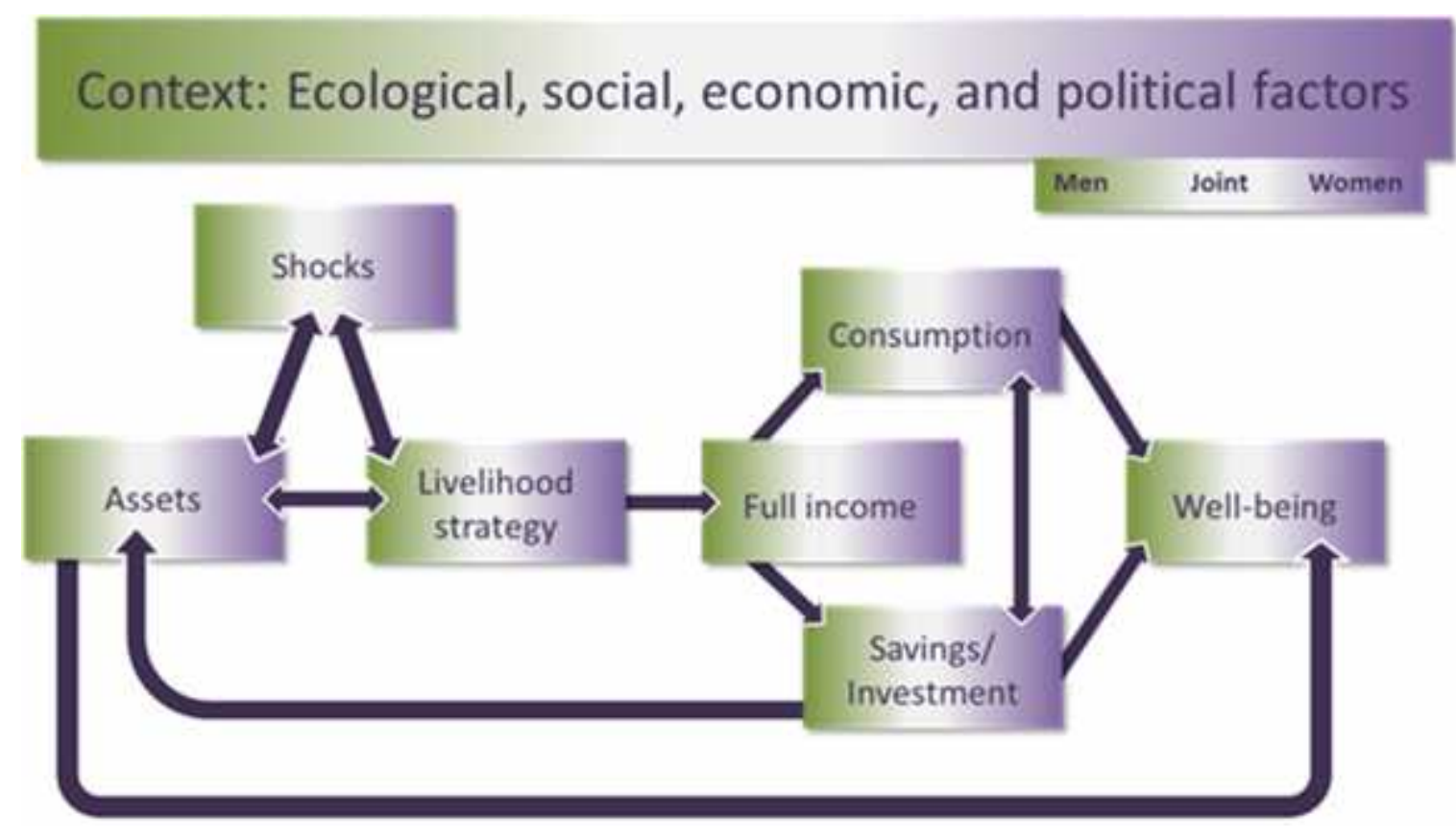

Source: Meinzen-Dick et al. (2011)

\section{Evidence on the gendered resources, constraints and opportunities facing rural youth}

The accumulation of assets and pursuit of livelihood strategies are the two components of the conceptual framework that are key to understanding the constraints and opportunities facing rural youth. Young men and women may face different constraints and opportunities in using these assets for their livelihoods. Though other syntheses of livelihood and/or asset acquisition strategies in rural contexts exist, few examine the overlaps between youth and gender and these themes. This review addresses this knowledge gap through a review of the evidence specific to rural youth. Although this review is not a systematic review, it employed similar principles in identifying papers for inclusion, using pre-specified selection criteria to screen papers for subsequent synthesis. Eligibility was determined by the following criteria: (1) English-language, peer-reviewed publications and working papers; (2) published between 2000 and 2017; (3) conducted in low- and middle-income countries; (4) using quantitative, qualitative, mixed method, observational or impact assessment methodologies; and (5) focusing on male and female youth aged 15-24. These criteria were applied to three major topics: the resources, constraints and opportunities of rural youth. Resources included different forms of assets: land (natural capital), physical capital, and financial, social and political capital; constraints and opportunities included farm and non-farm employment, self-employment, entrepreneurship and migration. Because other chapters in the 2019 Rural Development Report deal with migration and nutrition of rural youth, this was not a primary emphasis of our search; also, because IFAD does not focus on human capital investments such as schooling and health, we did not include these topics in our review. Education eventually emerged as an important correlate of some opportunities (notably employment and migration). Google Scholar was searched in March and April 2018, and abstracts were examined against the pre-specified inclusion criteria. Additional articles were identified from the reference lists of these articles and through the authors' prior familiarity with research on rural youth. The review identified a total of 40 papers. Five papers were about land; three were about education; 
five were about social and political capital; four were about farm and non-farm employment; 11 were about self-employment and entrepreneurship; and 12 were about migration (appendix 1). The country in which the research was conducted, publication type, methodology, sampling strategy and size, and principal findings were noted for each paper. Since the papers included represented a variety of research methodologies and geographic contexts, the review used a narrative approach to synthesize findings.

The small number of papers included in our review suggests that, while there are extensive literatures on these topics, very few focus on rural youth, and even fewer provide a gender analysis. The relatively small number of countries covered by these studies makes an analysis of multi-country data essential to provide a broader perspective (see section 4). The literature review, therefore, should be interpreted as providing an introduction to the gendered opportunities and constraints experienced by rural youth.

\subsection{Land}

Only a small proportion of the work on land (a type of natural resource capital) analyses the data by both sex and age. Only recently has land ownership data been collected at the individual, rather than the household, level. These data have been used to analyse landownership patterns by sex (Doss et al., 2015; Kieran et al., 2017) but rarely by age. One analysis of four countries in Asia that looks at differences by age finds that the probability of being a landowner is higher for the 20-29 age group in Bangladesh and Vietnam compared with the 18-20 age group, owing to marriage and the formation of new nuclear households in the older age group. In many cultures, marriage signals the beginning of a new family unit, and often (but not always) includes the transfer of land from parents to child. The differences between these age groups are not statistically significant in Tajikistan and Timor-Leste (Kieran et al., 2017). While youth may not yet own land, their expectations of inheritance will differ by gender. For example, while 40 per cent of Burundian young men expect to inherit land from their family, only 17 per cent of young women have similar expectations (Berckmoes and White, 2014). Access to land may be related to other outcomes for youth. In an analysis of Ethiopia, Kosec et al. (2018) find that larger expected land inheritances for youth (defined as age 15-34) decrease the likelihood of permanent migration. Inheriting more land also leads to a higher likelihood of employment in agriculture and a lower likelihood of employment in the non-agricultural sector. These patterns are driven largely by the behaviour of male youth; land inheritance is not a significant predictor of permanent migration by women. Also, while larger inheritances predict a greater likelihood of working in agriculture for both men and women, the magnitude of the effect of inheritance is statistically larger for men, and the lower likelihood of working in a non-agricultural sector is statistically significant only for men.

\subsection{Education}

Much more evidence is available on human capital accumulation, and this information is frequently disaggregated by sex and age. Human capital includes education, nutrition and health. Education is key to taking advantage of many opportunities available to rural youth, but in many contexts, girls remain disadvantaged in this area, although gender gaps in education are closing in most places (see Demographic and Health Survey (DHS) analyses below). Parental aspirations may favour boys with respect to schooling (see Favara, 2017 for Peru), while gender priming in terms of expectations may worsen educational outcomes for girls (Mukherjee, 2015 for India), but the effect of aspirations is context specific. Expectations about girls' contributions to household work may also limit their schooling. In rural Ghana, for example, mobility constraints and household work burdens were found to have more negative implications for the schooling outcomes of girls compared with boys (Porter et al., 2011). 


\subsection{Social and political capital}

Youth groups may play an important role in facilitating the building of social and financial capital. The BRAC model in Uganda and Tanzania, for example, provides young women with programming about healthy education, life skills and financial literacy, and it offers microcredit opportunities (Banks, 2015). Such programmes aim to enhance health, educational and economic outcomes - and evidence suggests that well-run youth groups do achieve these aims. Additionally, social networks offered through youth groups help young women foster self-confidence, develop meaningful peer relationships and share a sense of solidarity (lbid.). However, lack of community buy-in, inadequate funding, poor mentorship and bad management may undermine the success of youth groups (lbid.).

Political participation is widely recognized as an important catalyst of change in rural development, particularly when youth are engaged. However, gender disparities in political participation may limit progress in this area. Several studies show that women's participation often lags behind that of men; for example, a survey from India found that while 68 per cent of young men voted in the most recent election, only 57 per cent of young women did (Acharya et al., 2010). A 2011/2013 Afrobarometer survey found that youth participation in protests is lower among young women (8 per cent) than young men (13 per cent) (Lekalake and Gyimah-Boadi, 2016). The same survey found that young women are also significantly less likely than young men to report having an interest in politics (48 per cent versus 60 per cent) or discussing it with family and friends (61 per cent versus 74 per cent) (lbid.). However, two separate studies - both from Africa - found no gendered differences in preferences for democratic systems of governance (Resnick and Casale, 2011; Keulder and Spilker, 2002). A study from India found that political participation is associated with age, marital status and rural residence for men and women (Acharya et al., 2010). In India, economic status is also positively related to political participation, though only for young women relative to young men (lbid.).

\subsection{On-farm and off-farm employment}

Rural young men and women face numerous challenges as they take a more active role in pursuing livelihoods. Both farm and non-farm work offer rural youth important opportunities. Regardless of sector or country context, young men are much more likely to be employed than young women (Fares et al., 2007). Among youth who are not employed, young men tend to become discouraged and cease their job search without taking on additional activities, meaning that their full incomes decrease, while unemployed young women engage in non-market activities, such as uncompensated household work (Ibid.). Additionally, education may determine who seeks off-farm opportunities. To an extent this may be driven by the skills needed in off-farm activities, but education may also transform perceptions of ideal work.

Whether youth work or not, and their experiences working in both on-farm or off-farm activities, is governed by social norms. For example, on Ethiopian farms, ploughing, sowing seeds and threshing are seen as men's work, while women tend household gardens, clean animal pens and perform the milking (Gella and Tadele, 2015). Though women may work alongside men weeding and harvesting, they are often regarded as "helpers" rather than workers (lbid.). Norms also shape preferences about on-farm and off-farm work. In Nigeria, young women prefer off-farm work, because they can control their earnings; whereas when working on the family farm, other household members control the income (Bryceson, 2002). Workplace safety is often a more substantial concern for female youth, and sexual assault is a common reason why they leave their jobs, as documented in rural Malawi (Hajdu et al., 2013). 


\subsection{Self-employment and entrepreneurship}

Among off-farm work activities, self-employment or entrepreneurship is a significant youth livelihood strategy. Youth entrepreneurship has many benefits, including creating employment, increasing resilience and utilizing innovation (Chigunta et al., 2005; White and Kenyon, 2007). Although the proportion of entrepreneurs who are women is increasing, men are still more likely to be involved in entrepreneurial activities than women (Vossenberg, 2013). Globally, 52 per cent of entrepreneurs are men and 48 per cent are women (Ibid.). However, the patterns vary across countries, possibly reflecting underlying gender norms within those countries. In Jordan, for every female entrepreneur there are four male entrepreneurs, while in Brazil, there is gender parity (Kelley et al., 2011). The increase in young female entrepreneurship may continue, as some studies find that young women prefer non-farm work and have higher aspirations to start their own businesses than young men (Chigunta et al., 2005).

Many barriers to starting and running businesses are deeply rooted in gender norms. Women, including young women, are hindered by domestic work/childcare burdens, lack of family support, greater risk aversion, negative attitudes towards women in business, sexual harassment, lack of proof of identity, and limited access to financial services (Aggarwal and Klapper, 2013; Ahaibwe and Kasirye, 2015; Elder and Kring, 2016; Mehta and Mehta, 2011; Johnson et al., 2013; White and Kenyon, 2007). In Uganda, young women's access to credit markets is limited because they are less likely than young men to own assets or the property required as collateral for loans (Ahaibwe and Kasirye, 2015). Given that female youth are also more likely to be involved in primary agricultural production or work as unpaid family workers, banks may consider them risky and not creditworthy. Additionally, distances to financial institutions may raise safety concerns, and restrictions on young women's mobility may further limit access to services (Sykes et al., 2016). Women are also likely to bear a disproportionate burden of financial illiteracy, lacking the knowledge, skills and information required to access financial services (Aliero and Ibrahim, 2013). Some of these barriers are structural, and when barriers to accessing financial services are addressed, for example in the YouthSave project implemented in Colombia, Ghana, Kenya and Nepal, female youth save as much or more than male youth (Johnson et al., 2013).

\subsection{Migration}

Migration provides opportunities for both male and female youth. It is driven both by the lack of rural opportunities and perceived potential opportunities elsewhere. Traditionally, migration has been framed in terms of labour opportunities. Increasingly, evidence suggests that youth also migrate to increase their human capital (education and training) as part of an extended period of parental investment (Heckert, 2015; McKenzie, 2008). In addition to the structural drivers of migration, youth migration is also embedded in the coming-of-age experience and offers youth the opportunity to earn and manage income and make decisions independently from their natal households. Female youth, in particular, may appreciate these opportunities, since they often do not have them in their home communities (Hertrich and Lesclingand, 2013). Whether migration is more common among male or female youth varies across contexts. Perhaps more important than the absolute numbers is the fact that the drivers, experiences and expectations of young migrants are highly gendered, and female youth experience migration in terms of both departure from (e.g. earning wages, living apart from family members) and continuity with (e.g. gender-specific employment, filial piety by providing monetary support) traditional gender roles (Castellanos, 2007; Chiang et al., 2013). The different migration experiences of male and female youth further differentiate the gendered accumulation of assets. 
Female youth may experience unique migration obstacles. Their more intensive household labour contributions may tie them to their natal homes (Hsin, 2005), but also make them ideal candidates to reside with urban families and provide domestic service (Moya, 2007). Families may be less willing to support female youth in education and labour migration if they perceive that the labour market will not reward young women (Buchmann, 2000). Evidence from Haiti has found that female youth migrants are less likely to receive financial support from their natal household than male youth migrants (Heckert, 2015).

Labour opportunities for migrants are often highly gendered. In China, young male migrants are formally channelled into manual or construction work, and female migrants into factory work, domestic work and the service industry (Fan, 2003). In other contexts, young men are often sought for mining or labour-intensive agriculture, while the growth of the service sector and the demand for domestic labour as more urban women enter the formal workforce creates opportunities for young, female rural-tourban migrants (Moya, 2007; Palmer, 2009). The accumulation of resources and the development of autonomy that occurs alongside migration may alter transitions in other domains. Migration may allow female youth to accumulate more resources prior to marriage and help them delay marriage. Such delays may have a large impact on the transition to adulthood, especially in countries such as Mali where the early marriage of girls is common (Hertrich and Lesclingand, 2012).

In addition to those youth who migrate, youth may also be left behind by migrant parents or spouses, providing them with opportunities to access land for farming. The outmigration of rural men may lead to the reallocation of household responsibilities, which may increase young women's participation in agricultural or other rural production activities (Fan, 2003). The outmigration of rural youth may have different effects on those left behind, depending on the gendered division of labour in agriculture, which varies by culture and context. Mueller et al. (2018) show that, while migration of any child of the household head could potentially create labour shortages, the migration of the household head's sons produces a greater burden, particularly for female heads/spouses (in Ethiopia) and brothers (in Malawi). Because of the labour shortages created at home, migration may not result in net gains to the family. In Ethiopia, gains from migration in the form of increased total net income justified the increased labour efforts, while in Malawi, households substituted hired labour for migrant family labour at the expense of total household net income.

\subsection{Summary of existing evidence}

In examining the existing literature on the gendered resources, constraints and opportunities facing rural youth, we are struck by the sparseness of literature that focuses on gender and rural youth. With the exception of education (human capital), there is limited work on the gendered accumulation of resources among youth. From the existing literature on asset accumulation, it is important to note that expectations of inheritance may be important, in addition to actual assets owned, and that some assets (e.g. land) may be acquired as a part of the marriage processes. Young men and women in rural areas engage in a variety of employment activities, both on and off farms. In some contexts, offfarm entrepreneurial work may be one way for young women to maintain control over their earnings. Young women's engagement in off-farm entrepreneurial activities is increasing, but their full involvement may be constrained by access to assets and credit. Both young men and women migrate, many of them from rural to urban areas, and are affected by the migration of other household members. Recognizing the outmigration of rural youth is important for how we interpret data on a cross-section of youth currently living in rural areas. 


\section{Data analytical approach}

We draw on multiple nationally representative datasets to analyse the household context, the livelihoods and current activities and assets of rural male and female youth. Although the definition of youth varies across countries, we standardize our definition of youth as those between 15 and 24 years of age. Since 18 is the age of majority in most countries, we also analyse two groups of youth, those aged 15-17 and those aged 18-24. We limit our samples to youth who currently live in rural areas, as defined by each country's national statistics office at the time of the survey. In brief, countries are classified into categories depending on the levels of their structural and rural transformation. The World Development Indicators (WDI) were used to construct indicators of the levels of structural and rural transformation, with the non-agricultural value-added share of GDP as the indicator for structural transformation (ST) and the agricultural value added per worker (constant 2010 US\$) as the indicator of rural transformation (RT). High and low classifications for typologies are defined by the global mean of ST and the global median of RT. Weighting is based on the survey weights provided by the survey designers, which are then adjusted to account for the population size in each group according to the ST-RT typology. All estimates are pooled according to the ST-RT typology and weighted.

To describe the current household context of rural youth, their employment patterns, education, and land and housing ownership, according to the ST-RT typology, we use data from countries where a DHS survey has been conducted since 2010, excluding countries that are not included in the typology (ICF International, 2018). ${ }^{1}$ The high structural and high rural transformation category (high ST-high RT) includes the following datasets: Colombia 2015, Dominican Republic 2013, Egypt 2014, Ghana 2014, Guatemala 2014/15, Honduras 2011/12, Indonesia 2012, Kyrgyz Republic 2012, Namibia 2103, Peru 2012 and Philippines 2013. The high structural and low rural transformation category (high STlow RT) includes the following datasets: Bangladesh 2014, Cameroon 2011, Gambia 2013, India 2015/16, Lesotho 2014, Senegal 2016 and Zambia 2013/14. The low structural and high rural transformation category (low ST-high RT) includes Cote d'Ivoire 2011/12, Chad 2014/15, Nigeria 2013, Pakistan 2012/13 and Tajikistan 2012. The low structural and low rural transformation category (low ST-low RT) includes Afghanistan 2015, Benin 2011-12, Burkina Faso 2010, Burundi 2010, Cambodia 2014, Ethiopia 2016, Guinea 2012, Kenya 2014, Malawi 2015/16, Mali 2012/13, Mozambique 2011, Myanmar 2015/16, Nepal 2016, Niger 2012, Rwanda 2014/15, Sierra Leone 2013, Tanzania 2015/16, Togo 2013/14 and Uganda 2016. Data from Bangladesh, Egypt, Tajikistan and Peru are included only for estimates of the proportion of youth who ever married, as there is no data on male youth for other outcomes.

Three datasets contain information on whether youth are in possession of a national identity card: the 2012/13 DHS for Pakistan, where identity cards are made available and compulsory at age 18; the 2014 Multiple Indicator Cluster Survey (MICS) for the Dominican Republic, where identity cards are made available starting at age 16; and the 2012 Housing and Population Census for Bolivia, where identity cards are made available even to children and are compulsory at age 18 (Oficina Nacional de Estadística and UNICEF, 2014; National Institute of Statistics in Bolivia, 2012).

Two datasets disaggregate asset ownership by individual: the 2011/12 Ethiopia Rural Socioeconomic Survey and the 2009/2010 Ghana Socioeconomic Panel Survey (Ethiopia Central Statistical Agency and World Bank, 2011/12; ISSER and Economic Growth Center, 2009/10). We calculate the mean number of agricultural assets, non-agricultural assets and consumer durables. In Ghana, we also

\footnotetext{
${ }^{1}$ The following countries for which DHS data exist, but are not included in the typology, are dropped: Yemen, Haiti, Jordan, Angola, the Comoros, Republic of the Congo, Democratic Republic of the Congo, Gabon, Lesotho, Liberia and Zimbabwe.
} 
calculate the mean number of chicken/poultry and the mean number of non-poultry livestock owned. A full list of items in each category is provided in table 2 . All country and survey information is available in appendix 2 .

\section{Results}

This section presents our findings from the analysis of the DHS datasets, using the ST-RT typology. We also point out some features of the regional distribution of countries across these categories, where we use regional distribution as a rough proxy for social, cultural and gender norms. The high ST-high RT countries, for example, have many countries from Latin America and the Caribbean, and two South-East Asian countries (Indonesia and the Philippines) - all of which have relatively egalitarian gender norms and generally strong property rights for women. Bangladesh and India (two South Asian countries with more restrictive gender norms and patriarchal traditions) are two countries with large populations in the high ST-low RT category together with four African countries. It is noteworthy that the low ST-low RT category is dominated by African countries (15 countries) and four countries that have a history of recent or ongoing political unrest in South Asia (Afghanistan, Nepal) and South-East Asia (Cambodia, Myanmar). We have relatively few countries in the high ST-low RT and the low ST-high RT categories.

In the following analysis of ST and RT and gender differences among rural youth, it is important to keep in mind that ST and RT can interact with gender norms, and the assumption should not be that ST and RT are driving gender differences. One could hypothesize, for example, that returns to women's education would be higher in high ST countries, which could both benefit from more egalitarian norms that encourage investments in women's education, as well as be reinforced by an increased demand for educated labour. Whether high levels of RT similarly encourage the participation of female versus male youth depends on the gender division of labour in agriculture and the structure of property rights in a specific context.

\subsection{Household context}

Across all ST-RT categories, nearly all sons, and a large share of daughters, live with parents; female youth are ever married at rates three to five times higher than male youth.

The vast majority of male youth are sons of the household head in all four ST-RT categories (figure 2, table 1). A notable proportion have also become heads of household in the high ST-high RT and low ST-high RT typologies. Around half of female youth are daughters of the household head in three STRT categories, but in the low ST-high RT category, only one quarter of female youth are daughters of the household head. Among female youth, many have also transitioned into being spouses or daughters-in-law of the household head. The result for the low ST-high RT category, which has a relatively small number of countries, may be driven mostly by the larger populations of Nigeria and Pakistan.

These patterns of household residence are closely tied to marriage patterns (figure 3). Across the four categories, almost none of 15-17-year-old male youth have ever married, whereas a larger proportion of female 15-17-year-olds have married in all four categories (figure 4, appendix 3). The low ST-high RT category had the largest share of ever-married 15-17-year-olds (20 per cent). The obligations tied to early marriage may limit the potential of female youth to accumulate resources (human and physical). Across all four typologies, the proportion of female youth aged 18-24 who have ever married is around 60 per cent. Young men aged 18-24 do marry, but a lower proportion are married compared with young women (approximately 20 per cent). Thus, it is remarkable that, regardless of ST-RT category, a higher proportion of female youth are married relative to male youth. 
Figure 2. Distribution of rural youth (aged 15-24 years) by relationship to the head of household, by gender and structural transformation typology

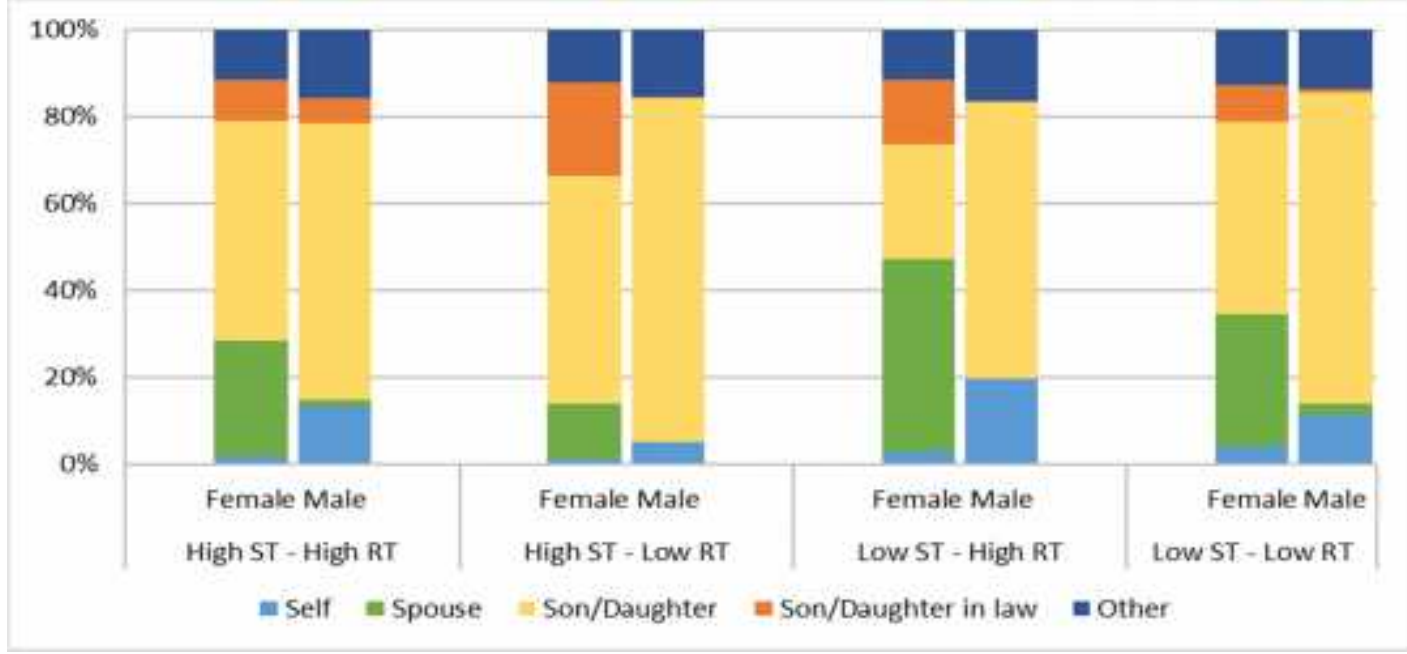

Note: ST: Structural Transformation; RT: Rural Transformation

Figure 3. Per cent of ever-married rural youth (aged 15-24 years), by gender and structural transformation typology

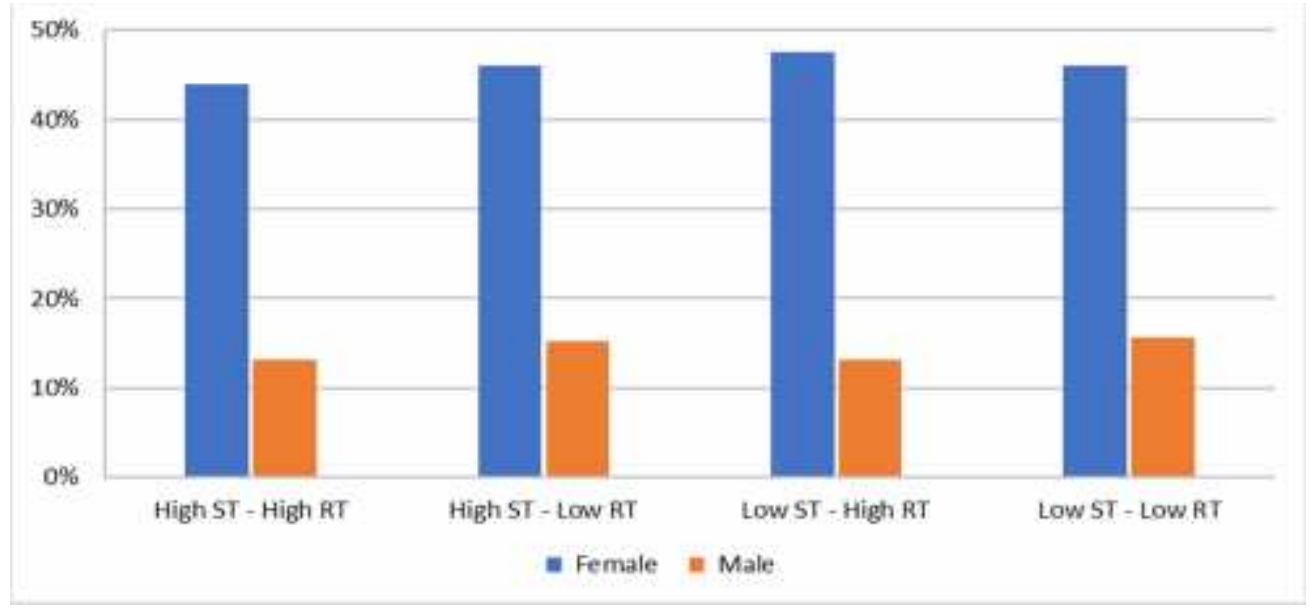

Note: ST: Structural Transformation; RT: Rural Transformation

Figure 4. Per cent of ever-married rural youth, by age group, gender and structural transformation typology

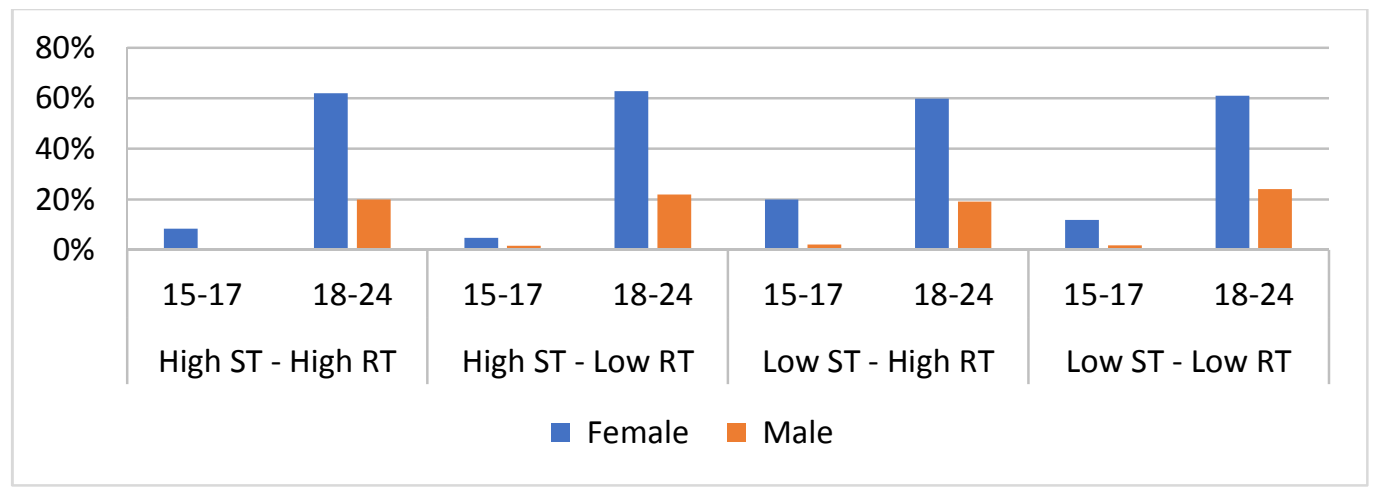

Note: ST: Structural Transformation; RT: Rural Transformation 


\subsection{Assets of rural youth}

\section{Human capital}

Although there is no systematic gender difference in secondary school attendance or in median years of schooling completed, where there are large differences, they favour male youth. Countries with high levels of structural and rural transformation are also those where male and female youth have similar levels of educational attainment; the proportions of females having attended secondary school and median years of schooling for young women may even be higher. High ST/low RT countries reveal a sizeable male disadvantage in schooling.

Years of schooling or levels of education attained are often used as a proxy for human capital. The patterns of education by gender vary across the four typologies. In high ST-high RT countries rural female and male youth have similar levels of educational attainment (figure 5). A slightly larger proportion of female youth have ever attended secondary school and female youth have, on average, completed a little more than nine years of formal education, compared with a little less than eight for male youth (figure 6). In rural areas of high ST-low RT countries, the female advantage disappears; male youth are more likely to have attended secondary school ( 82 per cent versus 77 per cent), though mean years of educational attainment are similar for male and female youth. The most dramatic gender differences in rural areas are observed in the low ST-high RT countries. Whereas 54 per cent of male youth have attended secondary school, only 35 per cent of female youth have, and male youth have attained nearly twice the number of years of education compared with female youth. In rural areas of low ST-low RT counties, educational attainment is low, though male youth have a slight advantage, having attained on average one additional year of education.

Figure 5. Per cent of rural youth (aged 15-24 years) who have ever attended secondary school, by gender and structural transformation typology

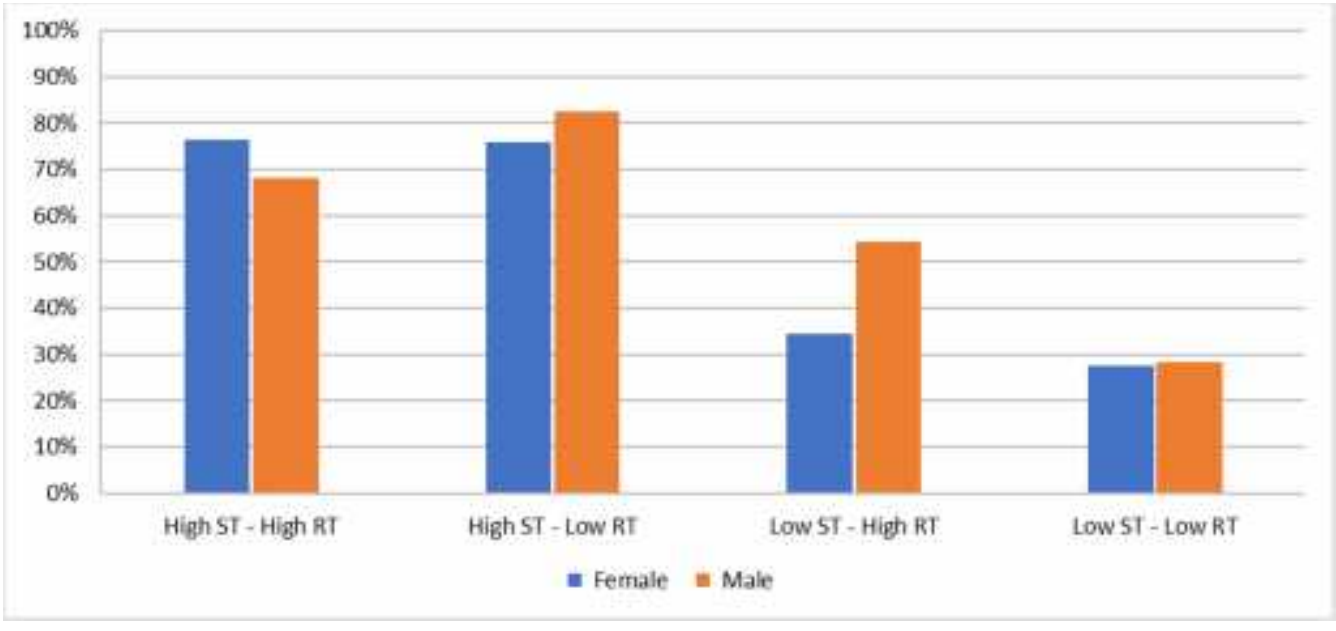

Note: ST: Structural Transformation; RT: Rural Transformation 
Figure 6. Median years of schooling for rural youth (aged 15-24 years), by gender and structural transformation typology

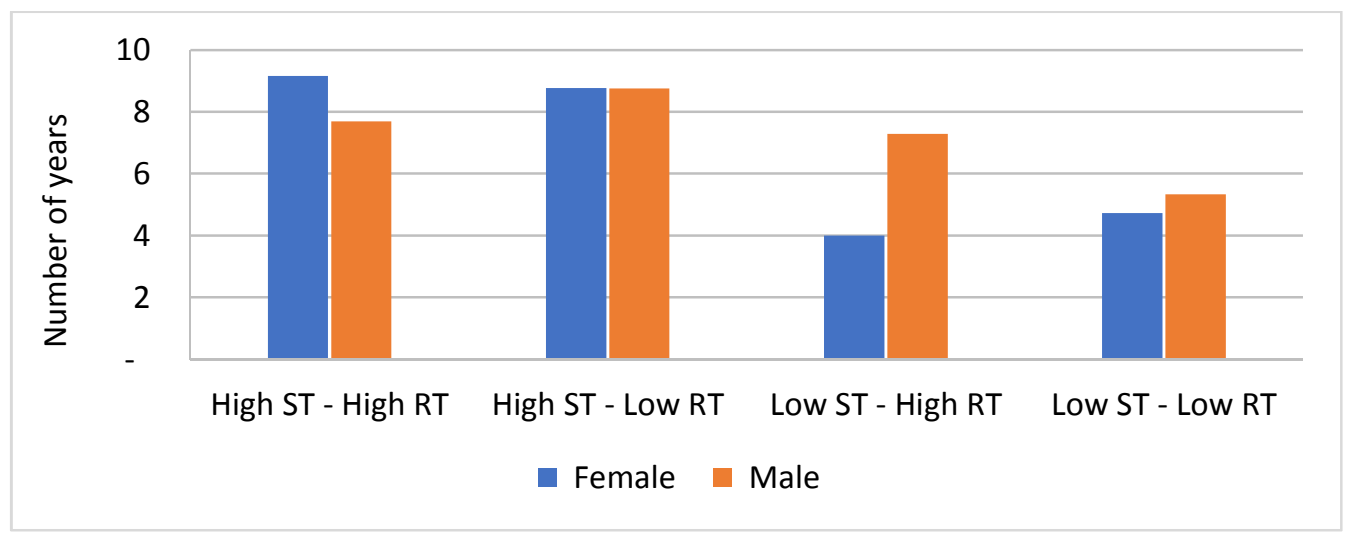

Note: ST: Structural Transformation; RT: Rural Transformation

\section{Land and housing}

A greater proportion of male youth own land solely or jointly in three out of the four ST-RT categories, and overall a greater proportion of male than female youth own land solely. A sizeable proportion of female youth do own land jointly; this is likely a consequence of marriage. There is an age-related increase in the proportion of male and female youth owning land, possibly related to marriage, increased responsibilities in the productive domain and the ability to legally own land.

The DHS surveys ask whether the respondent owns land and housing, and whether they own it individually or jointly with someone else. Overall land ownership (not disaggregated by sex) is higher in low RT countries. A larger proportion of male than female youth own land (whether solely or jointly) in three of the four typologies; low ST-low RT is the exception (figure 7). However, the large share of female youth owning land in low ST-low RT countries is mostly attributable to the joint ownership of land among female youth, which is likely a consequence of marriage. We also observe an age-related increase in the proportion of male and female youth owning land (from 15-17 to 18-24; see appendix 3 and appendix 4), possibly related to marriage, increased responsibilities in the productive domain and the ability to legally own land. In general, the gendered patterns of housing ownership are relatively similar to the patterns for land ownership.

Figure 7. Per cent of rural youth (aged 15-24 years) who own land, by gender and structural transformation typology

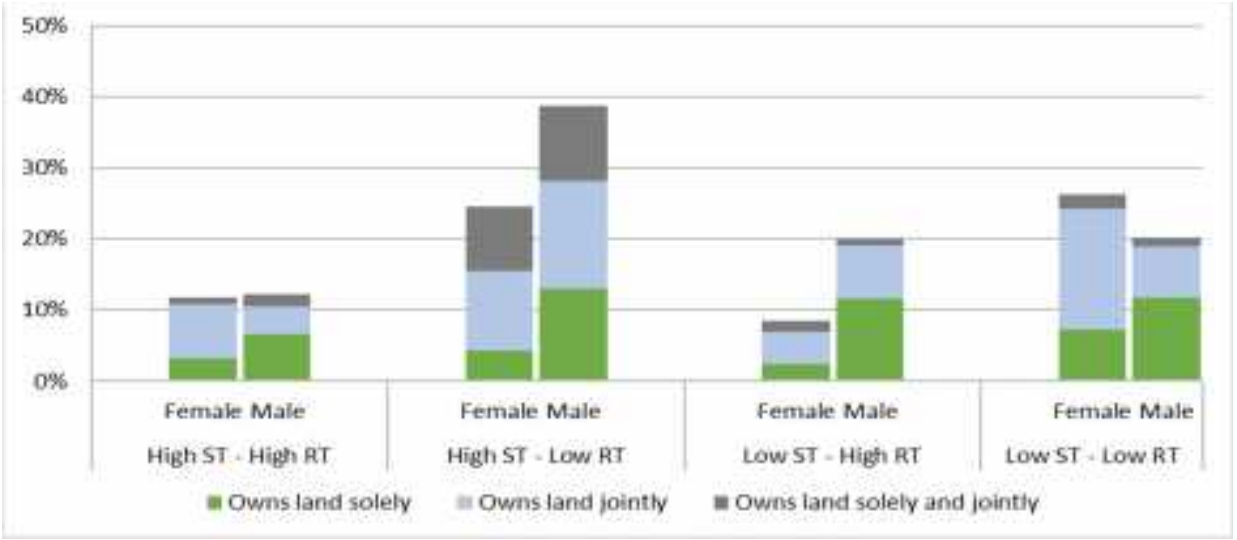

Note: ST: Structural Transformation; RT: Rural Transformation 


\section{Non-land assets}

Data from Ethiopia and Ghana show that both male and female youth accumulate non-land assets over time, with males owning more (number) assets than females. Proportionally, young men tend to accumulate agricultural and non-agricultural productive assets; young women's asset portfolios consist mostly of consumer durables.

In both Ethiopia (low ST-low RT) and Ghana (high ST-high RT), where we examined individual ownership of agricultural and non-agricultural assets, we find that male youth own larger numbers of both agricultural and non-agricultural assets (Table 2). Across all asset groups, the younger group (age 15-17) owns fewer items than the older group (age 18-24) for both male and female youth. Notably, male youth accumulate more of these assets, and the gender gap in asset ownership also grows between 15-17-year-olds and 18-24-year-olds.

For the younger group in both Ethiopia and Ghana, gendered ownership patterns for consumer durables and productive assets are similar. Male youth own more items by a small margin (2-3 items) (Table 2). Among 18-24-year-olds, however, this pattern is reversed, and female youth own more items than male youth, by a small margin ( 2 items) in Ghana and a larger margin ( 9 items) in Ethiopia. This pattern may be strongly tied to marriage, whereby female youth, who marry earlier, may acquire consumer durables upon and as a part of marriage.

\section{Political assets}

Possession of a National Identity Card: In rural Pakistan (low ST-high RT), we find that that the proportion of male youth (age 18-24) with a national identity card (67.4 per cent) exceed the proportion of female youth with such a card (45.3 per cent) (Table 3). Meanwhile, in rural Bolivia (high ST-low RT), a similar proportion of male (86.6 per cent) and female (87.1 per cent) youth (age 15-24) possess identity cards, and in rural parts of the Dominican Republic (high ST-high RT), the proportion of female (65.8 per cent) youth (age 16-24) with an identity card exceed the proportion of male youth with a card (61.1 per cent). We have data on too few countries to be able to generalize about gender biases in possessing an identity card, which could be required for political participation or to avail oneself of government services. This may reflect stronger women's legal rights and greater gender equity in education and formal labour force participation in Bolivia and the Dominican Republic, although it could also reflect stronger legal institutions and more equitable educational attainment and labour force participation in high ST economies. Women's legal rights and access to education and formal employment are weaker in Pakistan in general.

\section{Overall statement on assets}

Gender gaps in human capital (proxied by schooling) are relatively small or beginning to close, particularly in high ST/high RT economies. Where gender gaps in human capital exist (in low ST/high RT economies), they tend to be large and to favour men. Land and physical asset ownership tends to favour young men, although women also get access to land through joint ownership when they marry. We have limited information on political assets (proxied by possession of an identity card): they appear stronger in the high ST/high RT countries in Latin America compared with Pakistan. We hypothesize that this mirrors the general strength of legal institutions as well as differences in gender norms, which are more egalitarian in Latin America and the Caribbean than in Pakistan.

\subsection{Livelihoods and current activities}

Across ST/RT categories, a significantly larger proportion of male youth are currently employed. Roughly equal proportions of male and female youth are in school (with the exception of the low SThigh RT category, where more males are in school). Young rural women, however, are significantly 
more likely to be not in education, employment or training, with a large proportion already being married, with or without children.

The natural, human, physical, political and social assets of rural youth affect their livelihood strategies. Analysing the current activities of rural youth provides a glimpse into their livelihoods. Using selfreported current activities, we classify youth as either currently enrolled in school, currently employed, or not in education, employment or training (NEET). Because many youth, especially female youth, may be NEET because they are engaged in reproductive activities (maintaining a household and raising children), we further disaggregate NEET youth according to whether they are married and/or have children (self-reported in individual interview). Among currently employed female youth, we also consider whether they are employed on or off farms and whether they work for themselves, a family member or someone else.

We find that current school enrolment is higher among male youth compared with female youth in all four categories, when counting youth who are simultaneously working and in school (figure 8). The gender gap in current school enrolment is largest in the low ST-high RT countries (20 percentage points), possibly driven by Pakistan, and also large in low ST-low RT countries (16 percentage points).

The early withdrawal of female youth from the labour force, owing to early marriage, and their disadvantage in terms of schooling, is reflected in differences in employment status between rural male and female youth (figure 8). Across all four categories, a significantly larger proportion of female youth (compared with male youth) are not in the labour force, in education, or in training. Many of the NEET female youth, however, are married and/or have children. The high ST-low RT countries have the highest proportion of NEET female youth who are not married and have no children, which may be driven largely by India. Thus, childbearing, child-rearing and domestic responsibilities may preclude their ability to work or to continue schooling or training, although we note that the influence could go in the opposite direction - without schooling or employment opportunities, young women's best option may be to marry. Conversely, across the regions we examine, a larger proportion of male youth are currently employed.

Figure 8. Per cent of rural youth (aged 15-24 years) currently in school, employed or NEET, by gender and structural transformation typology

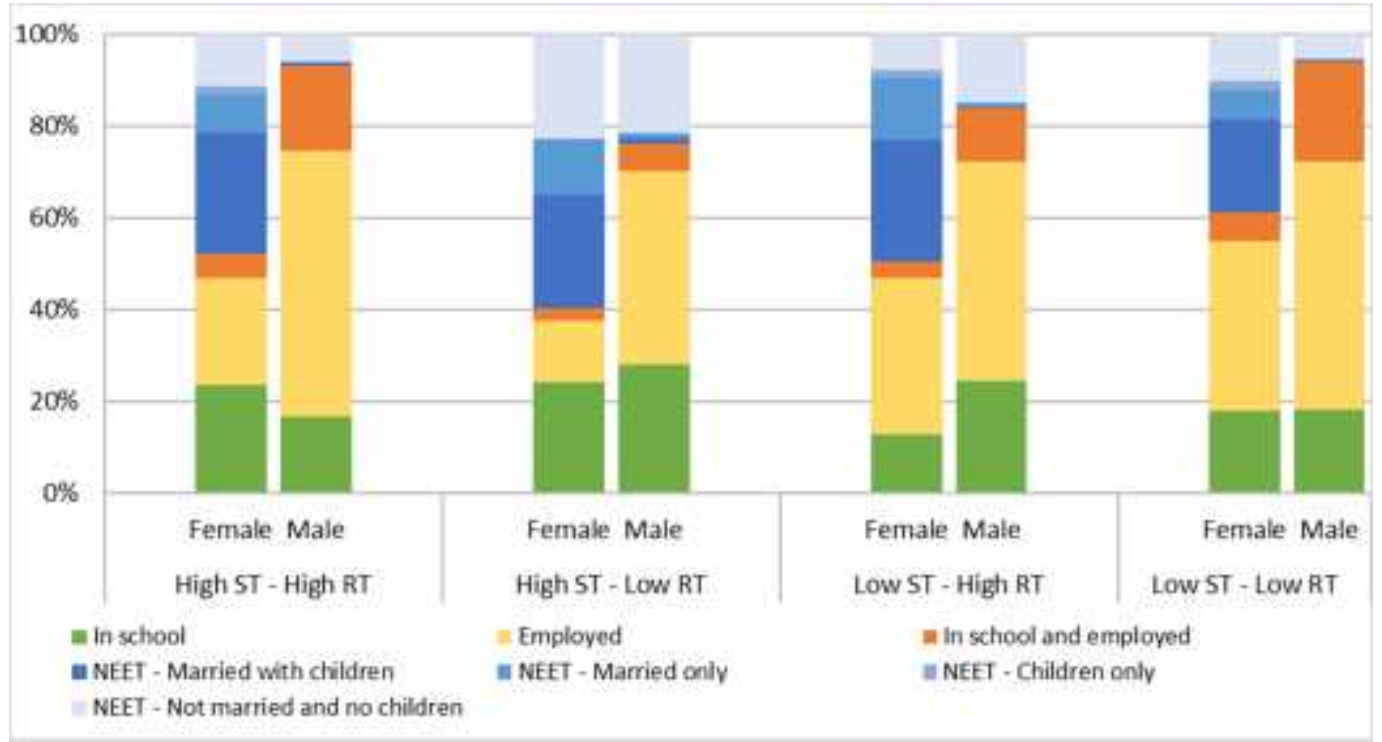

Note: ST: Structural Transformation; RT: Rural Transformation 


\section{Type of employment of rural female youth}

Most rural female youth who work on the farm work for family members in all but the low ST-high RT countries. Across ST-RT typologies, relatively few female youth work on a non-family member's farm. Off-farm work is more common in high ST-high RT and low ST-high RT countries compared with onfarm work. In low ST-high RT countries, entrepreneurial activities (off-farm employment for self) is particularly high (nearly half of all employment among rural female youth).

Data on the type of employer is only available for female youth. Among rural female youth who work on farms, in all but the low ST-high RT countries, most are working for a family member (figure 9); conversely, relatively few female youth work on a non-family member's farm across all four categories.

Figure 9. Per cent of rural female youth (aged 15-24 years) by work sector and type of employer, by structural transformation typology

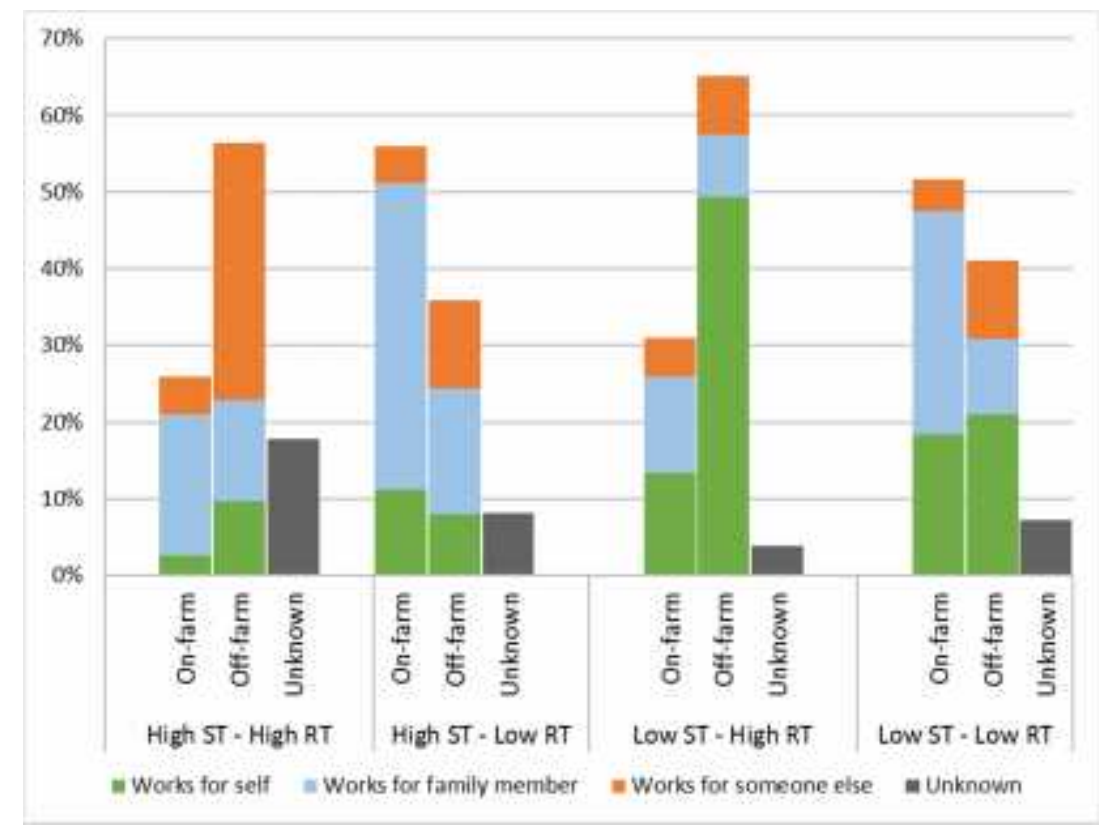

Note: ST: Structural Transformation; RT: Rural Transformation

In the low ST-high RT countries, slightly more rural female youth work on their own farms (compared with for a family member); this likely includes farms on land that is jointly owned with their husbands. Self-employment in on-farm work is less common, but accounts for a substantial share of employment activities in high ST-low RT and low ST-low RT countries.

Off-farm work is more common in high ST-high RT and low ST-high RT countries compared with onfarm work. In high ST-high RT countries, rural female youth who work off-farm are most often working for someone outside the family. In low ST-high RT countries, entrepreneurial activities (off-farm employment for self) rank particularly high (nearly half of all employment among rural female youth). Entrepreneurial activities also account for around 20 per cent of rural female youth employment in low ST-low RT countries.

\subsection{Youth transitions over time}

While gender gaps in the schooling attainment of young men and women are narrowing, with marked increases in the percentages of young women attending secondary school, and both young men and women are marrying at later ages, the employment patterns of those young people who remain in 
rural areas do not appear to have changed much. There are, however, visible differences across countries. A larger proportion of young men continue to be employed in the rural sector compared with young women in Bangladesh, where gender norms are more patriarchal. In Nepal, where gender norms remain patriarchal and male outmigration is extremely high, potentially altering rural social dynamics, the gender gap is smaller and continues to narrow. In rural Ghana and Bolivia, women participate heavily in agriculture and gender norms are less patriarchal than the two South Asian countries. Roughly similar proportions of male and female youth work in rural Ghana, and in Bolivia the gender gap is narrowing largely because of declining male youth employment, though trends in Bolivia in particular may be subject to the departure of significant numbers of both male and female youth from rural areas. Even if changes in gender norms may expand young women's potential opportunities and choices, schooling and labour force opportunities are necessary conditions for young women to participate equitably in rural and structural transformation. Thus this process cannot be taken in isolation from the labour market in general and the process of structural transformation.

While cross-country analysis provides a picture of young rural men and women at a given time, understanding how transitions to adulthood have changed over time requires longitudinal data. To describe how the characteristics and activities of rural youth have changed in recent decades, we use DHS data from four countries that have data covering up to a 20 -year time span. While we have representation across geographic regions, we cover only three of the four ST-RT groups. None of the low ST-high RT countries had sufficient longitudinal data to undertake this analysis.

The countries we include are: Ghana (1993, 1998, 2003, 2008 and 2014) (high ST-high RT), Bangladesh (1993/94, 1996/97, 1999/2000, 2004, 2011, 2014) (high ST-low RT), Bolivia (1994, 1998, 2003 and 2008) (high ST-low RT) and Nepal (2001, 2006, 2011 and 2016) (low ST-low RT). The Bangladesh and Nepal (2001) samples were limited to ever-married women and men.

Ghana is a high ST/high RT economy. With such dramatic transformations of the economy one expects that the transition to adulthood would have changed for youth over time. Indeed, in Ghana (grey lines) we observe a huge decline in the proportion of female youth who have ever married: this decreased by about 30 percentage points between 1992 and 2013 (figure 10, appendix 5). When the transition to marriage is considered in terms of relative differences between male and female youth, in Ghana the proportions of male and female youth who have ever married are both decreasing and converging. Ever-married rates for both female and male youth have decreased over time, with the gap in ever-married youth decreasing from 44 percentage points in 1993/94 to 23 percentage points in 2014. In 2008, Ghana (grey lines, figure 11) closed the gender gap in median years of schooling, but the convergence was due to decreasing number of years of schooling for male youth, and an increasing number of years of schooling for female youth.

Employment patterns reflect gender norms, which often dictate that men should be earning incomes, but because these data do not include urban youth (and rural-to-urban migrants), they may not reflect how migration has affected employment patterns (figure 12). Additionally, the increase in average educational attainment across these countries may mean that youth are entering the labour force later than earlier generations. In Ghana, similar percentages of young men and women are employed, and this does not seem to have changed dramatically over time. This may reflect the consistently high involvement of Ghanaian women in agriculture. 
Gender, rural youth and structural transformation: Evidence to inform innovative youth programming

Figure 10. Trends in marriage/union among rural youth aged 15-24 years, by gender

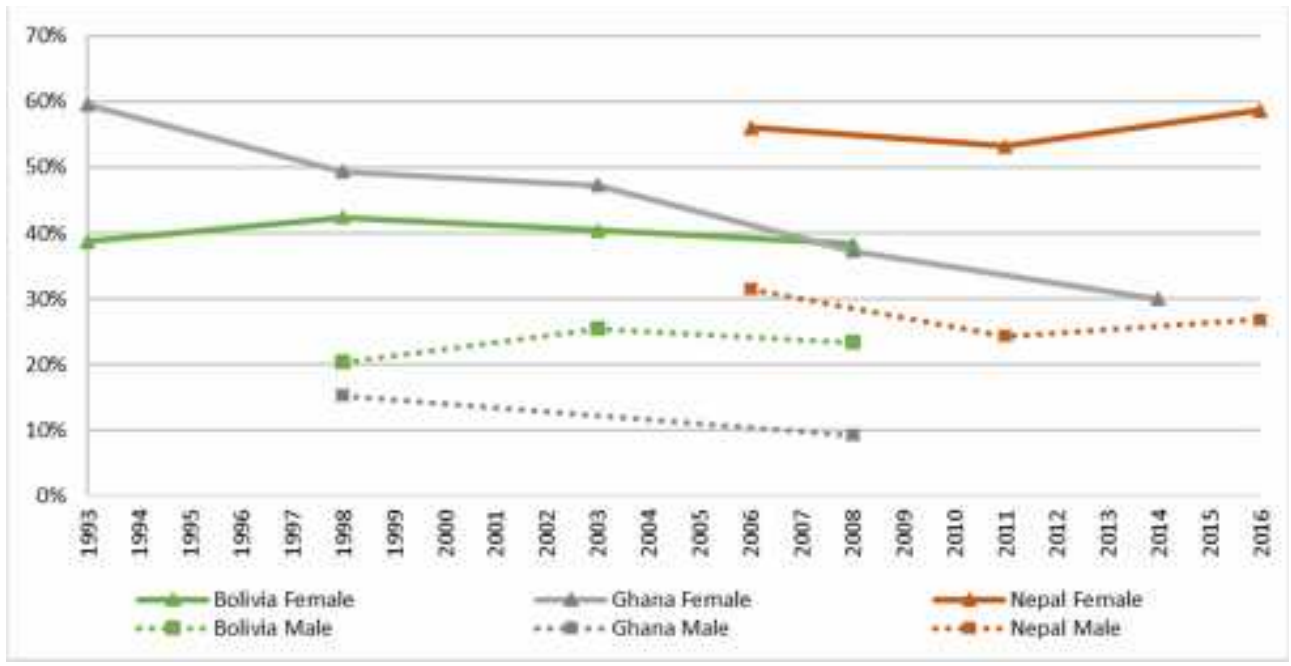

Figure 11. Trends in median years of schooling among rural youth aged 15-24 years

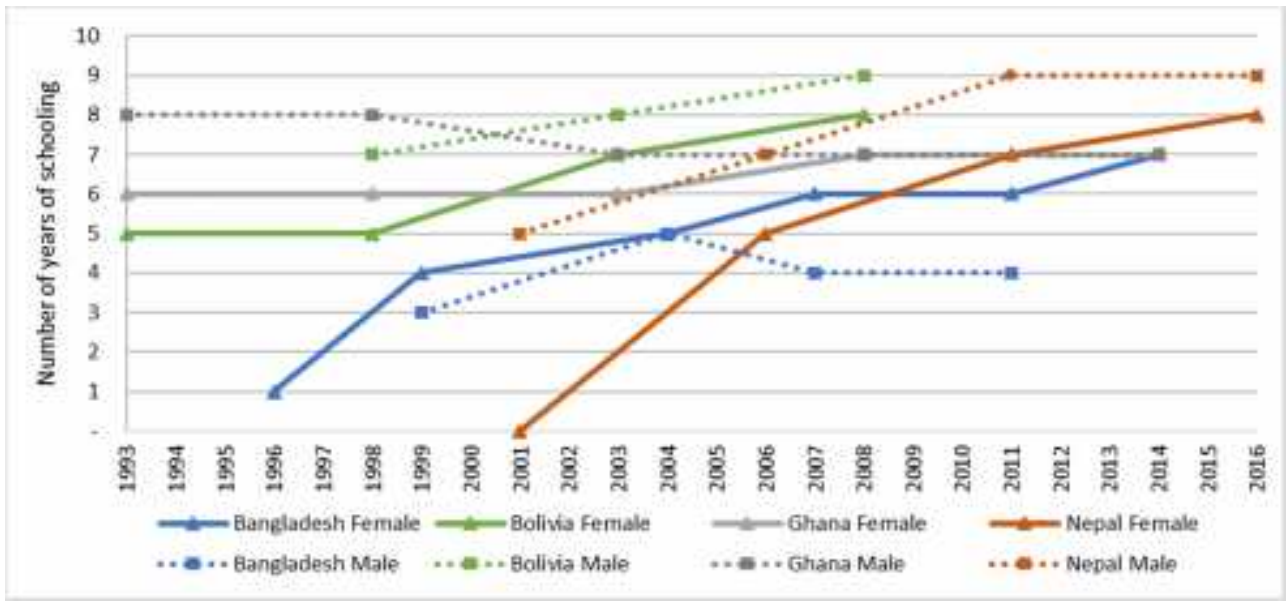

Figure 12. Trends in employment among rural youth aged 15-24 years

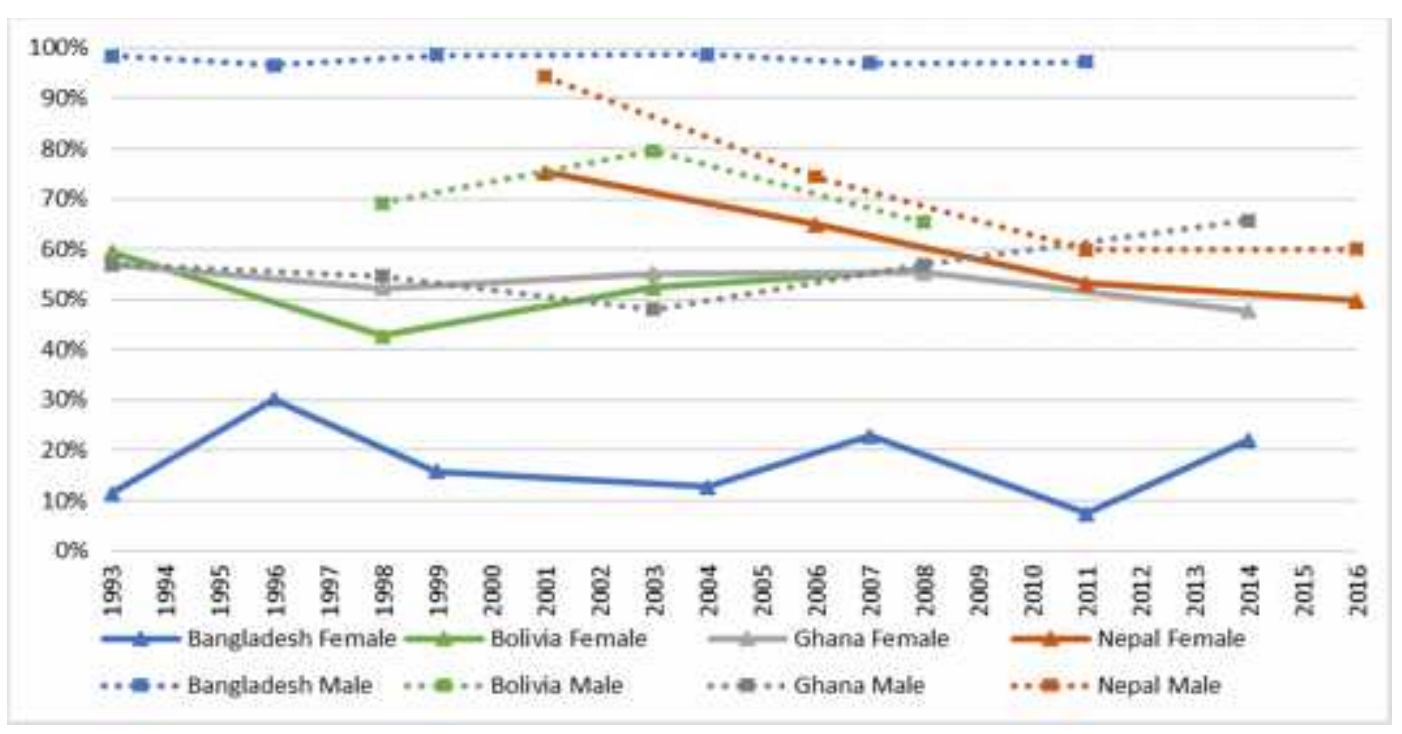


Bangladesh and Bolivia, two high ST/low RT economies, offer interesting comparisons. Both married female and male youth in rural Bangladesh are achieving higher levels of educational attainment. This increase (from 0 to 7 ) is particularly dramatic for female youth and suggests that they are entering both marriage and adulthood with a greater accumulation of human capital. In rural Bangladesh (blue lines), where the sample is limited to ever-married youth, married female youth have completed more years of schooling than married male youth. Though these groups may not be directly comparable (as men typically marry later), the trends over time are noteworthy. In Bangladesh, where rural women's mobility is limited, women have lower levels of human and physical capital than men, young married women are often tied to domestic work, and young rural women's employment rates are much lower than married male youth. These numbers, however, would look quite different if they accounted for the large numbers of young unmarried women who migrate to urban areas to work in garment factories.

In Bolivia (green lines, figure 10Error! Reference source not found.) the percentage of ever-married female youth is relatively constant across the time period covered, but a closer look at 15-17-year-olds (Appendix ) reveals a small decline in the proportion of female youth who married early (from 10 to 9 per cent). When the transition to marriage is considered in terms of relative difference between male and female youth, in rural Bolivia the proportions of male and female youth who have ever married are converging, and the gap between female and male marriage rates decreased by seven percentage points between 1998 and 2008. In Bolivia (green lines, figure 11), male youth have consistently had higher number of years of schooling, and the gender gap in schooling has not changed over time. Among female youth in Bolivia, the share of those working is increasing, while that of men is declining.

In Nepal (orange lines, figure 10) the percentage of ever-married female youth is relatively constant across the time period covered, despite a small decline in the proportion of female youth who married early (from 22 to 20 per cent). While in rural Bolivia and Ghana the proportions of male and female youth who have ever married are converging, in Nepal (orange lines, figure 10), this gender gap increased by seven percentage points between 2006 and 2016. These trends are largely driven by the 18-24-year age group (appendix 7). Nepal had the lowest female educational attainment among all four countries in 2001. However, the gender gap in schooling in Nepal is closing (figure 11), mainly because of the steep increase in female educational attainment. The rising educational attainment of both young men and young women has not led to increased employment in rural areas, however. In Nepal, the declining percentage of rural youth who are employed, and the small gender gap in employment, may partly reflect the rising outmigration of young men and the possible withdrawal from the rural labour force of those left behind. How extensive male outmigration changes gender dynamics in rural areas is worth investigating.

\subsection{A summary of gender issues by ST-RT category}

\section{High ST-high RT countries ${ }^{2}$}

High ST-high RT countries tend to have relatively high levels of gender equality and include a large number of Latin American countries and two South-East Asian countries with egalitarian gender norms. There are high rates of education for both boys and girls, and the gender gap in schooling favours girls. In this category, we observe the highest levels of off-farm employment for young women who are working. A higher proportion of young women in rural areas are ever married, compared with young men, but this holds across all ST-RT categories. Despite high educational attainment, many female youth are still left out of the labour market, and a substantial share of NEET female youth are married without children. This suggests that the full potential of their human capital is not being realized.

\footnotetext{
${ }^{2}$ High ST-high RT: Colombia 2015, Dominican Republic 2013, Egypt 2014, Ghana 2014, Guatemala 2014/15, Honduras 2011/12, Indonesia 2012, Kyrgyz Republic 2012, Namibia 2103, Peru 2012, Philippines 2013.
} 


\section{High ST-low RT countries ${ }^{3}$}

Young men and women in high ST-low RT countries have relatively high median levels of education (greater than eight years of schooling) with little or no gender gap. (To the extent that there is one, it favours boys). Among all four categories, this category has the highest proportion owning land, but a large gender gap in landownership favours young men. Young women in rural areas also have the highest levels of those not in education, employment or training across country typologies; this trend is somewhat driven by Bangladesh, but 50 per cent of young rural women in Gambia, Lesotho and Senegal are also NEET. One can hypothesize that the low levels of rural transformation have not created opportunities for young rural women that could provide incentives for them to continue schooling, undergo training or engage in gainful employment.

\section{Low ST-high RT countries ${ }^{4}$}

Both male and female rural youth have relatively low levels of schooling in low ST-high RT countries, but the gender gap in schooling favours males. Although the proportion of young women who are ever married is not significantly different from the other categories, their experiences are distinct in two ways. First, they marry early (between 18 and 35 per cent of 15-17-year-old girls in the African countries in this category are married), which suggests that they may miss out on opportunities for human capital accumulation. Second, these women are more likely to be living with their in-laws, rather than with their parents or in nuclear households with their husbands. Young women in the low ST-high RT category have the lowest median years of schooling; the gender gap in schooling attainment is greatest. Low levels of human capital relative to young men and co-residence with inlaws may have negative implications for young rural women's relative empowerment within their households as well as their ability to make decisions about their livelihoods. Interestingly, among young women who are working, the highest proportion are working off-farm for someone else, rather than on-farm. In the context of high RT, the returns to work on-farm may be higher than off-farm. The labour force participation is primarily driven by the African countries in this group, and off-farm employment for a non-family member is likely to be in the service sector.

\section{Low ST-low RT countries ${ }^{5}$}

This category is primarily comprised of countries from sub-Saharan Africa. Both young men and young women in the low ST-low RT countries have much lower levels of education - the lowest among all country categories - with a slight gender gap favouring boys. Young women in this country category have higher rates of land ownership than young women in the other categories, and in this age group the gender gap in landownership favours women when both sole and joint landownership are considered (a larger proportion of young men own land solely). A much larger proportion of young men are in school and employed, and among young women who are employed, a large proportion work on-farm for a family member. Rates of self-employment for young women are similar for off-farm and on-farm work.

\footnotetext{
${ }^{3}$ High ST-low RT: Bangladesh 2014, Cameroon 2011, Gambia 2013, India 2015/16, Lesotho 2014, Senegal 2016, Zambia 2013/14.

LLw ST-high RT: Cote d'Ivoire 2011/12, Chad 2014/15, Nigeria 2013, Pakistan 2012/13, Tajikistan 2012.

${ }^{5}$ Low ST-low RT: Afghanistan 2015, Benin 2011/12, Burkina Faso 2010, Burundi 2010, Cambodia 2014, Ethiopia 2016, Guinea 2012, Kenya 2014, Malawi 2015/16, Mali 2012/13, Mozambique 2011, Myanmar 2015/16, Nepal 2016, Niger 2012, Rwanda 2014/15, Sierra Leone 2013, Tanzania 2015/16, Togo 2013/14, Uganda 2016.
} 


\section{Gender-sensitive programming for rural youth: lessons learned from impact evaluations of youth-oriented interventions}

Comprehensive reviews of impact evaluations of youth employment programmes (Fox and Kaul, 2018) and programmes addressing the economic empowerment of adolescent girls (Baird and Özler, 2016) have recently been completed. Thus, we do not undertake a new review for this paper. Instead, we draw on these reviews, focusing on the studies that have made a deliberate attempt to measure gender-differentiated impacts. The Fox and Kaul review includes programmes in vocational and skills training, self-employment and a few programmes targeting adolescent girls; the Baird and Özler review focuses exclusively on adolescent girls. For this paper, we draw on all the studies in the Fox and Kaul systematic review of impact evaluations of youth employment interventions for which the abstracts reported differential analysis by gender, regardless of whether results differed significantly for male and female youth. We also included studies that focused on young women (typically adolescent girls) that were included in both literatures (i.e. the Fox and Kaul and Baird and Özler reviews).

Because of the focus on economic outcomes in the IFAD report, we do not review the interventions in the Baird and Özler review that are primarily on reproductive health but note that reproductive health is an important consideration for young women and men alike. Our emphasis is not on the impacts of the interventions per se, but on factors that may have led to differential impacts for young men and women, and that should be considered when taking gender into account to design interventions for rural youth.

The interventions addressing challenges facing youth fall into two broad categories. The first focuses on youth employment and livelihoods programming and typically on narrow economic outcomes (with some exceptions), primarily in urban or peri-urban areas. Many of these programmes target young men, or may be directed at women, though not necessarily young women. The second focuses on investment in adolescent girls, with an emphasis on delaying marriage and childbearing and avoiding risky sexual behaviour, with economic outcomes being considered among a range of other outcomes that may include well-being, empowerment and reproductive health. There is some overlap between these two areas of programming, but it is small.

\subsection{Vocational and skills training}

Most of the studies on vocational and skills training reviewed by Fox and Kaul (2018) are based on impact evaluations in urban or peri-urban areas and are not consistent in terms of the direction of their gendered impacts. Because they are urban studies, the findings may not be completely relevant to rural youth. Nevertheless, some findings may highlight the feasibility or appropriateness of some types of programmes in rural areas. For example, the finding that a training programme for unemployed urban youth in Colombia improved women's productivity, but increased men's earnings by increasing the formality of employment (Attanasio et al., 2015) may indicate that this type of programme may not be applicable in rural areas, where the possibility of formal employment is limited. Nevertheless, some aspects of vocational training programmes may be transferable to rural areas. Acevedo et al. (2017), for example, study the interaction between job and soft-skills training on expectations and labour market outcomes in a youth training programme in the Dominican Republic. A year after completing the programme, both male and female participants reported increased expectations for improved employment and livelihoods, but the positive results were sustained for women and reversed for men after 36 months. Interestingly, the authors conclude that the soft-skills training and internship, and not vocational training, led women to achieve higher employment in jobs with higher salaries that are more satisfying. In the longer run, the training was transformative for women, who were more optimistic and had higher self-esteem and lower fertility, whereas it tended to discourage men, whose expectations 
increased but who did not get higher-wage offers. The positive impact of soft-skills training for young women, but not the vocational training component, raises the possibility that soft skills may be valuable because they are "portable" whereas hard skills may be specific to a particular industry or sector (e.g. refrigeration, transport) and may be difficult to transfer if industries do not have sufficient demand for workers. If these skills are portable, soft-skills training may be valuable for young women, even in rural areas.

The success of vocational training programmes for young women, whether in rural or urban areas, however, depends on whether men and women trainees start with equal endowments and whether women face barriers to labour market participation. For example, an evaluation (Alzua, Cruces and Lopez, 2016) of the short-, medium- and long-term impacts of a life-skills and vocational training programme for low-income youth in Argentina, which included internships with private sector employers, found that the programme benefits accrued mostly to men. This was because the participating men tended to be younger and had a lower probability of having children and cohabiting. Young men also had higher average educational achievements and substantially higher levels of preintervention formal employment than did the young women. The programme might, therefore, have been more effective for younger, more educated beneficiaries and more experienced participants, which may explain the difference in results between male and female participants.

Even if female youth benefit from programmes, their design may favour those with more initial wealth or schooling. For example, while a job skills programme in Liberia (Adoho et al., 2014) had consistently positive impacts on employment and earnings across communities, educational backgrounds and wealth levels, the highest impacts were obtained for those in the middle of the wealth distribution, and for girls with higher educational levels. This is consistent with the programme's selection criteria, which included basic literacy so that participants would be able to make use of a classroom-based skills course.

Other gender-specific constraints may limit women's participation and completion in training programmes. Maitra and Mani (2017) found that, while a subsidized vocational training programme targeting women aged 18-39 residing in low-income households in India increased their employment, hours worked and incomes, both in wage work and self-employment, many women were unable to complete the programme. Although the programme was highly cost-effective, credit constraints, distance and lack of proper childcare support were important barriers to programme completion. These barriers could prevent women from participating and completing training programmes of any kind, not just vocational training.

An evaluation of a training programme in Malawi (Cho et al., 2013) provides insights into how training programmes may not necessarily benefit young women. Because self-employment is more widespread than formal employment, the programme offered apprenticeships instead of classroombased training. The master craftsperson (MC) workshops were located in urban areas, while many of the trainees lived in rural areas. Men had generally better training outcomes than women. While improvements in self-reported skills were similar across genders, male trainees exhibited greater improvement in subjective measures of well-being and confidence compared with women, but women's savings and earnings-related activities decreased. There are several reasons why women may not have benefited as much as men from this training. First, women are more likely to drop out due to adverse shocks (severe illness or injury), and to participate only when alternative opportunities disappear (e.g. being fired from a previous job). Young women are also more constrained: girls are on average less educated than boys at baseline, have more dependents and spend more time on domestic chores as opposed to paid labour or business activities. Women (but not men) self-report "family obligations" and "getting married" as the main reasons they drop out. Second, participating in training is expensive and trainees - especially girls - have to draw down their savings to do so. This is partly due to differences in the training experience: men are more likely to have received financial 
support from MCs during the training. Distance to the training facility is a greater constraint for girls; boys attend more regularly and are three times as likely to receive a paid job offer from the MC following the training period. Overall, women are significantly more constrained in their decisionmaking, leading to a worse training experience, less support and ultimately worse training outcomes.

In contrast, BRAC's Empowerment and Livelihoods for Adolescents (ELA) programme in Uganda, which was implemented in a mix of urban and rural communities, appears to have been successful (Bandiera et al., 2017). In this two-pronged intervention, adolescent girls are simultaneously provided (1) vocational skills to enable them to start small-scale income-generating activities; and (2) life skills to build knowledge, enabling girls to make informed choices about sex, reproduction and marriage. In contrast to most skills programmes, the intervention is delivered from designated "adolescent development clubs" rather than in schools, and can thus reach school drop-outs as well as girls currently enrolled in school. Relative to adolescents in control communities, after two years the intervention raises the likelihood that girls engage in income-generating activities by 72 per cent (mainly driven by increased participation in self-employment) and raises their monthly consumption expenditures by 41 per cent. Teen pregnancy falls by 26 per cent, early entry into marriage/cohabitation falls by 58 per cent, the share of girls reporting sex against their will drops from 14 per cent to almost half that level, and preferred ages of marriage and childbearing increased. It is interesting to note that the "girls' clubs" modality was developed by BRAC in Bangladesh, where it reached one million adolescent girls between 1993 and 2013.

What made this intervention different from others? Bandiera et al. (2017) identify the following elements: (1) it targets adolescent girls, the majority of whom do not already engage in selfemployment activities at baseline; (2) it has an intense training period lasting far longer than a few weeks; (3) the training covers general business skills as well as technical knowledge and sectorspecific content; and (4) it bundles together vocational skills with life skills that aim to simultaneously raise girls' social empowerment. This suggests that programmes addressing both the productive and reproductive spheres of adolescent girls' lives may have greater impacts than those "single-pronged" programmes that have focused on economic or reproductive health constraints in isolation.

\subsection{Credit and cash grants for entrepreneurs}

Given the size of the informal sector in rural areas, could programmes that provide credit and cash grants to young rural entrepreneurs be effective? Again, while most studies on this topic reviewed in Fox and Kaul (2018) were conducted in urban areas, and many of them with adult women, they may offer some insights into interventions for rural entrepreneurs. We aim to extrapolate these findings such that they are applicable to rural female youth, particularly those who are old enough to access financial services.

Microfinance programmes have been proposed to reduce credit constraints that may hamper the ability of women to take advantage of their entrepreneurial skills. However, recent studies, such as Banerjee et al. (2015), cast doubt on the microfinance model. But neither are cash grants necessarily the solution. In an experiment randomly providing cash grants to microenterprises in Sri Lanka, which was not specifically targeted to youth, de Mel et al. $(2014)$ found that the capital injections generated large profit increases for male microenterprise owners, but not for female owners.

Could business training combined with loans or cash grants be a solution? An experiment in urban Sri Lanka (Ibid.) provided business training by itself, and in combination with a grant, to self-employed women. Again, this programme was not specifically directed at young women. For women already in business, training led to some changes in business practices but not in business profits, sales or capital stock. In contrast the combination of training and a grant led to large and significant improvements in business profitability in the first eight months, but this impact dissipated in the second 
year. For women interested in starting enterprises, receiving a grant resulted in poorer women opening businesses, but did not increase net business ownership. However, training appears to have increased the profitability and business practices of the businesses started, suggesting it may be more effective for new owners than for enhancing existing businesses. The authors highlight the challenge in getting subsistence-level female-owned microenterprises to grow, and suggest that providing capital and skills may not address the binding constraints that these entrepreneurs face in growing their businesses. Although the authors suggest that targeting young women who are starting their businesses may be more effective, this needs to be tested in other settings.

Findings from two labour market interventions targeting young women in Nairobi are similar (Brudevold-Newman et al., 2017). One treatment offered participants a "microfranchising" programme that combined vocational and life skills training with start-up capital and ongoing business mentoring; a second treatment provided women with an unrestricted cash grant, but no training or other support. Both interventions had economically large and statistically significant impacts on income over the medium term ( 7 to 10 months after the end of the interventions), but these impacts dissipated in the second year after treatment in both treatment arms. It appears that individuals in the sample were savings-constrained, and launched unsustainable businesses to stretch out the capital infusions provided by the interventions. The training component of the franchise intervention also did not increase individual productivity sufficiently to create sustainable businesses. It also appeared that credit constraints were not the main obstacle preventing the poor - particularly poor women - from launching and expanding profitable, sustainable businesses.

A third study (Fiala, 2013) randomized the provision of loans, cash grants, business skills training, or a combination thereof to microenterprise owners in Uganda, without any age-related targeting. This programme ended up benefiting men: those with access to loans and training reported significantly higher profits. The loan-only intervention clearly alleviated credit constraints for men, as the loans led to large increases in business profits, but the impacts did not last. There were no impacts from the grant intervention, and no effects for women from any of the interventions. Why were there no impacts for women? The author points to family pressures, which are more constraining for women. Keeping cash in hand was difficult when there is pressure to spend money on school fees, health care and funerals; these pressures were particularly acute for women whose family members lived nearby. In contrast, men often do not face the same pressures and instead benefit from having family nearby to use as labour. Keeping cash in hand may be even harder for female youth, compared with adult women, as they may feel pressure from older family members.

Finally, the only programme that was successful in improving economic outcomes for women had much weaker impacts on social and empowerment outcomes. Blattman et al. (2014) study an NGOimplemented programme that gave cash grants of approximately US $\$ 150$ and basic business skills training to the very poorest and most excluded women aged 14-30 in the war-affected region of northern Uganda. The women were encouraged by the NGO to begin retail trading, while continuing their farming and other miscellaneous activities. A year after the intervention, monthly cash earnings doubled, cash savings tripled, and short-term expenditures and durable assets increased 30 to 50 per cent relative to the control group. The treatment also had the biggest impact on people with the lowest initial levels of capital and access to credit. However, although the programme leads to relatively large increases in income and wealth, there is no effect on women's independence, status in the community or freedom from intimate partner violence (though the programme does not increase a woman's probability of experiencing partner violence).${ }^{6}$ There is also little evidence that paying attention to

\footnotetext{
${ }^{6}$ These results were obtained from a Randomized Controlled Trials comparing baseline and endline questions on these topics, which were then aggregated into indices of economic decision-making, attitudes towards gender norms, supportive behaviour, independence and domestic violence. Even if answers to these questions were selfreported, the experimental design, the use of baseline and endline data to compute impact estimates, and the fact
} 
men's roles in the household leads to better empowerment or economic success, although there is promising improvement in partner support and relationships, and there is little effect on psychological or social well-being from this reduction in poverty. The limited impacts on empowerment-related outcomes may arise from the reality that gender norms are slow to change.

The experiences from the impact evaluations described above point to the limited potential for increasing wage employment and mixed results for making self-employment more profitable, particularly for young women who may start out with lower levels of human and physical capital than men of the same age, and who may face particular gender-based constraints. Family pressures are an important constraint for women - proximity of the family was a blessing for men, who could tap additional labour, but not necessarily for women. Women also needed to balance their domestic responsibilities and relationships within the family with the needs of their businesses. Maitra and Mani (2017) also point out that cash injections directed at women could be confiscated by their husbands and other members of their household, leading to considerable inefficiencies, especially for female youth, who are likely to have lower status within their households. The most successful programme that we reviewed, ELA in Uganda (Bandiera et al., 2017), may have succeeded because it deliberately addressed both the productive and reproductive spheres of young women's lives, compared with "single-pronged" programmes that focused on economic or reproductive health constraints in isolation.

\subsection{Programmes potentially affecting adolescents and their families}

The above programmes focus on young men and women as wage earners and entrepreneurs, but not on the younger group of youth, who may be living with parents and older relatives (including in-laws), and who may not have the agency to make decisions regarding future investments in human capital and/or seeking employment. Most of the programming in this area has focused on adolescent girls (see the review by Baird and Özler, 2016, also see Quisumbing and Pinkstaff, 2016).

Two types of programmes deserve mention: (1) programmes that encourage parents to continue investing in girls' human capital (schooling) such as conditional cash transfers; and (2) programmes that aim to delay marriage by providing incentives. Although these are different types of programmes, they may be combined.

Conditional Cash Transfers (CCTs) in Latin America and elsewhere have increased schooling participation rates, had larger impacts on children in poorer households and during years of transition into school or between school levels, and had larger impacts on girls than boys (see review in de Brauw et al., 2015). However, even in a "typical" CCT, impacts can be quite different across groups. An evaluation of the Bolsa Familia (BF) programme in Brazil, for example, found that impacts vary by sex, age and location (Ibid.). On aggregate, BF increased girls' school participation by 8.2 percentage points, and had no significant impact on boys. Further disaggregation by location showed that impacts on participation and grade progression were driven by girls in rural areas. The authors conclude that $\mathrm{BF}$ is widening a gap that already favours girls, suggesting that, in this context, it is important to understand better why such programmes are more successful at promoting older girls' education than boys' education.

Programmes that use cash and assets transfers to delay marriage include Apni Beti Apna Dhan (ABAD) in India, Kishoree Kontha in Bangladesh, the Zomba Cash Transfer Program in Malawi, and the Berhane Hewan programme in Ethiopia (see review in Baird and Özler, 2016). Although the specific modalities differ, these programmes provide incentives (savings accounts, cooking oil, cash

that indicators were based on an index rather than responses to individual questions about whether status improved make it unlikely that the self-reported nature of the data introduced bias into the responses. 
transfers, a goat) to girls and their families, with varying degrees of success in changing gender norms regarding early marriage.

A third type of programme could be information and mass media programmes that emphasize the growth of employment opportunities for women. Jensen (2012), for example, reports on the impacts of providing three years of recruiting services to help young women in randomly selected rural Indian villages get jobs in the business process outsourcing (BPO) industry. Young women in treatment villages were significantly less likely to get married or have children during this period, choosing instead to enter the labour market or obtain more schooling or post-school training. Women also report wanting to have fewer children and to work more steadily throughout their lifetime, consistent with increased aspirations for a career. These results suggest that the process of structural transformation could improve schooling and employment outcomes even without deliberate policy interventions, citing the rise of the BPO sector, along with rapid growth in the white-collar service sector more generally, which is shifting the Indian economy away from agriculture and manufacturing. This shift is likely to continue to generate a greater demand for educated female labour and a corresponding increase in female labour force participation. Structural transformation will eventually change opportunities for women - the question is the speed at which the change occurs in societies with well-entrenched gender discrimination.

\section{Conclusions}

In conclusion, we find that marriage, childbearing and gender norms surrounding the transition to adulthood both shape the opportunities and constraints for youth and make them very different for young men and young women. At the same time, where a particular country lies in terms of the ST/RT typology, as well as its underlying gender norms, may influence the types of opportunities available to young men and women. For example, countries with high levels of structural and rural transformation and with relatively egalitarian gender norms may be associated with better opportunities for young women. These are countries where the growth of non-agricultural GDP may create higher returns to schooling, which in turn encourages parents to invest in their children's education. If these countries also have more egalitarian gender norms, parents would invest in both girls' and boys' schooling, and the growth of the non-agricultural sector could create employment opportunities for young men and women alike. Regardless of where countries fall in the ST-RT typology, investments in human capital (including reproductive health) are important for young women and young men.

Programmes and interventions seldom discuss or address the structures of constraint that differ for young men and young women, although these are sometimes acknowledged as reasons for the lack of success. Using a gender lens reminds us that we must consider five key dimensions. First, social norms define what is work and what is appropriate work for youth. These shape the opportunities that youth have and the choices that they make - and these differ for young men and young women. Second, care work and reproductive work also shape the choices of youth, and again these differ markedly for young men and young women. This feeds into the third issue, concerning the differential time constraints for young men and young women. These constraints are both in terms of the amount of time that they have for work and the structure of these time constraints. It is not just the number of hours that they have available, but which hours are available and whether they control their use of time. Fourth, youth face structural barriers in labour markets, and the returns to labour will differ for young men and young women. Finally, young men and young women differ in their access to a wide range of assets and resources, including both those useful for self-employment and those needed to find and keep wage employment. 
Gender, rural youth and structural transformation:

Evidence to inform innovative youth programming

The limited evidence on the gendered impacts of interventions may stem from gaps in programming for young men and young women, possibly arising from the failure to consider gender differences in transitions to adulthood, and thus the failure to intentionally design interventions that take them into account. The limited evidence may also arise from the tendency of reviews of impact evaluations to focus on evaluations based on Randomized Controlled Trials as well as the possibility that interventions are not even evaluated. Because of this, we may be missing important findings on programmes on rural male and female youth for which impact evaluations have not been conducted. Other evaluations, including those based on qualitative analysis, may provide insights into how such programmes differently impact young men and young women. These types of analysis would also provide insights into how gender roles provide different constraints and opportunities for male and female youth in rural areas. 
Table 1. Weighted means of select indicators for rural youth aged 15-24 years, by gender and structural transformation typology

\begin{tabular}{|c|c|c|c|c|c|c|c|c|}
\hline & \multicolumn{4}{|l|}{ Female } & \multicolumn{4}{|l|}{ Male } \\
\hline & High-High & High-Low & Low-High & Low-Low & High-High & High-Low & Low-High & Low-Low \\
\hline & $\begin{array}{l}\text { Mean } \\
\text { (SE) }\end{array}$ & $\begin{array}{l}\text { Mean } \\
\text { (SE) }\end{array}$ & $\begin{array}{l}\text { Mean } \\
\text { (SE) }\end{array}$ & $\begin{array}{l}\text { Mean } \\
\text { (SE) }\end{array}$ & $\begin{array}{l}\text { Mean } \\
\text { (SE) }\end{array}$ & $\begin{array}{l}\text { Mean } \\
\text { (SE) }\end{array}$ & $\begin{array}{l}\text { Mean } \\
\text { (SE) }\end{array}$ & $\begin{array}{l}\text { Mean } \\
\text { (SE) }\end{array}$ \\
\hline \multirow[t]{2}{*}{ Ever married } & 43.91 & 45.96 & 47.52 & 45.99 & 13.10 & 15.28 & 13.11 & 15.62 \\
\hline & $(0.60)$ & $(0.21)$ & $(1.06)$ & $(0.55)$ & $(0.36)$ & $(0.13)$ & $(0.51)$ & $(0.37)$ \\
\hline \multirow{2}{*}{$\begin{array}{l}\text { Ever attended } \\
\text { secondary } \\
\text { school }\end{array}$} & 73.71 & 76.76 & 31.90 & 27.44 & 68.09 & 82.49 & 54.36 & 28.24 \\
\hline & $(0.76)$ & $(0.22)$ & $(1.46)$ & $(0.54)$ & $(0.94)$ & $(0.41)$ & (1.80) & $(0.82)$ \\
\hline \multirow{4}{*}{$\begin{array}{l}\text { Median years } \\
\text { of schooling } \\
\text { (in number of } \\
\text { years) } \\
\text { Currently in } \\
\text { school }\end{array}$} & 9.16 & 8.76 & 4.00 & 4.72 & 7.69 & 8.76 & 7.28 & 5.33 \\
\hline & $(0.02)$ & $(0.01)$ & $(0.10)$ & $(0.03)$ & $(0.03)$ & $(0.02)$ & $(0.04)$ & $(0.03)$ \\
\hline & 22.71 & 24.16 & 12.59 & 19.31 & 19.00 & 27.92 & 24.20 & 18.24 \\
\hline & $(0.56)$ & $(0.34)$ & $(0.75)$ & $(0.44)$ & (0.69) & (0.38) & (1.13) & $(0.68)$ \\
\hline \multirow{2}{*}{$\begin{array}{l}\text { Currently } \\
\text { employed }\end{array}$} & 24.15 & 13.29 & 34.34 & 35.37 & 54.09 & 42.33 & 48.28 & 54.12 \\
\hline & $(0.63)$ & $(0.31)$ & $(0.95)$ & $(0.59)$ & (1.02) & $(0.48)$ & (1.37) & $(0.92)$ \\
\hline \multirow[t]{2}{*}{$\begin{array}{l}\text { In school and } \\
\text { employed }\end{array}$} & 5.22 & 2.80 & 3.51 & 6.08 & 16.69 & 5.95 & 11.47 & 21.64 \\
\hline & $(0.28)$ & $(0.14)$ & $(0.26)$ & $(0.24)$ & $(0.65)$ & $(0.22)$ & $(0.80)$ & $(0.88)$ \\
\hline \multirow[t]{2}{*}{$\begin{array}{l}\text { On-farm: } \\
\text { Works for self* }\end{array}$} & 2.99 & 9.43 & 13.73 & 18.46 & & & & \\
\hline & $(0.36)$ & $(0.45)$ & (1.13) & $(0.49)$ & & & & \\
\hline \multirow{2}{*}{$\begin{array}{l}\text { On-farm: } \\
\text { Works for } \\
\text { family } \\
\text { member }\end{array}$} & 22.20 & 44.80 & 11.87 & 29.03 & & & & \\
\hline & (1.39) & $(0.94)$ & (1.03) & $(0.83)$ & & & & \\
\hline \multirow{2}{*}{$\begin{array}{l}\text { On-farm: } \\
\text { Works for } \\
\text { someone else* }\end{array}$} & 3.62 & 6.05 & 4.21 & 4.19 & & & & \\
\hline & $(0.35)$ & $(0.36)$ & $(0.90)$ & $(0.22)$ & & & & \\
\hline
\end{tabular}




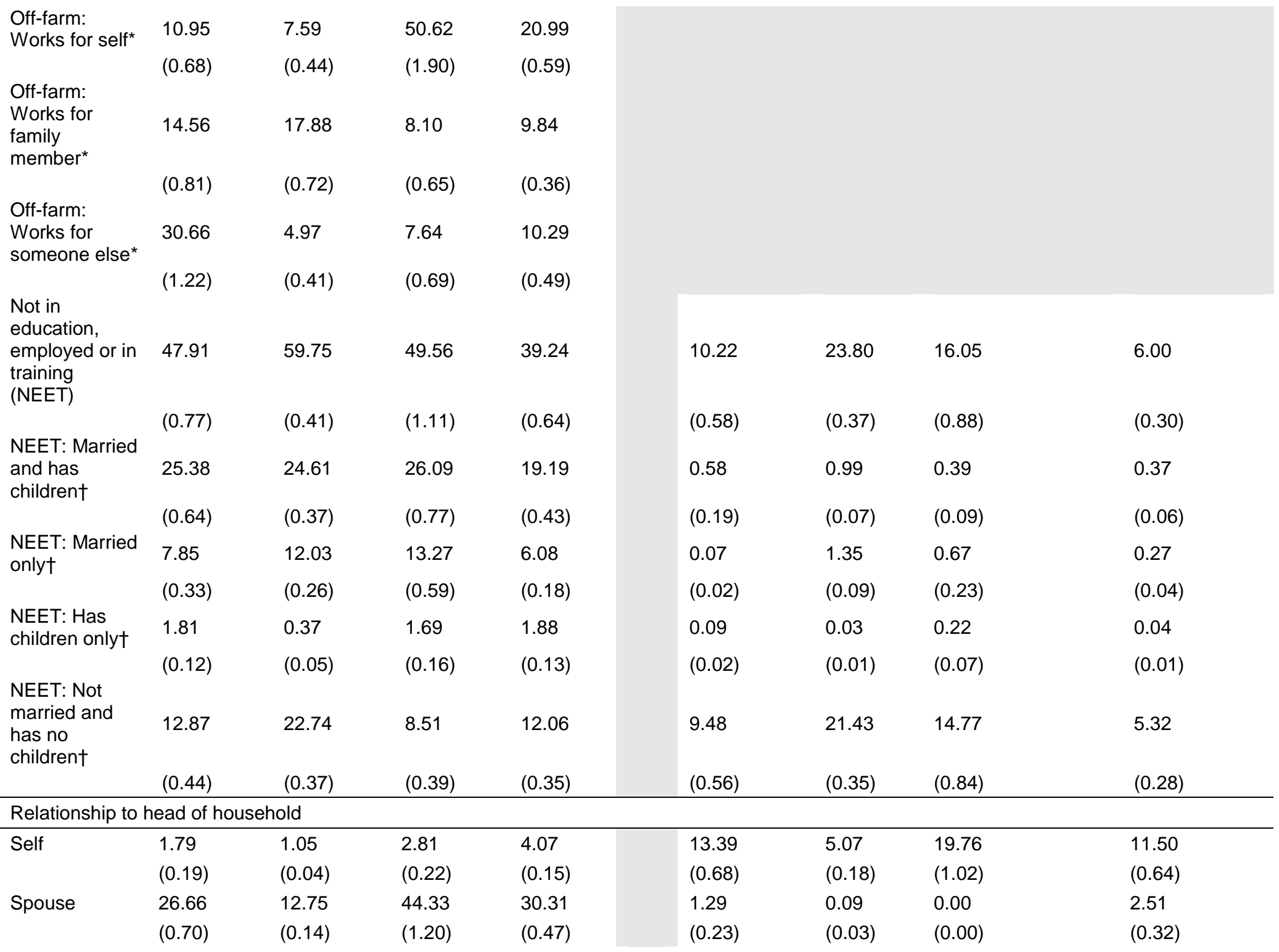




\begin{tabular}{|c|c|c|c|c|c|c|c|c|}
\hline \multirow[t]{2}{*}{ Child } & 50.79 & 52.56 & 26.57 & 44.56 & 63.81 & 78.98 & 63.73 & 71.46 \\
\hline & $(0.79)$ & $(0.20)$ & $(0.87)$ & $(0.52)$ & $(0.96)$ & $(0.40)$ & $(1.14)$ & $(0.79)$ \\
\hline \multirow[t]{2}{*}{ Child-in-law } & 9.17 & 21.50 & 14.75 & 8.25 & 5.62 & 0.40 & 0.29 & 1.03 \\
\hline & $(0.38)$ & $(0.15)$ & $(0.90)$ & $(0.24)$ & $(0.67)$ & $(0.05)$ & $(0.11)$ & $(0.12)$ \\
\hline \multirow[t]{2}{*}{ Other } & 11.60 & 12.13 & 11.55 & 12.81 & 15.89 & 15.47 & 16.22 & 13.49 \\
\hline & $(0.41)$ & $(0.13)$ & $(0.50)$ & $(0.28)$ & $(0.62)$ & $(0.35)$ & $(0.82)$ & $(0.49)$ \\
\hline \multicolumn{9}{|c|}{ Land and house ownership } \\
\hline \multirow[t]{2}{*}{$\begin{array}{l}\text { Owns land } \\
\text { (any } \\
\text { ownership) }\end{array}$} & 11.77 & 24.64 & 8.55 & 26.21 & 12.30 & 38.73 & 20.06 & 20.20 \\
\hline & $(0.46)$ & $(0.48)$ & $(0.45)$ & $(0.49)$ & $(0.63)$ & $(0.67)$ & $(1.32)$ & $(0.82)$ \\
\hline \multirow{2}{*}{$\begin{array}{l}\text { Owns land } \\
\text { solely only }\end{array}$} & 3.22 & 4.25 & 2.47 & 7.21 & 6.66 & 13.08 & 11.59 & 11.69 \\
\hline & $(0.27)$ & $(0.21)$ & $(0.22)$ & $(0.24)$ & $(0.41)$ & $(0.43)$ & $(0.71)$ & $(0.71)$ \\
\hline \multirow[t]{2}{*}{$\begin{array}{l}\text { Owns land } \\
\text { jointly only }\end{array}$} & 7.59 & 11.20 & 4.50 & 16.99 & 3.93 & 15.06 & 7.49 & 7.33 \\
\hline & $(0.38)$ & $(0.29)$ & $(0.29)$ & $(0.43)$ & $(0.43)$ & $(0.46)$ & (1.03) & $(0.42)$ \\
\hline \multirow{2}{*}{$\begin{array}{l}\text { Owns land } \\
\text { solely and } \\
\text { jointly }\end{array}$} & 0.97 & 9.20 & 1.58 & 2.02 & 1.71 & 10.59 & 0.98 & 1.18 \\
\hline & $(0.10)$ & $(0.29)$ & $(0.23)$ & $(0.12)$ & $(0.20)$ & $(0.40)$ & $(0.23)$ & $(0.12)$ \\
\hline \multirow[t]{2}{*}{$\begin{array}{l}\text { Owns house } \\
\text { (any } \\
\text { ownership) }\end{array}$} & 14.11 & 29.51 & 12.33 & 29.47 & 12.24 & 46.64 & 27.97 & 19.82 \\
\hline & $(0.47)$ & $(0.51)$ & $(0.66)$ & $(0.52)$ & $(0.66)$ & $(0.71)$ & $(1.60)$ & $(0.75)$ \\
\hline \multirow{2}{*}{$\begin{array}{l}\text { Owns house } \\
\text { solely only }\end{array}$} & 2.58 & 5.56 & 1.91 & 6.09 & 4.38 & 17.43 & 10.37 & 11.66 \\
\hline & $(0.23)$ & $(0.23)$ & $(0.21)$ & $(0.26)$ & $(0.41)$ & $(0.52)$ & $(0.77)$ & $(0.61)$ \\
\hline \multirow{2}{*}{$\begin{array}{l}\text { Owns house } \\
\text { jointly only }\end{array}$} & 10.28 & 13.85 & 8.65 & 21.05 & 4.89 & 16.72 & 15.18 & 7.02 \\
\hline & $(0.42)$ & $(0.33)$ & $(0.56)$ & $(0.49)$ & $(0.46)$ & $(0.49)$ & (1.35) & $(0.40)$ \\
\hline \multirow{2}{*}{$\begin{array}{l}\text { Owns house } \\
\text { solely and } \\
\text { jointly }\end{array}$} & 1.26 & 10.10 & 1.78 & 2.33 & 2.98 & 12.49 & 2.42 & 1.14 \\
\hline & $(0.11)$ & $(0.30)$ & $(0.26)$ & $(0.13)$ & $(0.27)$ & $(0.43)$ & $(0.40)$ & $(0.16)$ \\
\hline $\mathrm{N}$ & 30433 & 40599 & 17253 & 63952 & 9122 & 30133 & 6138 & 24775 \\
\hline
\end{tabular}


Notes:

Source: Authors' computations from Demographic and Health Surveys post-2010

Estimates are weighted means for the 15-24-year-old population, with corresponding clustered standard errors in parentheses

Countries are classified as follows: High-High (Colombia, Dominican Republic, Egypt (Arab Rep.), Ghana, Guatemala, Honduras, Indonesia, Kyrgyz Republic, Namibia, Peru, Philippines); High-Low

(Bangladesh, Cameroon, Gambia, India, Lesotho, Senegal, Zambia); Low-High (Cote d'Ivoire, Chad, Nigeria, Pakistan, Tajikistan); Low-Low (Afghanistan, Benin, Burkina Faso, Burundi, Cambodia,

Ethiopia, Guinea, Kenya, Mali, Malawi, Mozambique, Myanmar, Nepal, Niger, Rwanda, Sierra Leone, Tanzania, Togo, Uganda)

Marital status estimates are calculated using the household member roster. Data are missing for Bangladesh, Honduras and Kenya

Due to missing data on men for Bangladesh, Peru, Philippines and Tajikistan, these countries are excluded from the calculations, excluding never-married estimates, for both men and women

Data from Burkina Faso, Gambia, Mozambique, Peru and Uganda do not have employment category labels. Therefore, on-farm versus off-farm employment categorization is not available

Colombia does not have data on employer: self, family member or someone else

Indonesia did not ask the question on current school status of household member, so the indicator on whether the household member is still in school was used instead

Philippines does not have data on whether the household member is currently in school, and consequently NEET

${ }^{*}$ Among those employed; data available for female youth only

† Among those who are NEET 
Table 2. Asset ownership among rural youth, by asset type, gender and age group

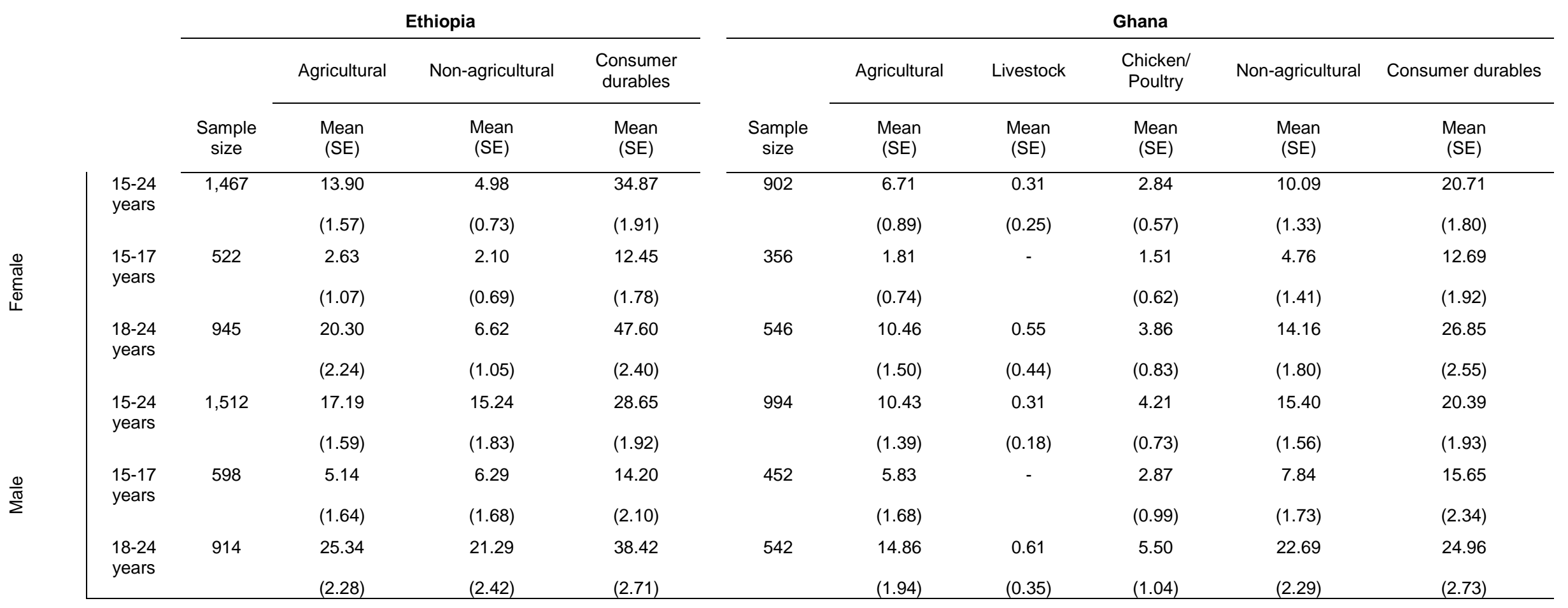

Source: Authors' computations. Estimates are weighted means, with corresponding standard errors clustered at the primary sampling unit level

Data for Ethiopia comes from the 2011/12 Rural Socioeconomic Survey. Data for Ghana comes from the Socioeconomic Panel Survey (2009/10).

Ethiopia agricultural assets are: Axe (gejera), mofer and kember, pickaxe (geso), plough (modern), plough (traditional), sickle (machid), water pump, water storage pit.

Ghana agricultural assets are: two-wheel tractor, four-wheel tractor, Allen key, axe, basket, cane-crusher, canoe, chisel, cutlass, cutter, fishing net, float, hammer, harrow, head-pan, hoe, irrigation pipe,

mattock, nap sack, outboard motor, pickaxe, pincers, pinch bar, plane, plough, plough, pumping machine, rake, saw, screwdriver, scripper, shovel, sickle/reaping hook, spanner, spirit level, spou-shape,

spraying machine, square, tape measure, thread mill, tiller, trailer/cart, trowel, vulcanizing machine, water can, water pump, wellington boots, wheelbarrow.

Non-agricultural assets are: bicycle, cart, hand-pushed or animal-drawn (Ethiopia only), fixed telephone line, mobile phone, motorcycle, sewing machine (Ghana only), weaving machine (Ghana only)

Ethiopia consumer durables are: kerosene, butane gas or electric stove; blanket; mattress or bed; wristwatch or clock; radio/radio and tape/tape; television; CD/VCD/DVD/Video deck; satellite dish; sofa set; electric or power-saving mitad (Ethiopia only); refrigerator; car; jewellery, including gold and silver; wardrobe; shelf for storing goods; biogas stove (pit).

Ghana consumer durables are: 3-in-1 radio system, air conditioner, animal-drawn implements, bag, barrel, basin, bedsheet, blender, book (textbook), bowl, box iron, bucket, buta, camcorder/video camera, camera, carpet/door mat, chainsaw, coal pot, computer accessories, cooking pot, corn mill, cups and plates, cutlery/ utensils, desktop computer, electric power generator, fan, freezer, gallon, game cards (chess, ludo, etc.), glasses, gun, hairdryer, wheelbarrow, head-pan, house, ice-chest, iron (electric), kettle/heater, land (non-farm), lanterns/gas lights, laptop computer, mat/mattress, microwave,

mortar/pestle, motor-driven lawnmower, musical instrument, other sound system, outdoor furniture, parabolic satellite, printer, radio, radio cassette player, record player, refrigerator, room furniture, solar lamp, speaker, stove (electric), stove (gas), stove (kerosene), torch, toy, TV, VCD/DVD player, video player, walking stick, wall clock, washing machine/dryer 
Table 3. Per cent of rural youth who have an identity card, by gender and age group

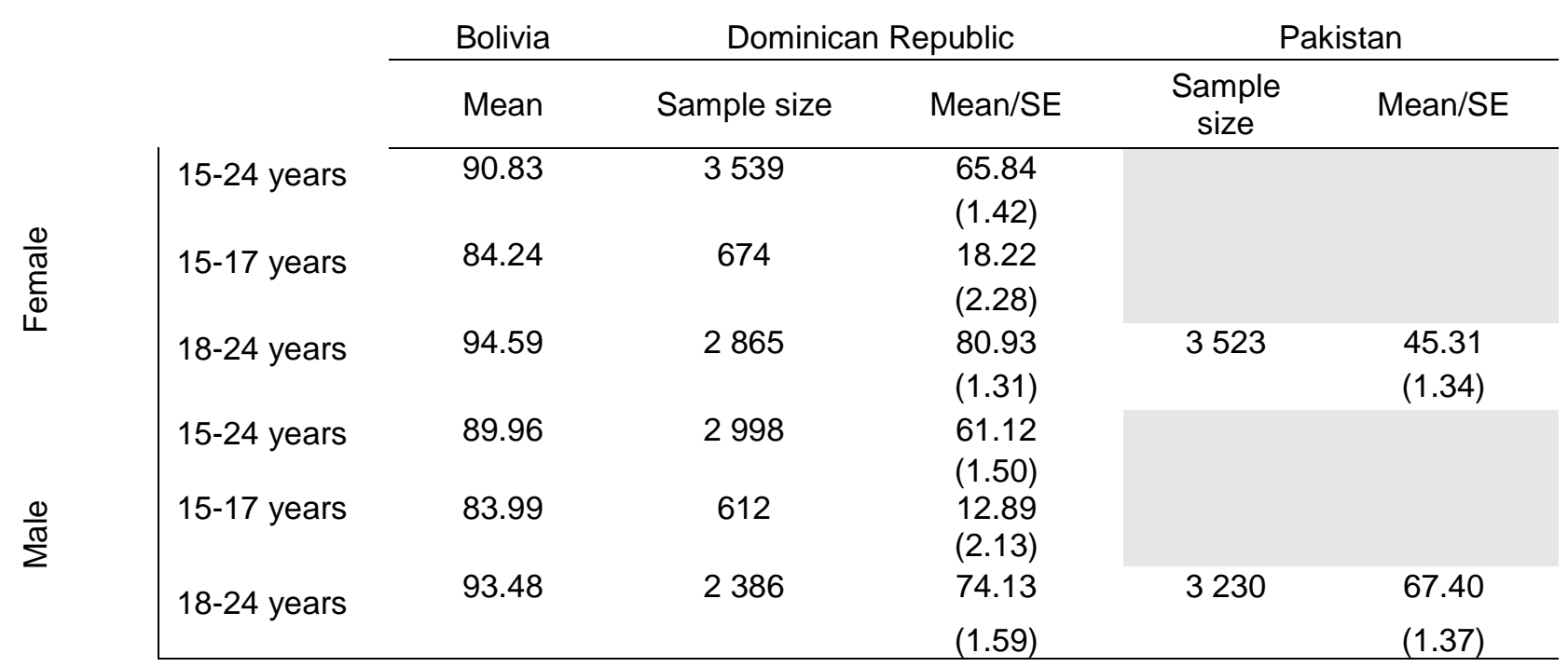

Source: Authors' computations.

Data for Bolivia comes from the 2012 Population and Housing Census

Data for the Dominican Republic comes from the Multiple Indicator Cluster Survey (MICS) in 2014, and represents individuals aged 16 years and over

Data for Pakistan comes from the Demographic and Health Survey in 2012/13, and includes those aged 18 years and over (identity card eligibility age)

Dominican Republic and Pakistan estimates are weighted means, with corresponding standard errors clustered at the primary sampling unit level 


\section{References}

Acevedo, Paloma, Guillermo Cruces, Paul Gertler, and Sebastian Martinez. 2017. "Living Up to Expectations: How Job Training Made Women Better Off and Men Worse Off," NBER Working Paper Series, No. 23264. https://doi.org/10.3386/w23264.

Acharya, Rajib, Abhishek Singh, K. G. Santhya, Faujdar Ram, Shireen Jejeebhoy, Usha Ram, and Sanjay Mohanty. 2010. "Participation in Civil Society and Political Life among Young People in Maharashtra: Findings from the Youth in India - Situation and Needs Study." Journal of Adolescence 33 (4): 553-61. https://doi.org/10.1016/j.adolescence.2009.05.012.

Adoho, Franck, Shubha Chakravarty, Dala T. Korkoyah, Mattias Lundberg, and Afia Tasneem. 2014. "The Impact of an Adolescent Girls Employment Program: The EPAG Project in Liberia." World Bank Policy Research Working Paper, No. 6832. Washington, D.C.: The World Bank. https://doi.org/10.1596/1813-9450-6832.

Aggarwal, Shilpa, and Leora Klapper. 2013. "Designing Government Policies to Expand Financial Inclusion: Evidence from Around the World." Unpublished Working Paper, University of California at Santa Cruz, Santa Cruz CA.

Ahaibwe, Gemma, and Ibrahim Kasirye. 2015. "Creating Youth Employment through Entrepreneurship Financing: The Uganda Youth Venture Capital Fund." Research Series, No. 122. Kampala, Uganda: Economic Policy Research Centre, Makerere University.

Aliero, Haruna Mohammed, and Saifullahi Sani Ibrahim. 2013. "The Challenges of Youth Empowerment through Access to Credit in the Rural Areas of Nigeria." European Journal of Sustainable Development 2 (3): 25-34. https://doi.org/10.14207/ejsd.2013.v2n3p25.

Alzúa, María laura, Guillermo Cruces, and Carolina Lopez. 2016. "Long-Run Effects of Youth Training Programs: Experimental Evidence from Argentina." Economic Inquiry 54 (4): 1839-59. https://doi.org/10.1111/ecin.12348.

Attanasio, Orazio, Arlen Guarin, Carlos Medina, and Costas Meghir. 2017. "Vocational Training for Disadvantaged Youth in Colombia: A Long-Term Follow-Up." American Economic Journal: Applied Economics 9 (2): 131-43. https://doi.org/10.1257/app.20150554.

Baird, Sarah, and Berk Özler. 2016. "Sustained Effects on Economic Empowerment of Interventions for Adolescent Girls: Existing Evidence and Knowledge Gaps." CGD Background Paper. Washington, D.C.: Center for Global Development.

Bandiera, Oriana, Niklas Buehren, Robin Burgess, Markus Goldstein, Selim Gulesci, Imran Rasul, and Munshi Sulaiman. 2017. "Women's Empowerment in Action: Evidence from a Randomized Control Trial in Africa." Washington, D.C.: The World Bank.

Banerjee, Abhijit, Esther Duflo, Nathanael Goldberg, Dean Karlan, Robert Osei, William Parienté, Jeremy Shapiro, Bram Thuysbaert, and Christopher Udry. 2015. "A Multifaceted Program Causes Lasting Progress for the Very Poor: Evidence from Six Countries." Science 348 (6236). https://doi.org/10.1126/science.1260799.

Banks, Nicola. 2015. "What Works for Young People's Development? A Case Study of BRAC's Empowerment and Livelihoods for Adolescent Girls Programme in Uganda and Tanzania." BWPI Working Paper No. 212. Manchester, UK: Brooks World Poverty Institute. 
Bebbington, Anthony. 1999. "Capitals and Capabilities: A Framework for Analyzing Peasant Viability, Rural Livelihoods and Poverty." World Development 27 (12): 2021-44.

Berckmoes, Lidewyde, and Ben White. 2014. "Youth, Farming and Precarity in Rural Burundi." European Journal of Development Research 26 (2): 190-203. https://doi.org/10.1057/ejdr.2013.53.

Blattman, Christopher, Nathan Fiala, and Sebastian Martinez. 2014. "Generating Skilled SelfEmployment in Developing Countries: Experimental Evidence from Uganda." The Quarterly Journal of Economics 129 (2): 697-752. https://doi.org/10.1093/qje/qjt057.

de Brauw, Alan, Daniel O. Gilligan, John Hoddinott, and Shalini Roy. 2015. "The Impact of Bolsa Família on Schooling." World Development 70: 303-16. https://doi.org/10.1016/j.worlddev.2015.02.001.

Brudevold-Newman, Andrew, Maddalena Honorati, Pamela Jakiela, and Owen Ozier. 2017. "A Firm of One's Own Experimental Evidence on Credit Constraints and Occupational Choice." IZA Discussion Paper, No. 10583. Bonn, Germany: IZA - Institute of Labor Economics. https://doi.org/10.1596/1813-9450-7977.

Bryceson, Deborah Fahy. 2002. "The Scramble in Africa: Reorienting Rural Livelihoods." World Development 30 (5): 725-39. https://doi.org/10.1016/S0305-750X(02)00006-2.

Buchmann, Claudia. 2000. "Family Structure, Parental Perceptions, and Child Labor in Kenya: What Factors Determine Who Is Enrolled in School?" Social Forces 78 (4): 1349-78. https://doi.org/10.1093/sf/78.4.1349.

Castellanos, M. Bianet. 2007. "Adolescent Migration to Cancún: Reconfiguring Maya Households and Gender Relations in Mexico's Yucatán Peninsula." Frontiers: A Journal of Women Studies 28 (3): $1-27$.

Chiang, Yi-Lin, Emily C Hannum, and Grace Kao. 2015. "It's Not Just About the Money: Motivations for Youth Migration in Rural China." Chinese Sociological Review 47 (2): 177-201. https://doi.org/10.1080/21620555.2014.990328.

Chigunta, Francis, Jamie Schnurr, David James-Wilson, and Veronica Torres. 2005. "Being 'Real' about Youth Entrepreneurship in Eastern and Southern Africa." SEED Working Paper, No. 72. Geneva: International Labour Office.

Cho, Yoonyoung, Davie Kalomba, Ahmed Mushfiq Mobarak, and Victor Orozco. 2013. "Gender Differences in the Effects of Vocational Training: Constraints on Women and Dropout Behavior." World Bank Policy Research Working Paper, No. 6545. Washington, D.C.: The World Bank. https://doi.org/10.1596/1813-9450-6545.

DFID. 2001. "Sustainable Livelihoods Guidance Sheets." London, UK: Department for International Development.

Doss, Cheryl, Chiara Kovarik, Amber Peterman, Agnes Quisumbing, and Mara van den Bold. 2015. "Gender Inequalities in Ownership and Control of Land in Africa: Myth and Reality." Agricultural Economics 46 (3): 403-34. https://doi.org/10.1111/agec.12171.

Elder, Sara, and Sriani Kring. 2016. "Young and Female - a Double Strike? Gender Analysis of School-to-Work Transition Surveys in 32 Developing Countries." Work4Youth Publication Series, No. 32. Geneva: International Labour Office. 
Fan, C. Cindy. 2003. "Rural-Urban Migration and Gender Division of Labor in Transitional China." International Journal of Urban and Regional Research 27 (1): 24-47. https://doi.org/10.1111/14682427.00429 .

Fares, Jean, Claudio E. Montenegro, and Peter F. Orazem. 2006. "How Are Youth Faring in the Labor Market? Evidence From Around the Word." World Bank Policy Research Working Paper, No. 4071. Washington, D.C.: The World Bank.

Favara, Marta. 2017. "Do Dreams Come True? Aspirations and Educational Attainments of Ethiopian Boys and Girls." Journal of African Economies 26 (5): 561-83. https://doi.org/10.1093/jae/ejx018.

Fiala, Nathan. 2013. "Stimulating Microenterprise Growth: Results from a Loans, Grants and Training Experiment in Uganda." Unpublished Working Paper. International Labour Organization.

Fox, Louise, and Upaasna Kaul. 2018. "The Evidence Is In: How Should Youth Employment Programs In Low-Income Countries Be Designed?" World Bank Policy Research Working Paper, No. 8500. Washington, D.C.: The World Bank. https://doi.org/10.1596/1813-9450-8500.

Gella, Asrat Ayalew, and Getnet Tadele. 2015. "Gender and Farming in Ethiopia: An Exploration of Discourses and Implications for Policy and Research." Ethiopian Journal of the Social Sciences and Humanities 11 (2): 1-28.

Hajdu, Flora, Nicola Ansell, Elsbeth Robson, and Lorraine van Blerk. 2013. "Rural Young People's Opportunities for Employment and Entrepreneurship in Globalised Southern Africa: The Limitations of Targeting Policies." International Development Planning Review 35 (2): 155-74. https://doi.org/10.3828/idpr.2013.11.

Heckert, Jessica. 2015. "New Perspective on Youth Migration: Motives and Family Investment Patterns." Demographic Research 33 (27): 765-800. https://doi.org/10.4054/DemRes.2015.33.27.

Hertrich, Véronique, and Marie Lesclingand. 2012. "Adolescent Migration and the 1990s Nuptiality Transition in Mali." Population Studies 66 (2): 147-66. https://doi.org/10.1080/00324728.2012.669489.

2013. "Adolescent Migration in Rural Africa as a Challenge to Gender and Intergenerational Relationships." The ANNALS of the American Academy of Political and Social Science 648 (1): 175-88. https://doi.org/10.1177/0002716213485356.

Hsin, Amy. 2007. "Children's Time Use, Labor Division, and Schooling In Indonesia" Journal of Marriage and Family 69 (5): 1297-1306. https://doi.org/10.1111/j.1741-3737.2007.00448.x.

ICF. 2010-2016. "Demographic and Health Surveys (Various) [Datasets]." Funded by USAID. Rockville, Maryland: ICF [Distributor].

Instituto Nacional de Estadistics de Bolivia. 2012. "Censo Nacional de Población y Vivienda 2012 (Bolivia Population and Housing Census 2012) [Datasets]." La Paz, Bolivia: Instituto Nacional de Estadistica de Bolivia.

Jensen, Robert. 2012. "Do Labor Market Opportunities Affect Young Women's Work and Family Decisions? Experimental Evidence from India." Quarterly Journal of Economics 127 (2): 753-92. https://doi.org/10.1093/qje/qjs002.

Johnson, Lissa, YungSoo Less, Michael Sherraden, Gina Chowa, David Ansong, Fred Ssewamala, Margaret Sherraden, Moses Njenga, Joseph Kieyah, Sharad Sharma, Jyoti Manandhar, Catherine Rodriguez, Federico Merchán, and Juan Saavedra. 2013. "Youth Savings Patterns and 
Performance in Colombia, Ghana, Kenya, and Nepal." YouthSave Research Brief 13-26. St. Louis, MO: Washington University, Center for Social Development.

Kelley, Donna J., Candida G Brush, Patricia G. Greene, and Yana Litovsky. 2011. "Global Entrepreneurship Monitor: 2010 Women's Report." Babson Park, MA: Babson College.

Keulder, Christiaan, and Dirk Spilker. "In Search of Democrats in Namibia: Attitudes Among the Youth." In Measuring Democracy and Human Rights in Southern Africa, compiled by Henning Melber, Uppsala, Sweden: Nordic Africa Institute, 2002, pp. 19-29.

Kieran, Caitlin, Kathryn Sproule, Agnes Quisumbing, and Cheryl R. Doss. 2017. "Gender Gaps in Land Ownership across and within Households in Four Asian Countries." Land Economics 93 (2): 342-70. https://doi.org/10.3368/le.93.2.342.

Kosec, Katrina, Hosaena Ghebru, Brian Holtemeyer, Valerie Mueller, and Emily Schmidt. 2018. "The Effect of Land Access on Youth Employment and Migration Decisions: Evidence from Rural Ethiopia." American Journal of Agricultural Economics 100 (3): 931-54. https://doi.org/10.1093/ajae/aax087.

Lekalake, Rorisang, and E. Gyimah-Boadi. 2016. "Does Less Engaged Mean Less Empowered? Political Participation Lags among African Youth, Especially Women." Afrobarometer Policy Paper, No. 34.

Maitra, Pushkar, and Subha Mani. 2017. "Learning and Earning: Evidence from a Randomized Evaluation in India." Labour Economics 45: 116-30. https://doi.org/10.1016/j.labeco.2016.11.007.

McKenzie, David. 2008. "A Profile of the World's Young Developing Country International Migrants." Population and Development Review34 (1): 115-35.

Mehta, Anita, and Mukund Chandra Mehta. 2011. "Rural Women Entrepreneurship in India: Opportunities and Challenges." In International Conference on Humanities, Geography and Economics (ICHGE'2011), Pattaya, Thailand.

Meinzen-Dick, Ruth, Nancy Johnson, Agnes Quisumbing, Jemimah Njuki, Julia Behrman, Deborah Rubin, Amber Peterman, and Elizabeth Waithanji. 2011. "Gender, Assets, and Agricultural Development Programs: A Conceptual Framework." CAPRi Working Paper No. 99. Washington, D.C.: International Food Policy Research Institute. https://doi.org/10.2499/CAPRiWP99.

Mel, Suresh de, David McKenzie, and Christopher Woodruff. 2014. "Business Training and Female Enterprise Start-up, Growth, and Dynamics: Experimental Evidence from Sri Lanka." Journal of Development Economics 106: 199-210. https://doi.org/10.1016/j.jdeveco.2013.09.005.

Moya, Jose C. 2007. "Domestic Service in a Global Perspective: Gender, Migration, and Ethnic Niches." Journal of Ethnic and Migration Studies 33 (4): 559-79. https://doi.org/10.1080/13691830701265420.

Mueller, Valerie, Cheryl Doss, and Agnes Quisumbing. 2018. "Youth Migration and Labour Constraints in African Agrarian Households." The Journal of Development Studies 54 (5): 875-94. https://doi.org/10.1080/00220388.2018.1430770.

Mukherjee, Priya. 2017. "The Effects of Social Identity on Aspirations and Learning Outcomes: A Field Experiment in Rural India." Working Paper: S-35120-INC-7. International Growth Center.

Institute National Research Council and Institue of Medicine. 2005. Growing Up Global: The Changing Transitions to Adulthood in Developing Countries. Washington, D.C.: The National Academies Press. https://doi.org/10.17226/11174. 
Oficina Nacional de Estadística (Dominican Republic) and UNICEF. 2014. "Encuesta Nacional de Hogares de Propositos Multiples - Encuesta de Indicadores Múltiples Por Conglomerados (Multiple Indicator Cluster Surveys) 2014 [Datasets]." Santo Domingo, Dominican Republic: Oficina Nacional de Estadística.Palmer, Ransford W. 2009. "The Caribbean Economy: An Overview." In The Caribbean Economy in the Age of Globalization. Early Modern Cultural Studies. New York: Palgrave Macmillan. https://doi.org/10.1057/9780230620902_1.

Porter, Gina, Kate Hampshire, Albert Abane, Augustine Tanle, Kobina Esia-Donkoh, Regina Obilie Amoako-sakyi, Samuel Agblorti, and Samuel Asiedu Owusu. 2011. "Mobility , Education and Livelihood Trajectories for Young People in Rural Ghana: A Gender Perspective." Children's Geographies 9 (3-4): 395-410. https://doi.org/10.1080/14733285.2011.590705.

Quisumbing, Agnes, and Crossley Pinkstaff. 2016. "Keeping Doors Open through Investments in Adolescent Schooling and Nutrition: Lessons from IFPRl's Impact Evaluations." Gender-Nutrition Idea Exchange, Agriculture for Nutrition and Health. 2016.

http://a4nh.cgiar.org/2016/10/05/keeping-doors-open-through-investments-in-adolescentschooling-and-nutrition-lessons-from-ifpris-impact-evaluations/.

Resnick, Danielle, and Daniela Casale. 2011. "The Political Participation of Africa's Youth: Turnout, Partisanship and Protest." Afrobarometer Working Paper, No. 136.

Sykes, Justin, Sara Elder, Yonca Gurbuzer, and Marco Principi. 2016. "Exploring the Linkages between Youth Financial Inclusion and Job Creation: Evidence from the ILO School-to-Work Transition Surveys." Work4Youth Publication Series No. 42. Geneva: International Labour Office.

Vossenberg, Saskia. 2013. "Women Entrepreneurship Promotion in Developing Countries: What Explains the Gender Gap in Entrepreneurship and How to Close It?" Working Paper No. 2013/08. Maastricht: Maastricht School of Management.

White, Simon, and Peter Kenyon. 2007. "Enterprise-Based Youth Employment Policies, Strategies and Programmes: Initiatives for the Development of Enterprise Action and Strategies." Skills Working Paper No. 1. Geneva: International Labour Office. 


\section{Appendices}

Appendix 1. List of papers identified in literature search

\begin{tabular}{|c|c|}
\hline Issue (number of papers) & Papers \\
\hline \multirow{3}{*}{ Education (3) } & (Favara, 2017) \\
\hline & (Mukherjee, 2015) \\
\hline & (Porter et al., 2011) \\
\hline \multirow{4}{*}{$\begin{array}{l}\text { Farm and non-farm } \\
\text { employment (4) }\end{array}$} & (Bryceson, 2002) \\
\hline & $\begin{array}{l}\text { (Fares, Montenegro and Orazem, } \\
2007 \text { ) }\end{array}$ \\
\hline & (Gella and Tadele, 2015) \\
\hline & (Hajdu et al., 2013) \\
\hline \multirow{5}{*}{ Land (5) } & (Berckmoes and White, 2014) \\
\hline & (Doss et al., 2015) \\
\hline & (Kosec et al., 2018) \\
\hline & (Kieran et al., 2017) \\
\hline & (Richards, 2005) \\
\hline \multirow{12}{*}{ Migration (12) } & (Buchmann, 2000) \\
\hline & (Castellanos, 2007) \\
\hline & (Chiang, Hannum and Kao, 2013) \\
\hline & (Fan, 2003) \\
\hline & (Heckert, 2015) \\
\hline & (Hertrich and Lesclingand, 2012) \\
\hline & (Hertrich and Lesclingand, 2013) \\
\hline & (Hsin, 2005) \\
\hline & (McKenzie, 2008) \\
\hline & (Moya, 2007) \\
\hline & $\begin{array}{l}\text { (Mueller, Doss and Quisumbing, } \\
\text { 2018) }\end{array}$ \\
\hline & (Palmer, 2009) \\
\hline
\end{tabular}

\begin{tabular}{|c|c|}
\hline $\begin{array}{c}\text { Issue } \\
\text { (number of } \\
\text { papers) }\end{array}$ & Papers \\
\hline \multirow{5}{*}{$\begin{array}{l}\text { Social and } \\
\text { political capital } \\
\text { (5) }\end{array}$} & (Acharya et al., 2010) \\
\hline & (Banks, 2015) \\
\hline & $\begin{array}{l}\text { (Keulder and Spilker, } \\
\text { 2002) }\end{array}$ \\
\hline & $\begin{array}{l}\text { (Lekalake and Gyimah- } \\
\text { Boadi, 2016) }\end{array}$ \\
\hline & $\begin{array}{l}\text { (Resnick and Casale, } \\
\text { 2011) }\end{array}$ \\
\hline \multirow{11}{*}{$\begin{array}{l}\text { Self-employment } \\
\text { and } \\
\text { entrepreneurship } \\
\text { (10) }\end{array}$} & $\begin{array}{l}\text { (Aggarwal and Klapper, } \\
2013 \text { ) }\end{array}$ \\
\hline & $\begin{array}{l}\text { (Ahaibwe and Kasirye, } \\
\text { 2015) }\end{array}$ \\
\hline & $\begin{array}{l}\text { (Aliero and Ibrahim, } \\
\text { 2013) }\end{array}$ \\
\hline & (Chigunta et al., 2005) \\
\hline & (Elder and Kring, 2016) \\
\hline & (Kelley et al., 2011) \\
\hline & (Johnson et al., 2013) \\
\hline & (Mehta and Mehta, 2011) \\
\hline & (Sykes et al., 2016) \\
\hline & (Vossenberg, 2013) \\
\hline & $\begin{array}{l}\text { (White and Kenyon, } \\
2007 \text { ) }\end{array}$ \\
\hline
\end{tabular}


Appendix 2. Surveys included in analysis, by structural transformation typology and survey year

\begin{tabular}{|c|c|c|c|}
\hline Country & DHS year & Other surveys & Notes \\
\hline \multicolumn{4}{|l|}{ High ST - High RT } \\
\hline Colombia & 2015 & & \\
\hline Dominican Republic & 2013 & $\begin{array}{l}\text { MICS: } 2014 \text { Dominican } \\
\text { Republic Multiple Indicator } \\
\text { Cluster Survey }\end{array}$ & $\begin{array}{l}\text { MICS: Identity card estimates are for youth } \\
\text { aged } 16-24 \text { years }\end{array}$ \\
\hline Egypt & 2014 & & $\begin{array}{l}\text { DHS: Female youth sample only includes } \\
\text { ever-married women; male youth data not } \\
\text { collected }\end{array}$ \\
\hline Ghana & 2014 & $\begin{array}{l}\text { LSMS: } 2009 / 2010 \text { Ghana } \\
\text { Socioeconomic Panel } \\
\text { Survey }\end{array}$ & \\
\hline Guatemala & $2014 / 15$ & & \\
\hline Honduras & $2011 / 12$ & & \\
\hline Indonesia & 2012 & & \\
\hline Kyrgyz Republic & 2012 & & \\
\hline Namibia & 2013 & & \\
\hline Peru & 2012 & & DHS: Male youth data not collected \\
\hline Philippines & 2013 & & $\begin{array}{l}\text { DHS: Male youth data not collected; male } \\
\text { and female data excluded from regional } \\
\text { estimates }\end{array}$ \\
\hline \multicolumn{4}{|l|}{ High ST - Low RT } \\
\hline Bangladesh & 2014 & & $\begin{array}{l}\text { DHS: Female youth sample only includes } \\
\text { ever-married women }\end{array}$ \\
\hline Cameroon & 2011 & & \\
\hline Gambia & 2013 & & \\
\hline India & $2015 / 16$ & & \\
\hline Lesotho & 2014 & & \\
\hline Senegal & 2016 & & \\
\hline Zambia & $2013 / 14$ & & \\
\hline \multicolumn{4}{|l|}{ Low ST - High RT } \\
\hline Chad & $2014 / 15$ & & \\
\hline Cote d'Ivoire & $2011 / 12$ & & \\
\hline Nigeria & 2013 & & \\
\hline Tajikistan & $2012 / 13$ & & $\begin{array}{l}\text { DHS: Female youth sample only includes } \\
\text { ever-married women; estimates also } \\
\text { included for identity cards for youth aged } \\
18-24 \text { years } \\
\text { DHS: Male youth data not collected }\end{array}$ \\
\hline \multicolumn{4}{|l|}{ Low ST - Low RT } \\
\hline Afghanistan & 2015 & & \\
\hline Benin & $2011 / 12$ & & \\
\hline Burkina Faso & 2010 & & \\
\hline Burundi & 2010 & & \\
\hline Cambodia & 2014 & & \\
\hline Ethiopia & 2016 & $\begin{array}{l}\text { LSMS: } 2011 / 12 \text { Ethiopia } \\
\text { Rural Socioeconomic Survey }\end{array}$ & \\
\hline
\end{tabular}




\begin{tabular}{lll}
\multicolumn{1}{c}{ Country } & DHS year & Other surveys \\
Guinea & 2012 & \\
Kenya & 2014 \\
Malawi & $2015 / 16$ \\
Mali & $2012 / 13$ \\
Mozambique & 2011 \\
Myanmar & $2015 / 16$ \\
Nepal & 2016 \\
Niger & 2012 \\
Rwanda & $2014 / 15$ \\
Sierra Leone & 2013 \\
Tanzania & $2015 / 16$ \\
Togo & $2013 / 14$ \\
Uganda & 2011 \\
Source: Authors & \\
DHS: Demographic and Health Survey \\
LSMS: Living Standards Measurement Survey \\
MICS: Multiple Indicator Cluster Survey \\
ST: Structural Transformation; RT: Rural Transformation
\end{tabular}


Appendix 3. Weighted means of select indicators for rural youth aged 15-17 years, by gender and structural transformation typology

Ever married

Ever attended secondary school

Median years of schooling (in number of years)

Currently in school

Currently employed

In school and employed

On-farm: Works for self*

On-farm: Works for family member

On-farm: Works for someone else*

Off-farm: Works for self*

Off-farm: Works for family member $^{*}$

Off-farm: Works for someone else*

Not in education, employed or in training (NEET) NEET: Married and has
children†

NEET: Married only†

NEET: Has children only†

NEET: Not married and has no children†

$\begin{array}{r}7 \\ \hline 8 \\ \hline\end{array}$

Female

\begin{tabular}{ccccc}
$\begin{array}{c}\text { High- } \\
\text { High }\end{array}$ & $\begin{array}{c}\text { High- } \\
\text { Low }\end{array}$ & $\begin{array}{c}\text { Low- } \\
\text { High }\end{array}$ & $\begin{array}{c}\text { Low- } \\
\text { Low }\end{array}$ \\
\cline { 1 - 2 } $\begin{array}{c}\text { Mean } \\
(\mathrm{SE})\end{array}$ & $\begin{array}{c}\text { Mean } \\
\text { (SE) }\end{array}$ & $\begin{array}{c}\text { Mean } \\
(\mathrm{SE})\end{array}$ & $\begin{array}{c}\text { Mean } \\
(\mathrm{SE})\end{array}$ \\
\hline 8.53 & 4.88 & 20.06 & 11.97 \\
$(0.45)$ & $(0.11)$ & $(1.19)$ & $(0.44)$
\end{tabular}

$\begin{array}{llll}79.65 & 84.78 & 37.88 & 27.84\end{array}$

$(0.87) \quad(0.26) \quad(2.01) \quad(0.73)$

$\begin{array}{llll}8.45 & 8.84 & 5.00 & 5.35\end{array}$

$\begin{array}{llll}(0.02) & (0.01) \quad(0.07) \quad(0.03)\end{array}$

$\begin{array}{llll}56.27 & 63.23 & 31.65 & 40.93\end{array}$

$\begin{array}{llll}(1.18) & (0.70) \quad(1.86) \quad(0.84)\end{array}$

$\begin{array}{llll}10.95 & 7.23 & 21.20 & 21.60\end{array}$

$(0.71) \quad(0.39) \quad(1.39) \quad(0.67)$

$\begin{array}{llll}9.44 & 6.94 & 7.63 & 11.71\end{array}$

$\begin{array}{llll}(0.62) & (0.36) \quad(0.65) \quad(0.51)\end{array}$

$\begin{array}{llll}1.68 & 7.91 & 8.91 & 9.66\end{array}$

$(0.32) \quad(0.76) \quad(1.43) \quad(0.56)$

$\begin{array}{llll}29.02 & 51.55 & 15.03 & 37.57\end{array}$

(2.41) (1.47) (1.45) (1.32)

$\begin{array}{llll}4.95 & 7.94 & 3.40 & 4.26\end{array}$

$(0.77) \quad(0.70) \quad(1.48) \quad(0.37)$

$\begin{array}{llll}5.52 & 4.64 & 50.31 & 17.11\end{array}$

$\begin{array}{llll}(1.04) \quad(0.59) \quad(2.66) \quad(0.86) & 0\end{array}$

$20.09 \quad 15.28 \quad 13.80 \quad 13.34$

$(1.74) \quad(1.06) \quad(1.38) \quad(0.67)$

$\begin{array}{llll}26.21 & 4.05 & 4.82 & 9.63\end{array}$

$\begin{array}{llll}(2.48) \quad(0.57) \quad(0.81) \quad(0.80) & 0\end{array}$

$23.35 \quad 22.60 \quad 39.52 \quad 25.77$

$(1.04) \quad(0.58) \quad(1.73) \quad(0.80)$

$\begin{array}{llll}3.33 & 0.99 & 6.50 & 3.20\end{array}$

$\begin{array}{llll}(0.31) & (0.15) \quad(0.64) \quad(0.25)\end{array}$

$\begin{array}{llll}4.14 & 3.15 & 17.22 & 5.49\end{array}$

$\begin{array}{llll}(0.37) & (0.25) \quad(1.17) \quad(0.27)\end{array}$

$\begin{array}{llll}0.47 & 0.05 & 0.91 & 0.95\end{array}$

$\begin{array}{llll}(0.07) \quad(0.01) \quad(0.15) \quad(0.14) & 0\end{array}$

$\begin{array}{llll}15.42 & 18.41 \quad 14.89 & 16.13\end{array}$

$(0.92) \quad(0.54) \quad(0.90) \quad(0.63)$

Relationship to head of household
0.55

0.10

$1.31 \quad 1.09$

\begin{tabular}{cccc}
\multicolumn{4}{c}{ Male } \\
\cline { 1 - 3 } $\begin{array}{c}\text { High- } \\
\text { High }\end{array}$ & $\begin{array}{c}\text { High- } \\
\text { Low }\end{array}$ & $\begin{array}{c}\text { Low- } \\
\text { High }\end{array}$ & $\begin{array}{c}\text { Low- } \\
\text { Low }\end{array}$ \\
\hline $\begin{array}{c}\text { Mean } \\
(\mathrm{SE})\end{array}$ & $\begin{array}{c}\text { Mean } \\
(\mathrm{SE})\end{array}$ & $\begin{array}{c}\text { Mean } \\
(\mathrm{SE})\end{array}$ & $\begin{array}{c}\text { Mean } \\
(\mathrm{SE})\end{array}$ \\
\hline 0.79 & 1.65 & 2.19 & 1.92 \\
$(0.11)$ & $(0.06)$ & $(0.33)$ & $(0.14)$ \\
65.61 & 84.04 & 50.37 & 22.15 \\
$(1.14)$ & $(0.56)$ & $(2.24)$ & $(0.95)$ \\
6.97 & 8.71 & 6.59 & 5.23 \\
$(0.01)$ & $(0.02)$ & $(0.03)$ & $(0.03)$ \\
41.85 & 64.47 & 41.12 & 29.32 \\
$(1.18)$ & $(0.73)$ & $(2.03)$ & $(1.26)$ \\
19.59 & 15.11 & 25.92 & 31.88 \\
$(0.98)$ & $(0.54)$ & $(1.71)$ & $(1.10)$ \\
32.40 & 11.87 & 13.60 & 32.52 \\
$(1.15)$ & $(0.49)$ & $(1.21)$ & $(1.45)$
\end{tabular}

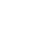




\begin{tabular}{|c|c|c|c|c|c|c|c|c|}
\hline & \multicolumn{4}{|c|}{ Female } & \multicolumn{4}{|c|}{ Male } \\
\hline & $\begin{array}{l}\text { High- } \\
\text { High }\end{array}$ & $\begin{array}{l}\text { High- } \\
\text { Low }\end{array}$ & $\begin{array}{l}\text { Low- } \\
\text { High }\end{array}$ & $\begin{array}{l}\text { Low- } \\
\text { Low }\end{array}$ & $\begin{array}{l}\text { High- } \\
\text { High }\end{array}$ & $\begin{array}{l}\text { High- } \\
\text { Low }\end{array}$ & $\begin{array}{l}\text { Low- } \\
\text { High }\end{array}$ & $\begin{array}{l}\text { Low- } \\
\text { Low }\end{array}$ \\
\hline & $\begin{array}{l}\text { Mean } \\
(\mathrm{SE})\end{array}$ & $\begin{array}{l}\text { Mean } \\
\text { (SE) }\end{array}$ & $\begin{array}{l}\text { Mean } \\
(\mathrm{SE})\end{array}$ & $\begin{array}{l}\text { Mean } \\
\text { (SE) }\end{array}$ & $\begin{array}{l}\text { Mean } \\
\text { (SE) }\end{array}$ & $\begin{array}{l}\text { Mean } \\
(\mathrm{SE})\end{array}$ & $\begin{array}{l}\text { Mean } \\
\text { (SE) }\end{array}$ & $\begin{array}{c}\text { Mean } \\
(\mathrm{SE})\end{array}$ \\
\hline & $(0.27)$ & $(0.01)$ & $(0.26)$ & $(0.14)$ & $(0.19)$ & $(0.06)$ & $(1.00)$ & $(0.22)$ \\
\hline \multirow[t]{2}{*}{ Spouse } & 4.04 & 0.85 & 25.77 & 7.26 & 0.54 & 0.00 & 0.00 & 2.16 \\
\hline & $(0.34)$ & $(0.06)$ & $(1.67)$ & $(0.35)$ & $(0.11)$ & & & $(0.36)$ \\
\hline \multirow[t]{2}{*}{ Child } & 73.94 & 78.15 & 49.58 & 68.95 & 77.55 & 80.69 & 78.53 & 80.33 \\
\hline & $(1.02)$ & $(0.25)$ & $(1.42)$ & $(0.63)$ & $(1.03)$ & $(0.55)$ & $(1.41)$ & $(0.78)$ \\
\hline \multirow[t]{2}{*}{ Child-in-law } & 2.94 & 3.50 & 5.60 & 3.44 & 0.79 & 0.05 & 0.06 & 0.15 \\
\hline & $(0.28)$ & $(0.12)$ & $(0.93)$ & $(0.23)$ & $(0.16)$ & $(0.02)$ & $(0.06)$ & $(0.08)$ \\
\hline \multirow[t]{2}{*}{ Other } & 18.53 & 17.41 & 17.75 & 19.27 & 20.50 & 18.99 & 17.22 & 16.20 \\
\hline & $(0.97)$ & $(0.23)$ & (1.00) & $(0.52)$ & $(1.00)$ & $(0.54)$ & $(1.14)$ & (0.69) \\
\hline \multicolumn{9}{|l|}{ Land and house ownership } \\
\hline \multirow[t]{2}{*}{ Owns land (any ownership) } & 4.71 & 20.66 & 5.56 & 11.73 & 4.59 & 34.43 & 8.44 & 9.72 \\
\hline & $(0.40)$ & $(0.61)$ & $(0.54)$ & $(0.50)$ & $(0.39)$ & $(0.83)$ & $(1.22)$ & $(0.74)$ \\
\hline \multirow[t]{2}{*}{ Owns land solely only } & 1.38 & 3.30 & 1.87 & 3.13 & 1.87 & 10.21 & 3.53 & 4.29 \\
\hline & $(0.22)$ & $(0.27)$ & $(0.32)$ & $(0.21)$ & $(0.24)$ & $(0.52)$ & $(0.56)$ & $(0.54)$ \\
\hline \multirow[t]{2}{*}{ Owns land jointly only } & 2.56 & 9.38 & 2.48 & 7.45 & 0.76 & 13.65 & 4.36 & 4.48 \\
\hline & $(0.31)$ & $(0.41)$ & $(0.32)$ & $(0.42)$ & $(0.13)$ & $(0.57)$ & $(1.04)$ & $(0.52)$ \\
\hline \multirow[t]{2}{*}{ Owns land solely and jointly } & 0.77 & 7.98 & 1.21 & 1.15 & 1.96 & 10.57 & 0.55 & 0.95 \\
\hline & $(0.10)$ & $(0.38)$ & $(0.26)$ & $(0.12)$ & $(0.28)$ & $(0.51)$ & $(0.22)$ & $(0.17)$ \\
\hline \multirow[t]{2}{*}{ Owns house (any ownership) } & 5.93 & 24.49 & 7.46 & 13.11 & 5.11 & 40.52 & 14.65 & 8.63 \\
\hline & $(0.50)$ & $(0.65)$ & $(0.67)$ & $(0.58)$ & $(0.44)$ & $(0.88)$ & $(1.61)$ & $(0.66)$ \\
\hline \multirow[t]{2}{*}{ Owns house solely only } & 0.87 & 4.47 & 1.21 & 2.00 & 0.53 & 13.50 & 1.74 & 2.98 \\
\hline & $(0.22)$ & $(0.31)$ & $(0.34)$ & $(0.18)$ & $(0.11)$ & $(0.61)$ & $(0.35)$ & $(0.37)$ \\
\hline \multirow[t]{2}{*}{ Owns house jointly only } & 3.75 & 11.37 & 5.05 & 9.61 & 1.13 & 14.94 & 10.85 & 4.75 \\
\hline & $(0.40)$ & $(0.44)$ & $(0.53)$ & $(0.52)$ & $(0.16)$ & $(0.59)$ & $(1.51)$ & $(0.50)$ \\
\hline \multirow[t]{2}{*}{$\begin{array}{l}\text { Owns house solely and } \\
\text { jointly }\end{array}$} & 1.32 & 8.64 & 1.20 & 1.50 & 3.45 & 12.08 & 2.06 & 0.89 \\
\hline & $(0.14)$ & $(0.40)$ & $(0.27)$ & $(0.17)$ & $(0.40)$ & $(0.55)$ & $(0.55)$ & $(0.20)$ \\
\hline $\mathrm{N}$ & 10845 & 58522 & 5328 & 20669 & 4594 & 10232 & 2274 & 9160 \\
\hline
\end{tabular}

Source: Authors' estimates from Demographic and Health Surveys post-2010

Estimates are weighted means for the 15-17-year-old population, with corresponding clustered standard errors in parentheses. Countries are classified as follows: High-High (Colombia, Dominican Republic, Egypt (Arab Rep.), Ghana, Guatemala, Honduras, Indonesia, Kyrgyz Republic, Namibia, Peru, Philippines); High-Low (Bangladesh, Cameroon, Gambia, India, Lesotho, Senegal, Zambia); Low-High (Cote d'Ivoire, Chad, Nigeria, Pakistan, Tajikistan); Low-Low (Afghanistan, Benin, Burkina Faso, Burundi, Cambodia, Ethiopia, Guinea, Kenya, Mali, Malawi, Mozambique, Myanmar, Nepal, Niger, Rwanda, Sierra Leone, Tanzania, Togo, Uganda). Marital status estimates are calculated using the household member roster. Data are missing for Bangladesh, Honduras and Kenya. Due to missing data on men for Bangladesh, Peru, Philippines and Tajikistan, these countries are excluded from the calculations, excluding ever-married estimates, for both men and women. Data from Burkina Faso, Gambia, Mozambique, Peru and Uganda do not have employment category labels. Therefore, on-farm versus off-farm employment categorization is not available Colombia does not have data on employer: self, family member or someone else Indonesia did not ask the question on current school status of household member, so the indicator on whether the household member is still in school was used instead

Philippines does not have data on whether the household member is currently in school, and consequently on NEET status

* Among those employed; data available for female youth only

† Among those who are NEET 
Appendix 4. Weighted means of select indicators for rural youth aged 18-24 years, by gender and structural transformation typology

\begin{tabular}{|c|c|c|c|c|c|c|c|c|}
\hline & \multicolumn{4}{|c|}{ Female } & \multicolumn{4}{|c|}{ Male } \\
\hline & High-High & High-Low & Low-High & Low-Low & High-High & High-Low & Low-High & Low-Low \\
\hline & $\begin{array}{c}\text { Mean } \\
\text { (SE) }\end{array}$ & $\begin{array}{c}\text { Mean } \\
\text { (SE) }\end{array}$ & $\begin{array}{c}\text { Mean } \\
\text { (SE) }\end{array}$ & $\begin{array}{c}\text { Mean } \\
\text { (SE) }\end{array}$ & $\begin{array}{c}\text { Mean } \\
\text { (SE) }\end{array}$ & $\begin{array}{c}\text { Mean } \\
(\mathrm{SE})\end{array}$ & $\begin{array}{c}\text { Mean } \\
\text { (SE) }\end{array}$ & $\begin{array}{c}\text { Mean } \\
(\mathrm{SE})\end{array}$ \\
\hline \multirow[t]{2}{*}{ Ever married } & 61.90 & 62.72 & 59.83 & 60.95 & 20.06 & 21.96 & 19.11 & 24.04 \\
\hline & $(0.72)$ & $(0.24)$ & $(1.16)$ & $(0.63)$ & $(0.53)$ & $(0.19)$ & $(0.73)$ & $(0.54)$ \\
\hline \multirow[t]{2}{*}{ Ever attended secondary school } & 70.84 & 73.24 & 29.80 & 27.25 & 68.91 & 81.71 & 56.37 & 31.82 \\
\hline & $(0.90)$ & $(0.25)$ & $(1.42)$ & $(0.58)$ & $(1.12)$ & $(0.47)$ & $(1.93)$ & $(1.02)$ \\
\hline Median years of schooling & 9.26 & 8.71 & 3.69 & 4.21 & 8.51 & 9.75 & 8.71 & 5.94 \\
\hline (in number of years) & $(0.02)$ & $(0.02)$ & $(0.11)$ & $(0.04)$ & $(0.02)$ & $(0.02)$ & $(0.08)$ & $(0.02)$ \\
\hline \multirow{2}{*}{ Currently in school } & 8.45 & 6.81 & 5.89 & 9.25 & 9.70 & 9.49 & 15.70 & 11.72 \\
\hline & $(0.39)$ & $(0.23)$ & $(0.42)$ & $(0.37)$ & $(0.65)$ & $(0.29)$ & $(0.93)$ & $(0.61)$ \\
\hline \multirow[t]{2}{*}{ Currently employed } & 29.85 & 15.98 & 38.96 & 41.78 & 69.19 & 56.05 & 59.50 & 67.22 \\
\hline & $(0.80)$ & $(0.38)$ & $(1.07)$ & $(0.66)$ & (1.15) & $(0.55)$ & (1.49) & $(1.05)$ \\
\hline \multirow[t]{2}{*}{ In school and employed } & 3.31 & 0.97 & 2.05 & 3.46 & 9.50 & 2.97 & 10.40 & 15.23 \\
\hline & $(0.25)$ & $(0.09)$ & $(0.22)$ & $(0.20)$ & $(0.56)$ & $(0.17)$ & $(0.83)$ & $(0.84)$ \\
\hline \multirow[t]{2}{*}{ On-farm: Works for self } & 3.37 & 10.00 & 14.93 & 21.59 & & & & \\
\hline & $(0.43)$ & $(0.45)$ & (1.19) & $(0.57)$ & & & & \\
\hline \multirow[t]{2}{*}{ On-farm: Works for family member } & 20.26 & 44.80 & 11.09 & 25.98 & & & & \\
\hline & $(1.37)$ & $(0.94)$ & $(1.16)$ & $(0.83)$ & & & & \\
\hline \multirow[t]{2}{*}{ On-farm: Works for someone else } & 3.24 & 6.05 & 4.42 & 4.17 & & & & \\
\hline & $(0.36)$ & $(0.36)$ & $(0.85)$ & $(0.25)$ & & & & \\
\hline \multirow[t]{2}{*}{ Off-farm: Works for self } & 12.50 & 7.59 & 50.69 & 22.37 & & & & \\
\hline & $(0.80)$ & $(0.44)$ & $(2.00)$ & $(0.63)$ & & & & \\
\hline \multirow[t]{2}{*}{ Off-farm: Works for family member } & 12.99 & 17.88 & 6.68 & 8.59 & & & & \\
\hline & $(0.90)$ & $(0.72)$ & $(0.69)$ & $(0.36)$ & & & & \\
\hline \multirow[t]{2}{*}{ Off-farm: Works for someone else } & 31.93 & 4.97 & 8.34 & 10.52 & & & & \\
\hline & (1.27) & $(0.41)$ & $(0.79)$ & $(0.50)$ & & & & \\
\hline Not in education, employed or in & 58.38 & 76.24 & 53.09 & 45.51 & 11.61 & 31.49 & 14.40 & 5.84 \\
\hline
\end{tabular}




\begin{tabular}{|c|c|c|c|c|c|c|c|c|c|}
\hline & & \multicolumn{4}{|c|}{ Female } & \multicolumn{4}{|c|}{ Male } \\
\hline & & High-High & High-Low & Low-High & Low-Low & High-High & High-Low & Low-High & Low-Low \\
\hline & \multirow{3}{*}{ training (NEET) } & $\begin{array}{c}\text { Mean } \\
(\mathrm{SE})\end{array}$ & $\begin{array}{c}\text { Mean } \\
(\mathrm{SE})\end{array}$ & $\begin{array}{c}\text { Mean } \\
(\mathrm{SE})\end{array}$ & $\begin{array}{l}\text { Mean } \\
\text { (SE) }\end{array}$ & $\begin{array}{l}\text { Mean } \\
(\mathrm{SE})\end{array}$ & $\begin{array}{c}\text { Mean } \\
(\mathrm{SE})\end{array}$ & $\begin{array}{c}\text { Mean } \\
(\mathrm{SE})\end{array}$ & $\begin{array}{l}\text { Mean } \\
\text { (SE) }\end{array}$ \\
\hline & & & & & & & & & \\
\hline & & $(0.86)$ & $(0.43)$ & $(1.15)$ & $(0.69)$ & $(0.76)$ & $(0.51)$ & $(0.93)$ & $(0.38)$ \\
\hline & \multirow[t]{2}{*}{ NEET: Married and has children† } & 35.19 & 35.09 & 32.99 & 26.62 & 0.86 & 1.49 & 0.59 & 0.59 \\
\hline & & $(0.80)$ & $(0.49)$ & $(0.92)$ & $(0.54)$ & $(0.29)$ & $(0.11)$ & $(0.14)$ & $(0.09)$ \\
\hline & \multirow[t]{2}{*}{ NEET: Married only $\dagger$} & 9.43 & 15.97 & 11.88 & 6.35 & 0.11 & 2.01 & 0.68 & 0.41 \\
\hline & & $(0.44)$ & $(0.35)$ & $(0.62)$ & $(0.23)$ & $(0.03)$ & $(0.14)$ & $(0.22)$ & $(0.07)$ \\
\hline & \multirow[t]{2}{*}{ NEET: Has children only $†$} & 2.41 & 0.52 & 1.96 & 2.31 & 0.12 & 0.05 & 0.33 & 0.06 \\
\hline & & $(0.17)$ & $(0.07)$ & $(0.21)$ & $(0.16)$ & $(0.03)$ & $(0.01)$ & $(0.10)$ & $(0.02)$ \\
\hline & \multirow{2}{*}{$\begin{array}{l}\text { NEET: Not married and has no } \\
\text { childrent }\end{array}$} & 11.36 & 24.66 & 6.27 & 10.16 & 10.53 & 27.94 & 12.79 & 4.78 \\
\hline & & $(0.46)$ & $(0.45)$ & $(0.37)$ & $(0.34)$ & $(0.72)$ & $(0.48)$ & $(0.87)$ & $(0.35)$ \\
\hline \multirow{3}{*}{\multicolumn{2}{|c|}{ Relationship to head of household }} & & & & & & & & \\
\hline & & 2.35 & 1.47 & 3.33 & 5.45 & 19.80 & 7.52 & 27.58 & 17.59 \\
\hline & & $(0.23)$ & $(0.05)$ & $(0.27)$ & $(0.20)$ & $(0.98)$ & $(0.26)$ & $(1.28)$ & $(0.93)$ \\
\hline & \multirow[t]{2}{*}{ Spouse } & 36.82 & 18.00 & 50.86 & 41.02 & 1.67 & 0.13 & 0.01 & 2.71 \\
\hline & & $(0.86)$ & $(0.18)$ & $(1.28)$ & $(0.57)$ & $(0.35)$ & $(0.04)$ & $(0.01)$ & $(0.47)$ \\
\hline & \multirow[t]{2}{*}{ Child } & 40.38 & 41.28 & 18.47 & 33.23 & 56.92 & 78.10 & 56.30 & 66.24 \\
\hline & & $(0.86)$ & $(0.23)$ & $(0.81)$ & $(0.54)$ & $(1.23)$ & $(0.48)$ & (1.33) & $(1.07)$ \\
\hline & \multirow[t]{2}{*}{ Child-in-law } & 11.97 & 29.44 & 17.97 & 10.48 & 8.04 & 0.57 & 0.40 & 1.56 \\
\hline & & $(0.51)$ & $(0.20)$ & $(1.00)$ & $(0.31)$ & $(0.98)$ & $(0.08)$ & $(0.16)$ & $(0.19)$ \\
\hline & \multirow[t]{2}{*}{ Other } & 8.49 & 9.80 & 9.37 & 9.81 & 13.57 & 13.67 & 15.72 & 11.90 \\
\hline & & $(0.39)$ & $(0.13)$ & $(0.50)$ & $(0.28)$ & $(0.74)$ & $(0.39)$ & $(0.92)$ & $(0.58)$ \\
\hline & \multicolumn{9}{|l|}{ Land and house ownership } \\
\hline & \multirow[t]{2}{*}{ Owns land (any ownership) } & 14.91 & 26.43 & 9.60 & 32.89 & 15.99 & 40.89 & 25.89 & 26.37 \\
\hline & & $(0.63)$ & (0.53) & $(0.50)$ & $(0.60)$ & $(0.90)$ & $(0.74)$ & (1.59) & $(1.10)$ \\
\hline & Owns land solely only & 4.00 & 4.68 & 2.68 & 9.08 & 8.87 & 14.52 & 15.63 & 16.05 \\
\hline
\end{tabular}


Female

\begin{tabular}{|c|c|c|c|c|c|c|c|}
\hline High-High & High-Low & Low-High & Low-Low & High-High & High-Low & Low-High & Low-Low \\
\hline $\begin{array}{c}\text { Mean } \\
(\mathrm{SE})\end{array}$ & $\begin{array}{c}\text { Mean } \\
(\mathrm{SE})\end{array}$ & $\begin{array}{l}\text { Mean } \\
(\mathrm{SE})\end{array}$ & $\begin{array}{c}\text { Mean } \\
\text { (SE) }\end{array}$ & $\begin{array}{l}\text { Mean } \\
\text { (SE) }\end{array}$ & $\begin{array}{c}\text { Mean } \\
(\mathrm{SE})\end{array}$ & $\begin{array}{l}\text { Mean } \\
\text { (SE) }\end{array}$ & $\begin{array}{c}\text { Mean } \\
\text { (SE) }\end{array}$ \\
\hline$(0.37)$ & $(0.24)$ & $(0.26)$ & $(0.32)$ & $(0.60)$ & $(0.50)$ & $(1.00)$ & $(0.99)$ \\
\hline 9.77 & 12.01 & 5.21 & 21.38 & 5.41 & 15.78 & 9.06 & 9.01 \\
\hline$(0.51)$ & $(0.33)$ & $(0.34)$ & $(0.51)$ & $(0.63)$ & $(0.52)$ & $(1.13)$ & $(0.49)$ \\
\hline 1.13 & 9.74 & 1.70 & 2.43 & 1.71 & 10.59 & 1.19 & 1.31 \\
\hline$(0.13)$ & $(0.32)$ & $(0.24)$ & $(0.14)$ & $(0.26)$ & $(0.43)$ & $(0.29)$ & $(0.14)$ \\
\hline 17.85 & 31.77 & 14.05 & 37.00 & 15.73 & 49.73 & 34.65 & 26.40 \\
\hline$(0.64)$ & $(0.57)$ & $(0.75)$ & $(0.61)$ & $(0.92)$ & $(0.77)$ & $(1.83)$ & $(1.01)$ \\
\hline 3.32 & 6.05 & 2.15 & 7.97 & 6.28 & 19.41 & 14.70 & 16.78 \\
\hline$(0.32)$ & $(0.27)$ & $(0.23)$ & $(0.35)$ & $(0.60)$ & $(0.60)$ & $(1.09)$ & $(0.91)$ \\
\hline 13.11 & 14.96 & 9.91 & 26.33 & 6.59 & 17.61 & 17.35 & 8.35 \\
\hline$(0.56)$ & $(0.38)$ & $(0.65)$ & $(0.58)$ & $(0.67)$ & $(0.55)$ & (1.49) & $(0.47)$ \\
\hline 1.42 & 10.76 & 1.98 & 2.71 & 2.86 & 12.70 & 2.60 & 1.28 \\
\hline$(0.14)$ & $(0.34)$ & $(0.29)$ & $(0.15)$ & $(0.32)$ & $(0.47)$ & $(0.45)$ & $(0.18)$ \\
\hline 20431 & 130995 & 11940 & 47113 & 6557 & 19905 & 3865 & 15621 \\
\hline
\end{tabular}

Source: Authors' estimates from Demographic and Health Surveys post-2010

Source: Authors' estimates from Demographic and Health Surveys post-2010

Estimates are weighted means for the 15-17-year-old population, with corresponding clustered standard errors in parentheses.
Countries are classified as follows: High-High (Colombia, Dominican Republic, Egypt (Arab Rep.), Ghana, Guatemala, Honduras, Indonesia, Kyrgyz Republic, Namibia, Peru,

Philippines); High-Low (Bangladesh, Cameroon, Gambia, India, Lesotho, Senegal, Zambia); Low-High (Cote d'Ivoire, Chad, Nigeria, Pakistan, Tajikistan); Low-Low (Afghanistan,

Benin, Burkina Faso, Burundi, Cambodia, Ethiopia, Guinea, Kenya, Mali, Malawi, Mozambique, Myanmar, Nepal, Niger, Rwanda, Sierra Leone, Tanzania, Togo, Uganda).

Marital status estimates are calculated using the household member roster. Data are missing for Bangladesh, Honduras and Kenya.

Due to missing data on men for Bangladesh, Peru, Philippines and Tajikistan, these countries are excluded from the calculations, excluding ever-married estimates, for both men and women.

Data from Burkina Faso, Gambia, Mozambique, Peru and Uganda do not have employment category labels. Therefore, on-farm versus off-farm employment categorization is not available.

Colombia does not have data on employer: self, family member or someone else.

Indonesia did not ask the question on current school status of household member, so the indicator on whether the household member is still in school was used instead.

Philippines does not have data on whether the household member is currently in school, and consequently on NEET status.

* Among those employed; data available for female youth only.

${ }^{\dagger}$ Among those who are NEET. 
Appendix 5. Weighted means of "time-trend" country estimates for rural youth aged 15-24 years, by gender

\begin{tabular}{|c|c|c|c|c|c|c|c|c|c|c|c|c|c|c|}
\hline \multirow[t]{2}{*}{$\begin{array}{c}\text { Country } \\
\text { (Year) }\end{array}$} & \multicolumn{2}{|c|}{$\mathrm{N}$} & \multicolumn{2}{|c|}{ Never married } & \multicolumn{2}{|c|}{ Ever married } & \multicolumn{2}{|c|}{$\begin{array}{l}\text { Ever attended } \\
\text { secondary school }\end{array}$} & \multicolumn{2}{|c|}{$\begin{array}{l}\text { Median years of } \\
\text { schooling }\end{array}$} & \multicolumn{2}{|c|}{ Currently employed } & \multicolumn{2}{|c|}{$\begin{array}{l}\text { NEET } \\
\text { (Total) }\end{array}$} \\
\hline & Females & Males & Females & Males & Females & Males & Females & Males & Females & Males & Females & Males & Females & Males \\
\hline $\begin{array}{l}\text { Bangladesh } \\
(1993-94)\end{array}$ & 2851 & 167 & & & & & $\begin{array}{l}16.09 \\
(1.05)\end{array}$ & $\begin{array}{l}20.36 \\
(3.03)\end{array}$ & 0.00 & & $\begin{array}{l}11.40 \\
(0.90)\end{array}$ & $\begin{array}{l}98.43 \\
(1.11)\end{array}$ & $\begin{array}{l}86.74 \\
(0.95)\end{array}$ & $\begin{array}{c}1.57 \\
(1.11)\end{array}$ \\
\hline $\begin{array}{l}\text { Bangladesh } \\
\text { (1996-97) }\end{array}$ & 2575 & 188 & & & & & $\begin{array}{l}21.60 \\
(1.27)\end{array}$ & $\begin{array}{l}17.80 \\
(2.61)\end{array}$ & 1.00 & 0.00 & $\begin{array}{l}30.14 \\
(1.48)\end{array}$ & $\begin{array}{l}96.59 \\
(1.41)\end{array}$ & $\begin{array}{l}66.33 \\
(1.45)\end{array}$ & $\begin{array}{c}2.34 \\
(1.19)\end{array}$ \\
\hline $\begin{array}{l}\text { Bangladesh } \\
(1999-00)\end{array}$ & 2439 & 117 & & & & & $\begin{array}{l}32.07 \\
(1.34)\end{array}$ & $\begin{array}{l}22.46 \\
(3.54)\end{array}$ & 4.00 & 3.00 & $\begin{array}{l}15.83 \\
(1.22)\end{array}$ & $\begin{array}{l}98.60 \\
(1.00)\end{array}$ & $\begin{array}{l}79.95 \\
(1.28)\end{array}$ & $\begin{array}{c}0.82 \\
(0.82)\end{array}$ \\
\hline $\begin{array}{l}\text { Bangladesh } \\
\text { (2004) }\end{array}$ & 2566 & 189 & & & & & $\begin{array}{l}46.52 \\
(1.48)\end{array}$ & $\begin{array}{l}25.84 \\
(3.13)\end{array}$ & 5.00 & 5.00 & $\begin{array}{l}12.78 \\
(0.95)\end{array}$ & $\begin{array}{l}98.66 \\
(0.81)\end{array}$ & $\begin{array}{l}83.68 \\
(1.00)\end{array}$ & $\begin{array}{c}1.34 \\
(0.81)\end{array}$ \\
\hline $\begin{array}{l}\text { Bangladesh } \\
\text { (2007) }\end{array}$ & 2288 & 195 & & & & & $\begin{array}{l}55.82 \\
(1.50)\end{array}$ & $\begin{array}{l}34.21 \\
(3.82)\end{array}$ & 6.00 & 4.00 & $\begin{array}{l}22.89 \\
(1.54)\end{array}$ & $\begin{array}{l}96.98 \\
(1.38)\end{array}$ & $\begin{array}{l}64.55 \\
(1.55)\end{array}$ & $\begin{array}{c}0.81 \\
(0.81)\end{array}$ \\
\hline $\begin{array}{l}\text { Bangladesh } \\
\text { (2011) }\end{array}$ & 2288 & 165 & & & & & $\begin{array}{l}60.47 \\
(1.51)\end{array}$ & $\begin{array}{l}32.25 \\
(4.01)\end{array}$ & 6.00 & 4.00 & $\begin{array}{c}7.41 \\
(0.67)\end{array}$ & $\begin{array}{l}97.23 \\
(1.44)\end{array}$ & $\begin{array}{l}88.98 \\
(0.73)\end{array}$ & $\begin{array}{c}1.03 \\
(0.73)\end{array}$ \\
\hline $\begin{array}{l}\text { Bangladesh } \\
\text { (2014) }\end{array}$ & 3473 & & & & & & $\begin{array}{l}65.14 \\
(1.54)\end{array}$ & & 7.00 & & $\begin{array}{l}22.05 \\
(1.37)\end{array}$ & & $\begin{array}{l}71.72 \\
(1.43)\end{array}$ & \\
\hline $\begin{array}{l}\text { Ghana } \\
(1993)\end{array}$ & 941 & 267 & $\begin{array}{l}40.49 \\
(1.94)\end{array}$ & $\begin{array}{l}84.27 \\
(2.40)\end{array}$ & $\begin{array}{l}59.51 \\
(1.94)\end{array}$ & $\begin{array}{l}15.73 \\
(2.40)\end{array}$ & $\begin{array}{c}5.53 \\
(0.91)\end{array}$ & $\begin{array}{c}9.36 \\
(1.73)\end{array}$ & 6.00 & 8.00 & $\begin{array}{l}57.07 \\
(2.12)\end{array}$ & $\begin{array}{l}56.93 \\
(4.36)\end{array}$ & $\begin{array}{l}28.69 \\
(1.85)\end{array}$ & $\begin{array}{l}19.10 \\
(2.62)\end{array}$ \\
\hline $\begin{array}{l}\text { Ghana } \\
(1998)\end{array}$ & 1168 & 384 & $\begin{array}{l}50.66 \\
(1.76)\end{array}$ & $\begin{array}{l}84.75 \\
(2.02)\end{array}$ & $\begin{array}{l}49.34 \\
(1.76)\end{array}$ & $\begin{array}{l}15.25 \\
(2.02)\end{array}$ & $\begin{array}{l}57.05 \\
(2.17)\end{array}$ & $\begin{array}{l}68.11 \\
(2.77)\end{array}$ & 6.00 & 8.00 & $\begin{array}{l}52.26 \\
(1.76)\end{array}$ & $\begin{array}{l}54.66 \\
(3.08)\end{array}$ & $\begin{array}{l}28.32 \\
(1.52)\end{array}$ & $\begin{array}{l}14.13 \\
(1.89)\end{array}$ \\
\hline $\begin{array}{l}\text { Ghana } \\
(2003)\end{array}$ & 1120 & 1061 & $\begin{array}{l}52.68 \\
(1.89)\end{array}$ & $\begin{array}{l}88.59 \\
(1.16)\end{array}$ & $\begin{array}{l}47.32 \\
(1.89)\end{array}$ & $\begin{array}{l}11.41 \\
(1.16)\end{array}$ & $\begin{array}{l}49.89 \\
(2.30)\end{array}$ & $\begin{array}{l}58.43 \\
(2.35)\end{array}$ & 6.00 & 7.00 & $\begin{array}{l}55.13 \\
(1.85)\end{array}$ & $\begin{array}{l}47.97 \\
(2.19)\end{array}$ & $\begin{array}{l}23.35 \\
(1.65)\end{array}$ & $\begin{array}{l}14.31 \\
(1.30)\end{array}$ \\
\hline $\begin{array}{l}\text { Ghana } \\
(2008)\end{array}$ & 1040 & 948 & $\begin{array}{l}62.67 \\
(1.92)\end{array}$ & $\begin{array}{l}90.73 \\
(1.08)\end{array}$ & $\begin{array}{l}37.33 \\
(1.92)\end{array}$ & $\begin{array}{c}9.27 \\
(1.08)\end{array}$ & $\begin{array}{l}58.85 \\
(2.18)\end{array}$ & $\begin{array}{l}63.15 \\
(2.28)\end{array}$ & 7.00 & 7.00 & $\begin{array}{l}55.32 \\
(1.98)\end{array}$ & $\begin{array}{l}56.94 \\
(2.47)\end{array}$ & $\begin{array}{l}18.74 \\
(1.35)\end{array}$ & $\begin{array}{l}13.26 \\
(1.41)\end{array}$ \\
\hline $\begin{array}{l}\text { Ghana } \\
\text { (2014) }\end{array}$ & 1764 & 833 & $\begin{array}{l}70.03 \\
(1.60)\end{array}$ & $\begin{array}{l}93.33 \\
(0.99)\end{array}$ & $\begin{array}{l}29.97 \\
(1.60)\end{array}$ & $\begin{array}{c}6.67 \\
(0.99)\end{array}$ & $\begin{array}{l}63.57 \\
(2.35)\end{array}$ & $\begin{array}{l}71.83 \\
(2.64)\end{array}$ & 7.00 & 7.00 & $\begin{array}{l}47.79 \\
(1.85)\end{array}$ & $\begin{array}{l}65.72 \\
(2.23)\end{array}$ & $\begin{array}{l}30.78 \\
(1.97)\end{array}$ & $\begin{array}{l}11.68 \\
(1.63)\end{array}$ \\
\hline
\end{tabular}




\begin{tabular}{|c|c|c|c|c|c|c|c|c|c|c|c|c|c|c|}
\hline \multirow[t]{2}{*}{$\begin{array}{l}\text { Country } \\
\text { (Year) }\end{array}$} & \multicolumn{2}{|c|}{$\mathrm{N}$} & \multicolumn{2}{|c|}{ Never married } & \multicolumn{2}{|c|}{ Ever married } & \multicolumn{2}{|c|}{$\begin{array}{l}\text { Ever attended } \\
\text { secondary school }\end{array}$} & \multicolumn{2}{|c|}{$\begin{array}{l}\text { Median years of } \\
\text { schooling }\end{array}$} & \multicolumn{2}{|c|}{ Currently employed } & \multicolumn{2}{|c|}{$\begin{array}{l}\text { NEET } \\
\text { (Total) }\end{array}$} \\
\hline & Females & Males & Females & Males & Females & Males & Females & Males & Females & Males & Females & Males & Females & Males \\
\hline $\begin{array}{l}\text { Bolivia } \\
(1994)\end{array}$ & 1155 & & $\begin{array}{l}61.24 \\
(2.00)\end{array}$ & & $\begin{array}{l}38.76 \\
(2.00)\end{array}$ & & $\begin{array}{l}35.97 \\
(2.55)\end{array}$ & & 5.00 & & $\begin{array}{l}59.51 \\
(2.16)\end{array}$ & & $\begin{array}{l}30.78 \\
(1.90)\end{array}$ & \\
\hline $\begin{array}{l}\text { Bolivia } \\
(1998)\end{array}$ & 1271 & 372 & $\begin{array}{l}57.63 \\
(2.03)\end{array}$ & $\begin{array}{l}79.61 \\
(2.41)\end{array}$ & $\begin{array}{l}42.37 \\
(2.03)\end{array}$ & $\begin{array}{l}20.39 \\
(2.41)\end{array}$ & $\begin{array}{l}37.93 \\
(2.25)\end{array}$ & $\begin{array}{l}63.29 \\
(3.36)\end{array}$ & 5.00 & 7.00 & $\begin{array}{l}42.75 \\
(2.29)\end{array}$ & $\begin{array}{l}69.10 \\
(3.09)\end{array}$ & $\begin{array}{l}43.65 \\
(2.19)\end{array}$ & $\begin{array}{c}8.44 \\
(1.83)\end{array}$ \\
\hline $\begin{array}{l}\text { Bolivia } \\
\text { (2003) }\end{array}$ & 2287 & 728 & $\begin{array}{l}59.61 \\
(1.52)\end{array}$ & $\begin{array}{l}74.55 \\
(1.91)\end{array}$ & $\begin{array}{l}40.39 \\
(1.52)\end{array}$ & $\begin{array}{l}25.45 \\
(1.91)\end{array}$ & $\begin{array}{l}32.34 \\
(2.06)\end{array}$ & $\begin{array}{l}46.59 \\
(2.73)\end{array}$ & 7.00 & 8.00 & $\begin{array}{l}52.36 \\
(2.07)\end{array}$ & $\begin{array}{l}79.51 \\
(2.12)\end{array}$ & $\begin{array}{l}33.00 \\
(1.70)\end{array}$ & $\begin{array}{c}4.74 \\
(1.07)\end{array}$ \\
\hline $\begin{array}{l}\text { Bolivia } \\
(2008)\end{array}$ & 2110 & 625 & $\begin{array}{l}61.69 \\
(1.55)\end{array}$ & $\begin{array}{l}76.62 \\
(2.36)\end{array}$ & $\begin{array}{l}38.31 \\
(1.55)\end{array}$ & $\begin{array}{l}23.38 \\
(2.36)\end{array}$ & $\begin{array}{l}47.26 \\
(1.99)\end{array}$ & $\begin{array}{l}56.75 \\
(2.92)\end{array}$ & 8.00 & 9.00 & $\begin{array}{l}55.95 \\
(2.08)\end{array}$ & $\begin{array}{l}65.35 \\
(2.85)\end{array}$ & $\begin{array}{l}23.75 \\
(1.50)\end{array}$ & $\begin{array}{r}1.33 \\
(0.46)\end{array}$ \\
\hline $\begin{array}{l}\text { Nepal } \\
(2001)\end{array}$ & 2270 & 332 & 0.00 & 0.00 & 100.00 & 100.00 & $\begin{array}{l}19.68 \\
(1.66)\end{array}$ & $\begin{array}{l}46.21 \\
(3.30)\end{array}$ & 0.00 & 5.00 & $\begin{array}{l}75.33 \\
(2.57)\end{array}$ & $\begin{array}{l}94.27 \\
(1.53)\end{array}$ & $\begin{array}{l}23.86 \\
(2.56)\end{array}$ & $\begin{array}{c}1.31 \\
(0.68)\end{array}$ \\
\hline $\begin{array}{l}\text { Nepal } \\
(2006)\end{array}$ & 3250 & 1077 & $\begin{array}{l}43.91 \\
(1.60)\end{array}$ & $\begin{array}{l}68.49 \\
(1.80)\end{array}$ & $\begin{array}{l}56.09 \\
(1.60)\end{array}$ & $\begin{array}{l}31.51 \\
(1.80)\end{array}$ & $\begin{array}{l}44.31 \\
(2.47)\end{array}$ & $\begin{array}{l}66.64 \\
(2.52)\end{array}$ & 5.00 & 7.00 & $\begin{array}{l}64.90 \\
(2.46)\end{array}$ & $\begin{array}{l}74.37 \\
(2.19)\end{array}$ & $\begin{array}{l}22.68 \\
(2.17)\end{array}$ & $\begin{array}{c}4.27 \\
(0.89)\end{array}$ \\
\hline $\begin{array}{l}\text { Nepal } \\
\text { (2011) }\end{array}$ & 3614 & 1131 & $\begin{array}{l}46.81 \\
(1.36)\end{array}$ & $\begin{array}{l}75.65 \\
(1.75)\end{array}$ & $\begin{array}{l}53.19 \\
(1.36)\end{array}$ & $\begin{array}{l}24.35 \\
(1.75)\end{array}$ & $\begin{array}{l}62.61 \\
(2.52)\end{array}$ & $\begin{array}{l}81.51 \\
(1.95)\end{array}$ & 7.00 & 9.00 & $\begin{array}{l}53.19 \\
(2.43)\end{array}$ & $\begin{array}{l}59.84 \\
(2.43)\end{array}$ & $\begin{array}{l}26.77 \\
(2.26)\end{array}$ & $\begin{array}{c}6.66 \\
(0.95)\end{array}$ \\
\hline $\begin{array}{l}\text { Nepal } \\
(2016)\end{array}$ & 1773 & 523 & $\begin{array}{l}41.35 \\
(1.81)\end{array}$ & $\begin{array}{l}73.13 \\
(2.38) \\
\end{array}$ & $\begin{array}{l}58.65 \\
(1.81)\end{array}$ & $\begin{array}{l}26.87 \\
(2.38) \\
\end{array}$ & $\begin{array}{l}66.14 \\
(2.57) \\
\end{array}$ & $\begin{array}{l}77.50 \\
(2.61) \\
\end{array}$ & 8.00 & 9.00 & $\begin{array}{l}49.75 \\
(2.72) \\
\end{array}$ & $\begin{array}{l}59.96 \\
(3.06)\end{array}$ & $\begin{array}{l}34.22 \\
(2.82) \\
\end{array}$ & $\begin{array}{r}12.43 \\
(1.82) \\
\end{array}$ \\
\hline
\end{tabular}

\section{Notes:}

Authors' estimates. Data are from Demographic and Health Surveys for Bolivia, Ghana and Nepal between 1993 and 2016

Estimates are weighted means, with corresponding standard errors clustered at the primary sampling unit level

Bangladesh (all years) and Nepal (2001) samples consist only of ever-married women and men

No male youth data were collected in the Bolivia (1994) survey 
Appendix 6. Weighted means of "time-trend" country estimates for rural youth aged 15-17 years, by gender

\begin{tabular}{|c|c|c|c|c|c|c|c|c|c|c|c|c|c|c|}
\hline \multirow[t]{2}{*}{$\begin{array}{l}\text { Country } \\
\text { (Year) }\end{array}$} & \multicolumn{2}{|c|}{$\mathrm{N}$} & \multicolumn{2}{|c|}{ Never married } & \multicolumn{2}{|c|}{ Ever married } & \multicolumn{2}{|c|}{$\begin{array}{l}\text { Ever attended secondary } \\
\text { school }\end{array}$} & \multicolumn{2}{|c|}{$\begin{array}{l}\text { Median years of } \\
\text { schooling }\end{array}$} & \multicolumn{2}{|c|}{$\begin{array}{l}\text { Currently } \\
\text { employed }\end{array}$} & \multicolumn{2}{|c|}{$\begin{array}{l}\text { NEET } \\
\text { (Total) }\end{array}$} \\
\hline & Females & Males & Females & Males & Females & Males & Females & Males & Females & Males & Females & Males & Females & Males \\
\hline $\begin{array}{l}\text { Bangladesh } \\
(1993-94)\end{array}$ & 718 & & & & & & $\begin{array}{l}13.07 \\
(1.47)\end{array}$ & & 1.00 & & $\begin{array}{c}6.99 \\
(1.04)\end{array}$ & & $\begin{array}{l}89.40 \\
(1.32)\end{array}$ & \\
\hline $\begin{array}{l}\text { Bangladesh } \\
(1996-97)\end{array}$ & 717 & & & & & & $\begin{array}{l}19.68 \\
(1.86)\end{array}$ & & 2.00 & & $\begin{array}{l}21.17 \\
(1.92)\end{array}$ & & $\begin{array}{l}73.58 \\
(1.99)\end{array}$ & \\
\hline $\begin{array}{l}\text { Bangladesh } \\
(1999-00)\end{array}$ & 719 & & & & & & $\begin{array}{l}32.08 \\
(1.91)\end{array}$ & & 4.00 & & $\begin{array}{l}10.54 \\
(1.59)\end{array}$ & & $\begin{array}{l}83.12 \\
(1.83)\end{array}$ & \\
\hline $\begin{array}{l}\text { Bangladesh } \\
\text { (2004) }\end{array}$ & 678 & & & & & & $\begin{array}{l}53.44 \\
(2.44)\end{array}$ & & 5.00 & & $\begin{array}{c}7.76 \\
(1.23)\end{array}$ & & $\begin{array}{l}87.01 \\
(1.54)\end{array}$ & \\
\hline $\begin{array}{l}\text { Bangladesh } \\
\text { (2007) }\end{array}$ & 416 & & & & & & $\begin{array}{l}62.47 \\
(2.97)\end{array}$ & & 6.00 & & $\begin{array}{c}9.88 \\
(1.98)\end{array}$ & & $\begin{array}{l}79.75 \\
(2.53)\end{array}$ & \\
\hline $\begin{array}{l}\text { Bangladesh } \\
\text { (2011) }\end{array}$ & 607 & & & & & & $\begin{array}{l}59.94 \\
(2.67)\end{array}$ & & 6.00 & & $\begin{array}{c}4.89 \\
(1.23)\end{array}$ & & $\begin{array}{l}87.56 \\
(1.58)\end{array}$ & \\
\hline $\begin{array}{l}\text { Bangladesh } \\
\text { (2014) }\end{array}$ & 647 & & & & & & $\begin{array}{l}68.46 \\
(2.49)\end{array}$ & & 7.00 & & $\begin{array}{l}11.24 \\
(1.53)\end{array}$ & & $\begin{array}{l}76.35 \\
(2.23)\end{array}$ & \\
\hline $\begin{array}{l}\text { Ghana } \\
\text { (1993) }\end{array}$ & 253 & & $\begin{array}{l}87.35 \\
(2.11)\end{array}$ & & $\begin{array}{l}12.65 \\
(2.11)\end{array}$ & & $\begin{array}{c}4.35 \\
(1.29)\end{array}$ & & 7.00 & & $\begin{array}{l}30.04 \\
(3.23)\end{array}$ & & $\begin{array}{l}31.23 \\
(3.15)\end{array}$ & \\
\hline $\begin{array}{l}\text { Ghana } \\
\text { (1998) }\end{array}$ & 350 & 147 & $\begin{array}{l}92.48 \\
(1.45)\end{array}$ & $\begin{array}{l}99.21 \\
(0.79)\end{array}$ & $\begin{array}{c}7.52 \\
(1.45)\end{array}$ & $\begin{array}{c}0.79 \\
(0.79)\end{array}$ & $\begin{array}{l}65.05 \\
(3.10)\end{array}$ & $\begin{array}{l}65.39 \\
(4.36)\end{array}$ & 7.00 & 7.00 & $\begin{array}{l}18.65 \\
(2.20)\end{array}$ & $\begin{array}{l}26.08 \\
(3.94)\end{array}$ & $\begin{array}{l}30.26 \\
(2.66)\end{array}$ & $\begin{array}{l}11.52 \\
(2.88)\end{array}$ \\
\hline $\begin{array}{l}\text { Ghana } \\
(2003)\end{array}$ & 349 & 438 & $\begin{array}{l}87.49 \\
(2.00)\end{array}$ & 100.00 & $\begin{array}{l}12.51 \\
(2.00)\end{array}$ & - & $\begin{array}{l}49.16 \\
(3.42)\end{array}$ & $\begin{array}{l}53.80 \\
(2.93)\end{array}$ & 6.00 & 6.00 & $\begin{array}{l}30.67 \\
(3.08)\end{array}$ & $\begin{array}{l}25.79 \\
(2.59)\end{array}$ & $\begin{array}{l}22.18 \\
(2.39)\end{array}$ & $\begin{array}{l}11.20 \\
(1.82)\end{array}$ \\
\hline $\begin{array}{l}\text { Ghana } \\
(2008)\end{array}$ & 353 & 352 & $\begin{array}{l}94.55 \\
(1.62)\end{array}$ & $\begin{array}{l}99.53 \\
(0.47)\end{array}$ & $\begin{array}{c}5.45 \\
(1.62)\end{array}$ & $\begin{array}{c}0.47 \\
(0.47)\end{array}$ & $\begin{array}{l}60.57 \\
(3.20)\end{array}$ & $\begin{array}{l}55.85 \\
(3.22)\end{array}$ & 7.00 & 6.50 & $\begin{array}{l}29.01 \\
(2.97)\end{array}$ & $\begin{array}{l}40.25 \\
(3.87)\end{array}$ & $\begin{array}{l}12.36 \\
(1.86)\end{array}$ & $\begin{array}{l}10.59 \\
(2.00)\end{array}$ \\
\hline $\begin{array}{l}\text { Ghana } \\
(2014)\end{array}$ & 630 & 309 & $\begin{array}{l}96.77 \\
(0.73)\end{array}$ & 100.00 & $\begin{array}{c}3.23 \\
(0.73)\end{array}$ & - & $\begin{array}{l}60.54 \\
(2.76)\end{array}$ & $\begin{array}{l}61.30 \\
(4.10)\end{array}$ & 7.00 & 7.00 & $\begin{array}{l}28.43 \\
(2.52)\end{array}$ & $\begin{array}{l}50.57 \\
(3.99)\end{array}$ & $\begin{array}{l}25.05 \\
(3.02)\end{array}$ & $\begin{array}{l}12.08 \\
(2.39)\end{array}$ \\
\hline
\end{tabular}




\begin{tabular}{|c|c|c|c|c|c|c|c|c|c|c|c|c|c|c|}
\hline \multirow[t]{2}{*}{$\begin{array}{c}\text { Country } \\
\text { (Year) }\end{array}$} & \multicolumn{2}{|c|}{$\mathrm{N}$} & \multicolumn{2}{|c|}{ Never married } & \multicolumn{2}{|c|}{ Ever married } & \multicolumn{2}{|c|}{$\begin{array}{l}\text { Ever attended secondary } \\
\text { school }\end{array}$} & \multicolumn{2}{|c|}{$\begin{array}{l}\text { Median years of } \\
\text { schooling }\end{array}$} & \multicolumn{2}{|c|}{$\begin{array}{l}\text { Currently } \\
\text { employed }\end{array}$} & \multicolumn{2}{|c|}{$\begin{array}{l}\text { NEET } \\
\text { (Total) }\end{array}$} \\
\hline & Females & Males & Females & Males & Females & Males & Females & Males & Females & Males & Females & Males & Females & Males \\
\hline $\begin{array}{l}\text { Bolivia } \\
(1994)\end{array}$ & 421 & & $\begin{array}{l}89.97 \\
(1.61)\end{array}$ & & $\begin{array}{l}10.03 \\
(1.61)\end{array}$ & & $\begin{array}{l}42.48 \\
(3.42)\end{array}$ & & 5.00 & & $\begin{array}{l}51.60 \\
(3.06)\end{array}$ & & $\begin{array}{l}31.04 \\
(2.72)\end{array}$ & \\
\hline $\begin{array}{l}\text { Bolivia } \\
(1998)\end{array}$ & 474 & 166 & $\begin{array}{l}88.45 \\
(1.71)\end{array}$ & $\begin{array}{l}97.50 \\
(1.46)\end{array}$ & $\begin{array}{l}11.55 \\
(1.71)\end{array}$ & $\begin{array}{c}2.50 \\
(1.46)\end{array}$ & $\begin{array}{l}47.43 \\
(3.17)\end{array}$ & $\begin{array}{l}68.66 \\
(4.50)\end{array}$ & 6.00 & 8.00 & $\begin{array}{l}40.88 \\
(3.11)\end{array}$ & $\begin{array}{l}52.13 \\
(4.79)\end{array}$ & $\begin{array}{l}28.62 \\
(2.54)\end{array}$ & $\begin{array}{l}9.06 \\
(3.18)\end{array}$ \\
\hline $\begin{array}{l}\text { Bolivia } \\
\text { (2003) }\end{array}$ & 859 & 279 & $\begin{array}{l}90.73 \\
(1.18)\end{array}$ & $\begin{array}{l}97.84 \\
(0.95)\end{array}$ & $\begin{array}{c}9.27 \\
(1.18)\end{array}$ & $\begin{array}{c}2.16 \\
(0.95)\end{array}$ & $\begin{array}{l}38.15 \\
(3.28)\end{array}$ & $\begin{array}{l}46.45 \\
(3.99)\end{array}$ & 8.00 & 8.00 & $\begin{array}{l}49.32 \\
(2.74)\end{array}$ & $\begin{array}{l}68.83 \\
(3.66)\end{array}$ & $\begin{array}{l}24.96 \\
(2.26)\end{array}$ & $\begin{array}{c}4.36 \\
(1.46)\end{array}$ \\
\hline $\begin{array}{l}\text { Bolivia } \\
\text { (2008) }\end{array}$ & 803 & 279 & $\begin{array}{l}90.69 \\
(1.15)\end{array}$ & $\begin{array}{l}97.34 \\
(1.05)\end{array}$ & $\begin{array}{c}9.31 \\
(1.15)\end{array}$ & $\begin{array}{c}2.66 \\
(1.05)\end{array}$ & $\begin{array}{l}48.72 \\
(2.61)\end{array}$ & $\begin{array}{l}54.59 \\
(4.18)\end{array}$ & 8.00 & 9.00 & $\begin{array}{l}51.03 \\
(2.60)\end{array}$ & $\begin{array}{l}41.51 \\
(3.92)\end{array}$ & $\begin{array}{l}11.21 \\
(1.32)\end{array}$ & $\begin{array}{c}1.47 \\
(0.80)\end{array}$ \\
\hline $\begin{array}{l}\text { Nepal } \\
(2001)\end{array}$ & 351 & & - & & 100.00 & & $\begin{array}{l}19.48 \\
(2.74)\end{array}$ & & - & & $\begin{array}{l}71.50 \\
(4.26)\end{array}$ & & $\begin{array}{l}25.61 \\
(4.17)\end{array}$ & \\
\hline $\begin{array}{l}\text { Nepal } \\
(2006)\end{array}$ & 1119 & 441 & $\begin{array}{l}77.88 \\
(1.68)\end{array}$ & $\begin{array}{l}97.49 \\
(0.74)\end{array}$ & $\begin{array}{l}22.12 \\
(1.68)\end{array}$ & $\begin{array}{c}2.51 \\
(0.74)\end{array}$ & $\begin{array}{l}50.05 \\
(3.19)\end{array}$ & $\begin{array}{l}71.71 \\
(2.93)\end{array}$ & 5.00 & 7.00 & $\begin{array}{l}61.23 \\
(3.11)\end{array}$ & $\begin{array}{l}56.59 \\
(3.73)\end{array}$ & $\begin{array}{l}15.12 \\
(2.62)\end{array}$ & $\begin{array}{c}5.46 \\
(1.35)\end{array}$ \\
\hline $\begin{array}{l}\text { Nepal } \\
(2011)\end{array}$ & 1217 & 433 & $\begin{array}{l}82.93 \\
(1.47)\end{array}$ & $\begin{array}{l}96.84 \\
(1.28)\end{array}$ & $\begin{array}{l}17.07 \\
(1.47)\end{array}$ & $\begin{array}{c}3.16 \\
(1.28)\end{array}$ & $\begin{array}{l}71.90 \\
(2.72)\end{array}$ & $\begin{array}{l}82.26 \\
(3.03)\end{array}$ & 7.00 & 8.00 & $\begin{array}{l}52.38 \\
(2.89)\end{array}$ & $\begin{array}{l}44.35 \\
(3.58)\end{array}$ & $\begin{array}{l}14.09 \\
(2.34)\end{array}$ & $\begin{array}{c}4.68 \\
(1.44)\end{array}$ \\
\hline $\begin{array}{l}\text { Nepal } \\
(2016)\end{array}$ & 598 & 201 & $\begin{array}{l}80.07 \\
(2.47)\end{array}$ & $\begin{array}{l}98.00 \\
(1.31)\end{array}$ & $\begin{array}{l}19.93 \\
(2.47)\end{array}$ & $\begin{array}{c}2.00 \\
(1.31)\end{array}$ & $\begin{array}{l}75.93 \\
(2.62)\end{array}$ & $\begin{array}{l}84.51 \\
(3.17)\end{array}$ & 8.00 & 8.00 & $\begin{array}{l}47.54 \\
(3.11)\end{array}$ & $\begin{array}{l}41.74 \\
(4.49)\end{array}$ & $\begin{array}{l}20.10 \\
(2.83)\end{array}$ & $\begin{array}{c}8.94 \\
(2.82)\end{array}$ \\
\hline
\end{tabular}

Notes:

Authors' estimates.

Data come from Demographic and Health Surveys for Bolivia, Ghana and Nepal between 1993 and 2016.

Estimates are weighted means, with corresponding standard errors clustered at the primary sampling unit level.

Bangladesh (all years) and Nepal (2001) samples consist only of ever-married women and men.

Do male youth data were collected in the Bolivia (1994) survey.

Data for male youth aged 15-17 years for Bangladesh (2004), Ghana (1993) and Nepal (2001) were excluded because of $\mathrm{N}<100$ observations. 
Appendix 7. Weighted means of "time-trend" country estimates for rural youth aged 18-24 years, by gender

\begin{tabular}{|c|c|c|c|c|c|c|c|c|c|c|c|c|c|c|}
\hline \multirow[t]{2}{*}{$\begin{array}{c}\text { Country } \\
\text { (Year) }\end{array}$} & \multicolumn{2}{|c|}{$\mathrm{N}$} & \multicolumn{2}{|c|}{ Never married } & \multicolumn{2}{|c|}{ Ever married } & \multicolumn{2}{|c|}{$\begin{array}{l}\text { Ever attended } \\
\text { secondary school }\end{array}$} & \multicolumn{2}{|c|}{$\begin{array}{l}\text { Median years of } \\
\text { schooling }\end{array}$} & \multicolumn{2}{|c|}{ Currently employed } & \multicolumn{2}{|c|}{$\begin{array}{l}\text { NEET } \\
\text { (Total) }\end{array}$} \\
\hline & Females & Males & Females & Males & Females & Males & Females & Males & Females & Males & Females & Males & $\begin{array}{c}\text { Female } \\
\mathrm{s}\end{array}$ & Males \\
\hline $\begin{array}{l}\text { Bangladesh } \\
\text { (1993-94) }\end{array}$ & 2262 & 162 & & & & & $\begin{array}{l}16.55 \\
(1.12)\end{array}$ & $\begin{array}{l}20.40 \\
(3.09)\end{array}$ & 0.00 & & $\begin{array}{l}12.42 \\
(1.01)\end{array}$ & $\begin{array}{l}98.38 \\
(1.14)\end{array}$ & $\begin{array}{l}86.24 \\
(1.05)\end{array}$ & $\begin{array}{l}1.62 \\
(1.14)\end{array}$ \\
\hline $\begin{array}{l}\text { Bangladesh } \\
(1996-97)\end{array}$ & 1986 & 186 & & & & & $\begin{array}{l}21.86 \\
(1.39)\end{array}$ & $\begin{array}{l}17.99 \\
(2.64)\end{array}$ & 1.00 & 1.00 & $\begin{array}{l}32.66 \\
(1.58)\end{array}$ & $\begin{array}{l}96.56 \\
(1.43)\end{array}$ & $\begin{array}{l}64.19 \\
(1.55)\end{array}$ & $\begin{array}{l}2.36 \\
(1.20)\end{array}$ \\
\hline $\begin{array}{l}\text { Bangladesh } \\
(1999-00)\end{array}$ & 1862 & 115 & & & & & $\begin{array}{l}31.50 \\
(1.48)\end{array}$ & $\begin{array}{l}22.24 \\
(3.56)\end{array}$ & 3.00 & 3.00 & $\begin{array}{l}17.15 \\
(1.33)\end{array}$ & $\begin{array}{l}98.59 \\
(1.01)\end{array}$ & $\begin{array}{l}79.14 \\
(1.38)\end{array}$ & $\begin{array}{l}0.83 \\
(0.82)\end{array}$ \\
\hline $\begin{array}{l}\text { Bangladesh } \\
(2004)\end{array}$ & 1983 & 185 & & & & & $\begin{array}{l}44.23 \\
(1.52)\end{array}$ & $\begin{array}{l}25.38 \\
(3.23)\end{array}$ & 5.00 & 5.00 & $\begin{array}{l}14.04 \\
(1.03)\end{array}$ & $\begin{array}{l}98.63 \\
(0.83)\end{array}$ & $\begin{array}{l}82.86 \\
(1.07)\end{array}$ & $\begin{array}{l}1.37 \\
(0.83)\end{array}$ \\
\hline $\begin{array}{l}\text { Bangladesh } \\
(2007)\end{array}$ & 1872 & 194 & & & & & $\begin{array}{l}54.33 \\
(1.58)\end{array}$ & $\begin{array}{l}33.93 \\
(3.82)\end{array}$ & 6.00 & 4.00 & $\begin{array}{l}25.79 \\
(1.72)\end{array}$ & $\begin{array}{l}96.97 \\
(1.39)\end{array}$ & $\begin{array}{l}61.16 \\
(1.76)\end{array}$ & $\begin{array}{l}0.81 \\
(0.81)\end{array}$ \\
\hline $\begin{array}{l}\text { Bangladesh } \\
(2011)\end{array}$ & 3050 & 162 & & & & & $\begin{array}{l}60.12 \\
(1.54)\end{array}$ & $\begin{array}{l}32.26 \\
(4.08)\end{array}$ & 6.00 & 4.00 & $\begin{array}{c}7.93 \\
(0.72)\end{array}$ & $\begin{array}{l}97.18 \\
(1.47)\end{array}$ & $\begin{array}{l}88.99 \\
(0.77)\end{array}$ & $\begin{array}{l}1.05 \\
(0.75)\end{array}$ \\
\hline $\begin{array}{l}\text { Bangladesh } \\
(2014)\end{array}$ & 2826 & & & & & & $\begin{array}{l}64.44 \\
(1.63)\end{array}$ & & 7.00 & & $\begin{array}{l}24.33 \\
(1.53)\end{array}$ & & $\begin{array}{l}70.75 \\
(1.56)\end{array}$ & \\
\hline $\begin{array}{l}\text { Ghana } \\
\text { (1993) }\end{array}$ & 688 & 169 & $\begin{array}{l}23.26 \\
(1.83)\end{array}$ & $\begin{array}{l}75.15 \\
(3.43)\end{array}$ & $\begin{array}{l}76.74 \\
(1.83)\end{array}$ & $\begin{array}{l}24.85 \\
(3.43)\end{array}$ & $\begin{array}{l}5.96 \\
(1.03)\end{array}$ & $\begin{array}{l}13.61 \\
(2.80)\end{array}$ & 6.00 & 9.00 & $\begin{array}{l}67.01 \\
(2.18)\end{array}$ & $\begin{array}{l}73.37 \\
(4.61)\end{array}$ & $\begin{array}{l}27.76 \\
(2.08)\end{array}$ & $\begin{array}{l}14.79 \\
(3.07)\end{array}$ \\
\hline
\end{tabular}




\begin{tabular}{|c|c|c|c|c|c|c|c|c|c|c|c|c|c|c|}
\hline \multirow[t]{2}{*}{$\begin{array}{c}\text { Country } \\
\text { (Year) }\end{array}$} & \multicolumn{2}{|c|}{$\mathrm{N}$} & \multicolumn{2}{|c|}{ Never married } & \multicolumn{2}{|c|}{ Ever married } & \multicolumn{2}{|c|}{$\begin{array}{c}\text { Ever attended } \\
\text { secondary school }\end{array}$} & \multicolumn{2}{|c|}{$\begin{array}{l}\text { Median years of } \\
\text { schooling }\end{array}$} & \multicolumn{2}{|c|}{ Currently employed } & \multicolumn{2}{|c|}{$\begin{array}{l}\text { NEET } \\
\text { (Total) }\end{array}$} \\
\hline & Females & Males & Females & Males & Females & Males & Females & Males & Females & Males & Females & Males & $\begin{array}{c}\text { Female } \\
\mathrm{s}\end{array}$ & Males \\
\hline Ghana & 818 & 237 & 32.32 & 75.69 & 67.68 & 24.31 & 53.55 & 69.81 & 5.00 & 9.00 & 66.93 & 72.55 & 27.47 & 15.77 \\
\hline (1998) & & & (1.94) & (2.96) & (1.94) & (2.96) & $(2.42)$ & (3.29) & & & (1.92) & (2.89) & (1.79) & $(2.54)$ \\
\hline Ghana & 771 & 623 & 36.21 & 80.26 & 63.79 & 19.74 & 50.24 & 61.81 & 6.00 & 7.00 & 66.70 & 64.17 & 23.91 & 16.58 \\
\hline (2003) & & & $(2.30)$ & (1.91) & $(2.30)$ & (1.91) & $(2.56)$ & $(2.90)$ & & & $(2.12)$ & $(2.46)$ & (1.97) & (1.91) \\
\hline Ghana & 687 & 596 & 46.86 & 85.67 & 53.14 & 14.33 & 58.00 & 67.36 & 7.00 & 8.00 & 68.38 & 66.55 & 21.91 & 14.80 \\
\hline (2008) & & & $(2.60)$ & (1.65) & $(2.60)$ & (1.65) & $(2.61)$ & $(2.74)$ & & & (2.12) & (2.33) & $(1.74)$ & $(1.72)$ \\
\hline Ghana & 1134 & 524 & 56.59 & 89.44 & 43.41 & 10.56 & 65.09 & 77.97 & 7.00 & 8.00 & 57.55 & 74.52 & 33.66 & 11.45 \\
\hline (2014) & & & (2.09) & (1.53) & (2.09) & (1.53) & (2.99) & $(2.55)$ & & & (2.27) & $(2.55)$ & (2.19) & (2.05) \\
\hline Bolivia & 734 & & 45.11 & & 54.89 & & 32.30 & & 5.00 & & 63.96 & & 30.64 & \\
\hline (1994) & & & $(2.72)$ & & $(2.72)$ & & $(2.72)$ & & & & (2.32) & & $(2.16)$ & \\
\hline Bolivia & 797 & 206 & 39.77 & 64.78 & 60.23 & 35.22 & 32.43 & 58.84 & 5.00 & 7.00 & 43.83 & 83.16 & 52.36 & 7.93 \\
\hline (1998) & & & $(2.37)$ & (3.77) & $(2.37)$ & (3.77) & (2.39) & $(4.26)$ & & & $(2.49)$ & (3.36) & (2.52) & $(2.28)$ \\
\hline Bolivia & 1428 & 449 & 39.48 & 59.65 & 60.52 & 40.35 & 28.59 & 46.68 & 6.00 & 9.00 & 54.33 & 86.35 & 38.20 & 4.99 \\
\hline (2003) & & & (1.81) & $(2.68)$ & $(1.81)$ & (2.68) & (1.94) & $(3.30)$ & & & (2.17) & (1.99) & (1.99) & $(1.29)$ \\
\hline Bolivia & 1307 & 346 & 43.55 & 57.90 & 56.45 & 42.10 & 46.34 & 58.70 & 8.00 & 9.00 & 59.02 & 86.90 & 31.60 & 1.20 \\
\hline (2008) & & & $(2.18)$ & (3.69) & $(2.18)$ & (3.69) & $(2.21)$ & (3.78) & & & $(2.37)$ & $(2.49)$ & $(2.05)$ & $(0.49)$ \\
\hline Nepal & 1919 & 312 & - & - & 100.00 & $\begin{array}{c}100.0 \\
0\end{array}$ & 19.72 & 46.75 & 0.00 & 5.00 & 76.04 & 94.42 & 23.53 & 1.38 \\
\hline
\end{tabular}




\begin{tabular}{|c|c|c|c|c|c|c|c|c|c|c|c|c|c|c|}
\hline \multirow[t]{2}{*}{$\begin{array}{l}\text { Country } \\
\text { (Year) }\end{array}$} & \multicolumn{2}{|c|}{$\mathrm{N}$} & \multicolumn{2}{|c|}{ Never married } & \multicolumn{2}{|c|}{ Ever married } & \multicolumn{2}{|c|}{$\begin{array}{l}\text { Ever attended } \\
\text { secondary school }\end{array}$} & \multicolumn{2}{|c|}{$\begin{array}{l}\text { Median years of } \\
\text { schooling }\end{array}$} & \multicolumn{2}{|c|}{ Currently employed } & \multicolumn{2}{|c|}{$\begin{array}{l}\text { NEET } \\
\text { (Total) }\end{array}$} \\
\hline & Females & Males & Females & Males & Females & Males & Females & Males & Females & Males & Females & Males & $\begin{array}{c}\text { Female } \\
\mathrm{s}\end{array}$ & Males \\
\hline (2001) & & & & & & & $(1.75)$ & (3.30) & & & (2.55) & (1.58) & (2.55) & $(0.72)$ \\
\hline $\begin{array}{l}\text { Nepal } \\
(2006)\end{array}$ & 2131 & 636 & $\begin{array}{l}25.53 \\
(1.64)\end{array}$ & $\begin{array}{l}49.12 \\
(2.33)\end{array}$ & $\begin{array}{l}74.47 \\
(1.64)\end{array}$ & $\begin{array}{l}50.88 \\
(2.33)\end{array}$ & $\begin{array}{l}41.20 \\
(2.48)\end{array}$ & $\begin{array}{l}63.26 \\
(2.87)\end{array}$ & 4.00 & 7.00 & $\begin{array}{l}66.88 \\
(2.41)\end{array}$ & $\begin{array}{l}86.25 \\
(1.73)\end{array}$ & $\begin{array}{l}26.77 \\
(2.19)\end{array}$ & $\begin{array}{c}3.47 \\
(0.88)\end{array}$ \\
\hline $\begin{array}{l}\text { Nepal } \\
(2011)\end{array}$ & 2397 & 698 & $\begin{array}{l}28.56 \\
(1.56)\end{array}$ & $\begin{array}{l}62.44 \\
(2.42)\end{array}$ & $\begin{array}{l}71.44 \\
(1.56)\end{array}$ & $\begin{array}{l}37.56 \\
(2.42)\end{array}$ & $\begin{array}{l}57.92 \\
(2.75)\end{array}$ & $\begin{array}{l}81.04 \\
(1.92)\end{array}$ & 7.00 & 9.00 & $\begin{array}{l}53.60 \\
(2.51)\end{array}$ & $\begin{array}{l}69.50 \\
(2.41)\end{array}$ & $\begin{array}{l}33.18 \\
(2.56)\end{array}$ & $\begin{array}{r}7.89 \\
(1.25)\end{array}$ \\
\hline $\begin{array}{l}\text { Nepal } \\
(2016)\end{array}$ & 1175 & 322 & $\begin{array}{l}22.12 \\
(1.65)\end{array}$ & $\begin{array}{l}57.57 \\
(3.44)\end{array}$ & $\begin{array}{l}77.88 \\
(1.65)\end{array}$ & $\begin{array}{l}42.43 \\
(3.44)\end{array}$ & $\begin{array}{l}61.27 \\
(3.00)\end{array}$ & $\begin{array}{l}73.11 \\
(3.10)\end{array}$ & 8.00 & 9.00 & $\begin{array}{l}50.85 \\
(2.94)\end{array}$ & $\begin{array}{l}71.35 \\
(3.23)\end{array}$ & $\begin{array}{l}41.23 \\
(3.05)\end{array}$ & $\begin{array}{l}14.61 \\
(2.34)\end{array}$ \\
\hline
\end{tabular}

Notes:

Data are from Demographic and Health Surveys for Bolivia, Ghana and Nepal between 1993 and 2016.

Estimates are weighted means, with corresponding standard errors clustered at the primary sampling unit level.

Bangladesh (all years) and Nepal (2001) samples consist only of ever-married women and men.

No male youth data were collected in the Bolivia (1994) survey. 
- The demography of rural youth in developing countries By Guy Stecklov, Ashira Menashe-Oren

- What drives rural youth welfare? The role of spatial, economic, and household factors By Aslihan Arslan, David Tschirley, Eva-Maria Egger

- Youth agrifood system employment in developing countries: a gender-differentiated spatial approach

By Michael Dolislager, Thomas Reardon, Aslihan Arslan, Louise Fox, Saweda Liverpool-Tasie, Christine Sauer, David Tschirley

- Gender, rural youth and structural transformation: Evidence to inform innovative youth programming

By Cheryl Doss, Jessica Heckert, Emily Myers, Audrey Pereira, Agnes Quisumbing

- Rural outh inclusion, empowerment and participation

By Carolina Trivelli, Jorge Morel

- Economic participation of rural youth: what matters?

By Louise Fox

- Landscapes of rural youth opportunity

By James Sumberg, Jordan Chamberlin, Justin Flynn, Dominic Glover and Vicky Johnson

- Rural youth, today and tomorrow

By Ben White

- Climate and jobs for rural young people

By Karen Brooks, Shahnila Dunston, Keith Wiebe, Channing Arndt, Faaiqa Hartley and Richard Robertson

- Rural transformation and the double burden of malnutrition among rural youth in developing countries

By Suneetha Kadiyala, Elisabetta Aurino, Cristina Cirillo, Chittur S. Srinivasan and Giacomo Zanello

- Inclusive finance and rural youth

By Arianna Gasparri, Laura Munoz

- Information and communication technologies and rural youth By Jenny Aker

- Youth access to land, migration and employment opportunities: evidence from sub-Saharan Africa

By Felix Kwame Yeboah, Thomas S. Jayne, Milu Muyanga and Jordan Chamberlin

- Rural youth in the context of fragility and conflict

By Ghassan Baliki, Tilman Brück (Team Leader), Neil T. N. Ferguson and Wolfgang Stojetz

- Rural youth: determinants of migration throughout the world By Alan de Brauw

- The Impact of Migrants' Remittances and Investment on Rural Youth By Manuel Orozco, Mariellen Jewers

- Unlocking the potential of rural youth: the role of policies and institutions By Lauren Phillips, Paola Pereznieto

- Investing in rural youth in the Asia and the Pacific region By Roehlano Briones 
- The rural youth situation in Latin America and the Caribbean By Maia Guiskin, Pablo Yanes, Miguel del Castillo Negrete

- Investing in rural youth in the Near East, North Africa, Europe and Central Asia By Nader Kabbani

- The narrative on rural youth and economic opportunities in Africa: Facts, myths and gaps By Athur Mabiso, Rui Benfica

All publications in the IFAD Research Series can be found at:

https://www.ifad.org/en/web/knowledge/series?mode=search\&catSeries=39130673 



\section{JUIFAD}

International Fund for Agricultural Development Via Paolo di Dono, 44 - 00142 Rome, Italy Tel: +390654591 - Fax: +39065043463 Email: ifad@ifad.org

www.ifad.org

f facebook.com/ifad

(2) instagram.com/ifadnews

in linkedin.com/company/ifad

twitter.com/ifad

youtube.com/user/ifadTV
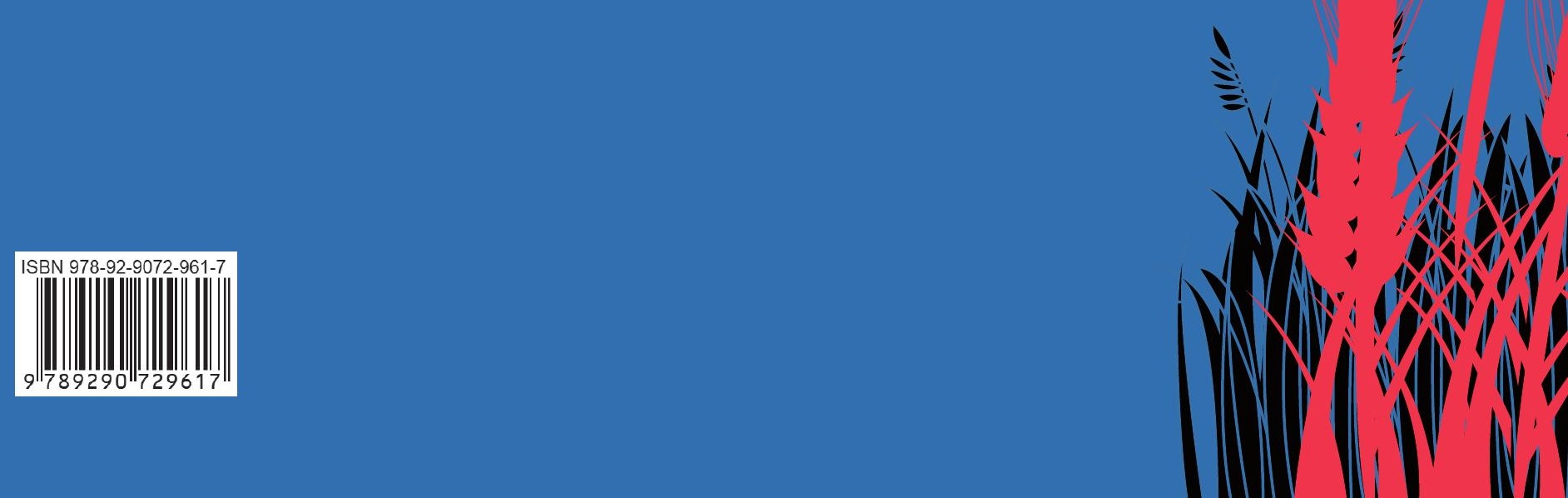